\title{
Re-Analysis of Hydroacoustic Fish-Passage Data from Bonneville Dam after Spill-Discharge Corrections
}

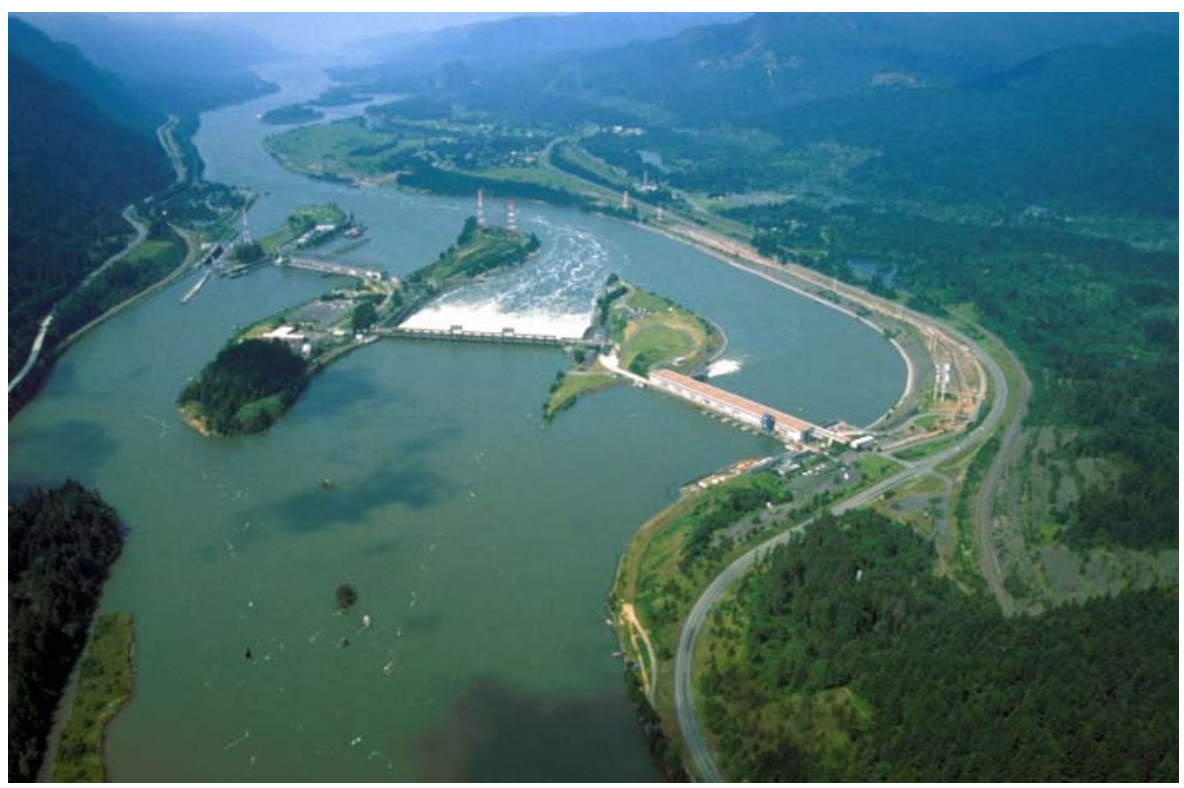

G. R. Ploskey

J. Kim

M.A. Weiland

J.S. Hughes

E.S. Fischer

FINAL REPORT

June 2007

Prepared for the

U.S. Army Corps of Engineers

Under a Related Services Agreement

With the U.S. Department of Energy

Contract DE-AC05-76RLO1830

\section{Pacific Northwest \\ National Laboratory}

Operated by Battelle for the

U.S. Department of Energy 


\title{
DISCLAIMER
}

This report was prepared as an account of work sponsored by an agency of the United States Government. Neither the United States Government nor any agency thereof, nor Battelle Memorial Institute, nor any of their employees, makes any warranty, express or implied, or assumes any legal liability or responsibility for the accuracy, completeness, or usefulness of any information, apparatus, product, or process disclosed, or represents that its use would not infringe privately owned rights. Reference herein to any specific commercial product, process, or service by trade name, trademark, manufacturer, or otherwise does not necessarily constitute or imply its endorsement, recommendation, or favoring by the United States Government or any agency thereof, or Battelle Memorial Institute. The views and opinions of authors expressed herein do not necessarily state or reflect those of the United States Government or any agency thereof.

\author{
PACIFIC NORTHWEST NATIONAL LABORATORY \\ operated by \\ BATTELLE \\ for the
}

UNITED STATES DEPARTMENT OF ENERGY

under Contract DE-AC05-76RL01830

Printed in the United States of America

Available to DOE and DOE contractors from the

Office of Scientific and Technical Information,

P.O. Box 62, Oak Ridge, TN 37831-0062;

ph: (865) 576-8401

fax: (865) 576-5728

email: reports@adonis.osti.gov

Available to the public from the National Technical Information Service,

U.S. Department of Commerce, 5285 Port Royal Rd., Springfield, VA 22161

ph: (800) 553-6847

fax: (703) 605-6900

email: orders@ntis.fedworld.gov

online ordering: http://www.ntis.gov/ordering.htm 


\title{
Re-Analysis of Hydroacoustic Fish-Passage Data from Bonneville Dam after Spill-Discharge Corrections
}

\author{
G. R. Ploskey \\ J. $\operatorname{Kim}^{(a)}$ \\ M. A. Weiland \\ J. S. Hughes \\ E. S. Fischer ${ }^{(a)}$
}

FINAL REPORT

June 2007

Prepared for the U.S. Army Corps of Engineers

Portland District, Portland, Oregon

Under a Related Services Agreement

with the U.S. Department of Energy

Contract DE-AC05-76RL01830

Pacific Northwest National Laboratory

Richland, Washington 99352

(a) Pacific States Marine Fisheries Commission, Portland, Oregon 



\section{Summary}

The Portland District of the U.S. Army Corps of Engineers requested that the Pacific Northwest National Laboratory (PNNL) re-analyze four years of fixed-aspect hydroacoustic data after the District made adjustments to spill discharge estimates that may have been sufficient to alter previous results and conclusions. Results of the 2005 study also are presented in this report. This study supports the Portland District and its effort to maximize survival of juvenile salmon passing Bonneville Dam. Major passage routes through Bonneville Dam include 10 turbines and a sluiceway at Powerhouse 1 (B1), an 18-bay spillway, and eight turbines and a sluiceway at Powerhouse 2 (B2).

In this report, we present new estimates of all major fish-passage metrics for study years 2000, 2001, 2002, and 2004, and reiterate estimates for 2005. No study was conducted in 2003. We also describe relations between spill and sluiceway effectiveness and percent passage by route versus percent flow through the same route. Routes of interest included the spillway, Powerhouse 1 (B1) turbines, Powerhouse 2 (B2) turbines, B1 sluiceway relative to B1, B2 Corner Collector (B2CC) relative to B2, and all non-turbine routes combined (i.e., fish-passage efficiency). For a detailed description of sampling methods by year, we refer readers to the original technical reports (Ploskey et al. 2002a, 2002b, 2003, 2005, and 2006). During the re-analysis, we took the opportunity to adjust spatial expansions of spillway-passed fish to compensate for reduced hydroacoustic detectability that occurs when spill discharge through individual bays increases, something that was done for the first time in the 2006 report on 2005 data.

The original reports and all associated results, discussion, and conclusions for non flow-related metrics remain valid and useful, but effectiveness measures for study years 2000, 2001, 2002, and 2004 as reported in Ploskey et al. (2002a, b; 2003, and 2005) should be superseded with the new estimates for spring (Table S.1) and summer (Table S.2). The only fish-passage metrics that changed more than 3\% from original estimates were related to effectiveness. Re-analysis produced spill effectiveness estimates that ranged from $12 \%$ to $21 \%$ higher than previous estimates in spring and $16.7 \%$ to $27.5 \%$ higher in summer, but the mean spill effectiveness over all years was only slightly above 1:1 (1.17 for spring and 1.29 for summer). While re-analysis increased spill effectiveness, it decreased surface-passage effectiveness in the years that this metric was measured (by $10.1 \%$ in spring and $10.7 \%$ in summer of 2002 and $9.5 \%$ in spring and $10.2 \%$ in summer of 2004). Tight and non-overlapping $95 \%$ confidence limits suggest that original and revised estimates of spill-passage and surface-passage effectiveness were significantly different. Among the smallest changes were in Project fish passage efficiency (FPE) ( $0 \%$ $1 \%)$ and spill efficiency (0.9\%-3.0\%).

The percent of B1 flow into the B1 sluiceway explained $67 \%$ of the variation in B1 sluiceway effectiveness, mostly because the effectiveness of the B1 sluiceway was very high at low flow percentages, something that was not observed for the spillway. The ratio of predicted effectiveness for the B1 sluiceway to that of the spillway was much higher at low percent flow (20:1 at 1\% flow) than it was at very high percent flow (2:1 at $80 \%$ flow). 
Table S.1. Estimates of Major Flow and Passage Metrics for Spring Based on Hydroacoustic Sampling in 2000, 2001, 2002, 2004, and 2005. Headings list some important differences in conditions or sampling among the years. Confidence limits are $\pm 1 / 295 \%$.

\begin{tabular}{|c|c|c|c|c|c|}
\hline Major Passage Metric & $\begin{array}{c}2000 \\
\text { PSC at Units 1-6 } \\
\text { B1 Priority } \\
\text { No Sluiceway } \\
\text { Sampled; } \\
\text { No STS in PSC } \\
\text { STS in 7-10 }\end{array}$ & $\begin{array}{c}2001 \\
\text { Severe Drought; } \\
\text { B2 Priority; } \\
\text { No Sluiceway } \\
\text { Sampled; } \\
\text { B1 Screens } \\
\text { Installed }\end{array}$ & $\begin{array}{c}2002 \\
\text { B2 Priority } \\
\text { B1 Sluiceway } \\
\text { Sampled; } \\
\text { B1 Screens } \\
\text { Installed }\end{array}$ & $\begin{array}{c}2004 \\
\text { B2 Priority } \\
\text { B1 Sluiceway \& } \\
\text { B2CC Sampled } \\
\text { No B1 Screens }\end{array}$ & $\begin{array}{c}2005 \\
\text { B2 Priority } \\
\text { B1 Sluiceway \& } \\
\text { B2CC Sampled } \\
\text { No B1 Screens }\end{array}$ \\
\hline B1 Percent of Project Flow & $37.8 \%$ & $7.5 \%$ & $12.3 \%$ & $12.6 \%$ & $11.6 \%$ \\
\hline B1 Percent of Project Passage & $33.2 \%$ & $6.8 \%$ & $17.9 \%$ & $16.8 \pm 0.9 \%$ & $16.3 \pm 0.6 \%$ \\
\hline Spillway Percent of Project Flow & $31.5 \%$ & $14.7 \%$ & $44.6 \%$ & $33.5 \%$ & $40.3 \%$ \\
\hline Spill Efficiency (Percent of Passage) & $47 \pm 0.1 \%$ & $15.0 \pm 0.2 \%$ & $54.0 \pm 0.5 \%$ & $41.2 \pm 0.9 \%$ & $39.7 \pm 1.1 \%$ \\
\hline B2 Percent of Project Flow & $32.1 \%$ & $78.2 \%$ & $42.6 \%$ & $51 \%$ & $48.2 \%$ \\
\hline B2 Percent of Project Passage & $20.3 \%$ & $78.5 \%$ & $27.9 \%$ & $42.0 \pm 1.2 \%$ & $44.1 \pm 1.6 \%$ \\
\hline Project FPE & $80 \pm 0.1 \%$ & $63 \pm 0.3 \%$ & $79 \pm 0.1 \%$ & $74 \pm 1.2 \%$ & $73.4 \pm 2.0 \%$ \\
\hline B1 FPE (without Sluiceway) & $67 \pm 0.1 \%$ & $49 \pm 2.3 \%$ & $\mathrm{~N} / \mathrm{A}$ & $\mathrm{N} / \mathrm{A}$ & $\mathrm{N} / \mathrm{A}$ \\
\hline B1 FPE (with Sluiceway) & $\mathrm{N} / \mathrm{A}$ & $\mathrm{N} / \mathrm{A}$ & $58 \pm 0.4 \%$ & $33.3 \pm 2.0 \%$ & $37.4 \pm 0.8 \%$ \\
\hline B1 FGE & $67 \pm 0.1 \%$ & $49 \pm 2.3 \%$ & $37 \pm 0.4 \%$ & $\mathrm{~N} / \mathrm{A}$ & $\mathrm{N} / \mathrm{A}$ \\
\hline B2 FGE & $55 \pm 0.1 \%$ & $57 \pm 0.3 \%$ & $53 \pm 0.3 \%$ & $48 \pm 3.3 \%$ & $45.0 \pm 4.3 \%$ \\
\hline B2 FPE (with B2CC) & $\mathrm{N} / \mathrm{A}$ (No B2CC) & N/A (No B2CC) & N/A (No B2CC) & $64.0 \pm 2.1 \%$ & $62.8 \pm 3.9 \%$ \\
\hline FPE (B2 + Spillway) & N/A (B2 Priority) & $64 \pm 0.3 \%$ & $84 \pm 0.1 \%$ & $82 \pm 0.01 \%$ & $80.4 \pm 0.1 \%$ \\
\hline Surface-Passage Efficiency (all) & $N / A$ & N/A & $6.0 \pm 0.1 \%$ & $18.8 \pm 0.4 \%$ & $20.2 \pm 0.6 \%$ \\
\hline Surface Route Percent of Flow & $\mathrm{N} / \mathrm{A}$ & $\mathrm{N} / \mathrm{A}$ & 0.03 & $3.3 \%$ & $3.2 \%$ \\
\hline Project-Wide B1 Sluiceway Efficiency & $\mathrm{N} / \mathrm{A}$ & $\mathrm{N} / \mathrm{A}$ & 5.9 & $5.6 \pm 0.1 \%$ & $6.08 \pm 0.2 \%$ \\
\hline B1 Sluiceway Efficiency (\% of B1) & $N / A$ & $\mathrm{~N} / \mathrm{A}$ & $33.2 \pm 0.9 \%$ & $33.3 \pm 2.0 \%$ & $37.4 \pm 0.8 \%$ \\
\hline Project-Wide B2CC Efficiency & $\mathrm{N} / \mathrm{A}$ & $\mathrm{N} / \mathrm{A}$ & $\mathrm{N} / \mathrm{A}$ & $13.2 \pm 0.3 \%$ & $14.1 \pm 0.4 \%$ \\
\hline B2CC Efficiency (\% of B2) & $\mathrm{N} / \mathrm{A}$ & $\mathrm{N} / \mathrm{A}$ & $\mathrm{N} / \mathrm{A}$ & $31.4 \pm 1.4 \%$ & $31.9 \pm 2.0 \%$ \\
\hline Spill Effectiveness & $1.49 \pm 0.01$ & $1.02 \pm 0.00$ & $1.21 \pm 0.01$ & $1.13 \pm 0.03$ & $0.98 \pm 0.03$ \\
\hline Surface-Passage Effectiveness (all) & $\mathrm{N} / \mathrm{A}$ & $\mathrm{N} / \mathrm{A}$ & $19.7 \pm 0.01$ & $5.7 \pm 0.12$ & $6.3 \pm 0.18$ \\
\hline $\begin{array}{l}\text { Project-Wide B1 Sluiceway } \\
\text { Effectiveness }\end{array}$ & $N / A$ & $\mathrm{~N} / \mathrm{A}$ & $19.7 \pm 0.01$ & $10.1 \pm 0.23$ & $10.7 \pm 0.3$ \\
\hline B1 Sluiceway Effectiveness (Re: B1) & $\mathrm{N} / \mathrm{A}$ & $\mathrm{N} / \mathrm{A}$ & $13.5 \pm 0.06$ & $7.6 \pm 0.5$ & $7.6 \pm 0.2$ \\
\hline Project-Wide B2CC Effectiveness & $\mathrm{N} / \mathrm{A}$ & $\mathrm{N} / \mathrm{A}$ & $N / A$ & $4.8 \pm 0.1$ & $5.3 \pm 0.2$ \\
\hline B2CC Effectiveness (Re: B2) & N/A & $\mathrm{N} / \mathrm{A}$ & $N / A$ & $5.8 \pm 0.03$ & $5.8 \pm 0.4$ \\
\hline
\end{tabular}


Table S.2. Estimates of Major Flow and Passage Metrics for Summer Based upon Hydroacoustic Sampling in 2000, 2001, 2002, 2004, and 2005. Headings list some important differences in conditions or sampling among the years. Confidence limits are $\pm 1 / 295 \%$.

\begin{tabular}{|c|c|c|c|c|c|}
\hline Major Passage Metric & $\begin{array}{c}2000 \\
\text { PSC at Units 1-6 } \\
\text { B1 Priority } \\
\text { No Sluiceway } \\
\text { Sampled; } \\
\text { No STS in PSC } \\
\text { STS in 7-10 }\end{array}$ & $\begin{array}{c}2001 \\
\text { Severe Drought; } \\
\text { B2 Priority; } \\
\text { No Sluiceway } \\
\text { Sampled; } \\
\text { B1 Screens } \\
\text { Installed }\end{array}$ & $\begin{array}{c}2002 \\
\text { B2 Priority } \\
\text { B1 Sluiceway } \\
\text { Sampled; } \\
\text { B1 Screens } \\
\text { Installed }\end{array}$ & $\begin{array}{c}2004 \\
\text { B2 Priority } \\
\text { B1 Sluiceway \& } \\
\text { B2CC Sampled } \\
\text { No B1 Screens }\end{array}$ & $\begin{array}{c}2005 \\
\text { B2 Priority } \\
\text { B1 Sluiceway \& } \\
\text { B2CC Sampled } \\
\text { No B1 Screens }\end{array}$ \\
\hline B1 Percent of Project Flow & $48.9 \%$ & $8.7 \%$ & $22.0 \%$ & $13.5 \%$ & $3.7 \%$ \\
\hline B1 Percent of Project Passage & 40.9 & $7.4 \%$ & $34.7 \%$ & $15.8 \%$ & $7.2 \pm 0.3 \%$ \\
\hline Spillway Percent of Project Flow & $43 \%$ & $9.8 \%$ & $40.2 \%$ & $33.5 \%$ & $51.6 \%$ \\
\hline Spill Efficiency (Percent of Passage) & $52.0 \pm 0.2 \%$ & $22.0 \pm 0.3 \%$ & $45.0 \pm 0.6 \%$ & $34.1 \pm 0.7 \%$ & $44.2 \pm 1.3 \%$ \\
\hline B2 Percent of Project Flow & $10.1 \%$ & $81.7 \%$ & 37.2 & $53.0 \%$ & $44.8 \%$ \\
\hline B2 Percent of Project Passage & $6.8 \%$ & $71.0 \%$ & $19.8 \%$ & $50.1 \pm 0.4 \%$ & $48.6 \pm 1.5 \%$ \\
\hline Project FPE & $80 \pm 0.1 \%$ & $54 \pm 0.4 \%$ & $76 \pm 0.2 \%$ & $71 \pm 1.2 \%$ & $81 \pm 2.1 \%$ \\
\hline B1 FPE (without Sluiceway) & $61 \pm 0.1 \%$ & $40 \pm 1.8 \%$ & $45 \pm 0.5 \%$ & 0 (No STSs) & 0 (No STSs) \\
\hline B1 FPE (with Sluiceway) & $\mathrm{N} / \mathrm{A}$ & N/A & $61 \pm 0.3 \%$ & $37.6 \pm 1.5 \%$ & $70.9 \pm 1.3 \%$ \\
\hline B1 FGE & $39.0 \pm 0.1 \%$ & $40 \pm 1.8 \%$ & $45 \pm 0.5 \%$ & 0 (No STSs) & 0 (No STSs) \\
\hline B2 FGE & $35 \pm 1 \%$ & $42 \pm 0.4 \%$ & $46 \pm 0.1 \%$ & $36 \pm 2.9 \%$ & $37 \pm 4.4 \%$ \\
\hline B2 FPE (with B2CC) & $\mathrm{N} / \mathrm{A}$ (No B2CC) & $\mathrm{N} / \mathrm{A}$ (No B2CC) & $\mathrm{N} / \mathrm{A}$ (No B2CC) & $61 \pm 2.0 \%$ & $64.63 \pm 3.5 \%$ \\
\hline FPE (B2 + Spillway) & N/A (B2 Priority) & $55 \pm 0.4 \%$ & $84 \pm 0.5 \%$ & $77 \pm 0.02 \%$ & $82 \pm 0.02 \%$ \\
\hline Surface Route Percent of Flow & & & 0.24 & $3.3 \%$ & $3.5 \%$ \\
\hline Surface-Passage Efficiency (all) & $N / A$ & $\mathrm{~N} / \mathrm{A}$ & $10.0 \pm 0.1 \%$ & $25.8 \pm 0.5 \%$ & $26.2 \pm 0.7 \%$ \\
\hline Project-Wide B1 Sluiceway Efficiency & $\mathrm{N} / \mathrm{A}$ & $\mathrm{N} / \mathrm{A}$ & $10.0 \pm 0.1 \%$ & $5.9 \pm 0.1 \%$ & $5.13 \pm 0.2 \%$ \\
\hline B1 Sluiceway Efficiency (\% of B1) & $\mathrm{N} / \mathrm{A}$ & $\mathrm{N} / \mathrm{A}$ & $29.1 \pm 0.7 \%$ & $37.6 \pm 1.5 \%$ & $70.9 \pm 1.2 \%$ \\
\hline Project-Wide B2CC Efficiency & $\mathrm{N} / \mathrm{A}$ & $N / A$ & $N / A$ & $19.9 \pm 0.4 \%$ & $21.1 \pm 0.6 \%$ \\
\hline B2CC Efficiency (Re: B2) & $\mathrm{N} / \mathrm{A}$ & $N / A$ & $\mathrm{~N} / \mathrm{A}$ & $39.6 \pm 1.5 \%$ & $43.5 \pm 2.5 \%$ \\
\hline Spill Effectiveness & $1.21 \pm 0.01$ & $2.25 \pm 0.01$ & $1.12 \pm 0.01$ & $1.02 \pm 0.02$ & $0.86 \pm 0.03$ \\
\hline Surface-Passage Effectiveness (all) & $\mathrm{N} / \mathrm{A}$ & $\mathrm{N} / \mathrm{A}$ & $42.8 \pm 0.03$ & $7.9 \pm 0.15$ & $7.60 \pm 0.22$ \\
\hline $\begin{array}{l}\text { Project-Wide B1 Sluiceway } \\
\text { Effectiveness }\end{array}$ & $\mathrm{N} / \mathrm{A}$ & $\mathrm{N} / \mathrm{A}$ & $42.8 \pm 0.03$ & $10.9 \pm 0.2$ & $8.6 \pm 0.3$ \\
\hline B1 Sluiceway Effectiveness (Re: B1) & $\mathrm{N} / \mathrm{A}$ & $N / A$ & $26.9 \pm 6.6$ & $9.3 \pm 0.4$ & $4.3 \pm 0.08$ \\
\hline Project-Wide B2CC Effectiveness & $\mathrm{N} / \mathrm{A}$ & $\mathrm{N} / \mathrm{A}$ & $\mathrm{N} / \mathrm{A}$ & $7.3 \pm 0.14$ & $7.4 \pm 0.21$ \\
\hline B2CC Effectiveness (Re: B2) & $\mathrm{N} / \mathrm{A}$ & $\mathrm{N} / \mathrm{A}$ & $N / A$ & $7.7 \pm 0.28$ & $6.8 \pm 0.4$ \\
\hline
\end{tabular}


A similar trend of high effectiveness at low flow percentages was observed for the $\mathrm{B} 2 \mathrm{CC}$, where predicted effectiveness was about 8:1 at 4\% of B2 flow through the B2CC and about 4:1 at 15\% flow. The range of percent flow for the B2CC (4\%-15\% of B2 flow) was much narrower than it was for the B1 sluiceway (1\%-100\% of B1 flow) and the spillway (4\%-80\% of project flow), and this probably explains why the fit of a regression curve was worse for the $\mathrm{B} 2 \mathrm{CC}$ data than it was for the $\mathrm{B} 1$ sluiceway data. During normal operation of the $\mathrm{B} 2 \mathrm{CC}$ ( $4 \%$ of $\mathrm{B} 2$ flow), $\mathrm{B} 2 \mathrm{CC}$ effectiveness was about 5.33 times higher than spill effectiveness.

Logit regressions explained $95 \%$ of the variation in percent fish passage for B2 turbines, $75 \%$ for B1 turbines, and just $50 \%$ for the spillway, but trends in fitted curves for these routes were similar. The fit of the spillway regression was degraded by the addition of 2005 data, which tended to have lower spillway efficiency estimates than those recorded in prior years. In three of the five years $(2001,2002$, and 2004), the fit of regression lines was significantly better $\left(\mathrm{r}^{2}=0.76-0.87\right)$ than the fit of a regression line fit to all data $\left(r^{2}=0.50\right)$. In 2005 , the fit $\left(r^{2}=0.47\right)$ of spill passage efficiency on percent spill was comparable to that of the overall regression, but in 2000 the $r^{2}$ was just $31 \%$. Trends in spill efficiency also varied among years with slopes ranging from 0.88 to $1.31($ mean $=1.13)$.

Day and night estimates of percent spill from the five years of study explained 52\% of the variation in fish passage efficiency. Fish passage efficiency, which is the percent of total passage through non-turbine routes, increased from an average of $50 \%$ when there was no spill to about $90 \%$ when percent spill was about $78 \%$ of total project flow. Each $1 \%$ increase in percent spill buys a $0.55 \%$ increase in non-turbine passage. Regression lines varied a lot among years, with percent spill explaining from $47 \%$ to $79 \%$ of the variation in fish-passage efficiency.

Predictions of percent passage through surface flow routes were much higher than predictions for the spillway or turbines at low percent flow (Figure S.1), and compared to adjacent turbines, efficiency data indicate a clear preference of fish for surface routes over turbine routes (e.g., Figure S.2). At 15\% of project flow, the spillway, B1 turbines, and B2 turbines only passed an average of $22 \%, 5 \%$, and $10 \%$ of project fish passage compared with $49 \%$ through surface routes (Figure S.1). On average (Figure S.2), the percent of B1 passage through the B1 sluiceway was about $40 \%$ at $1 \%$ of B1 flow (the minimum sluiceway flow), $73 \%$ at $5 \%$ flow, $83 \%$ at $10 \%$ flow, and $88 \%$ at $15 \%$ flow. The percent of $\mathrm{B} 2$ passage through the $\mathrm{B} 2 \mathrm{CC}$ was $30 \%$ at $4 \%$ of $\mathrm{B} 2$ flow (the minimum flow), $36 \%$ at $5 \%$ flow, $52 \%$ at $10 \%$ flow, and $62 \%$ at $15 \%$ flow (Figure S.3). 


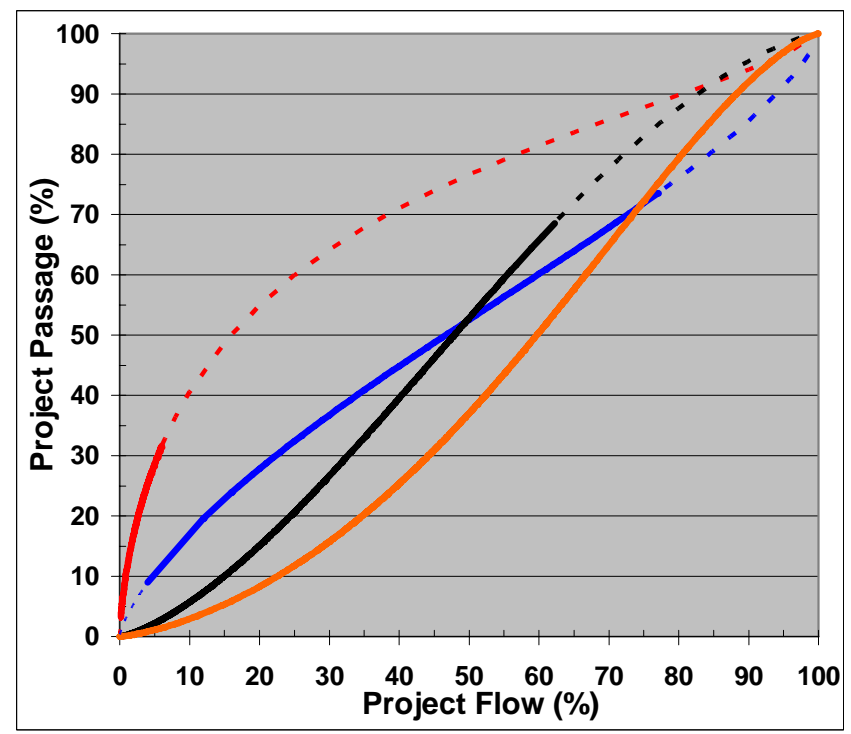

Figure S.1. Logit Regressions Lines Summarizing Percent of Project Passage by Route as a Function of Percent of Project Flow through the Same Route. The red line is the predicted response for surface flow outlets, blue is for spill, black for B1 turbines, and gold for B2 turbines. Lightly dashed portions of lines are extrapolations to known endpoints.

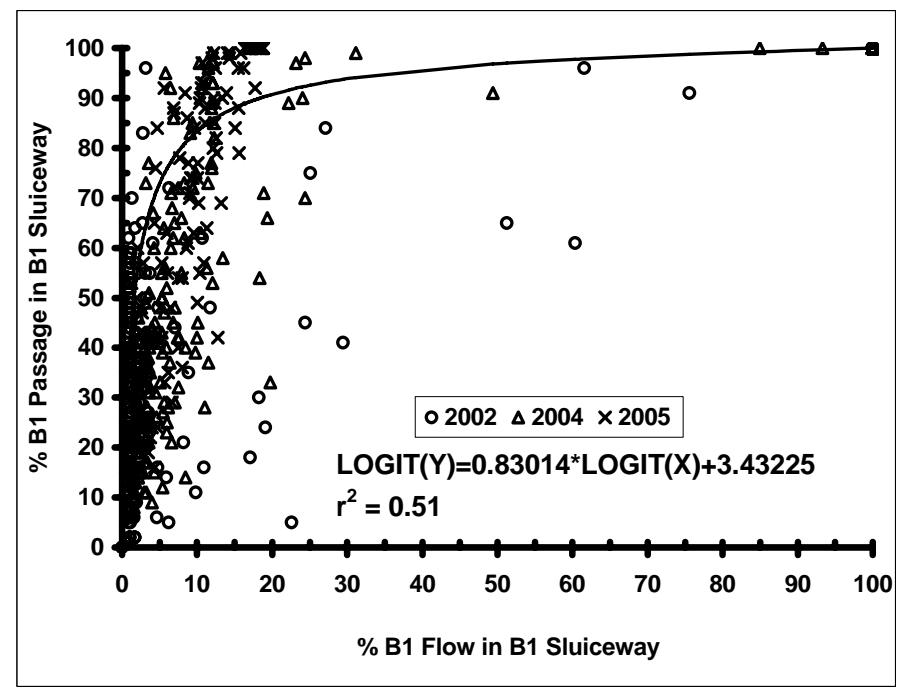

Figure S.2. Logit Regression of Day and Night Estimates of B1 Sluiceway Passage Efficiency on Percent of B1 Flow Passing the B1 Sluiceway 


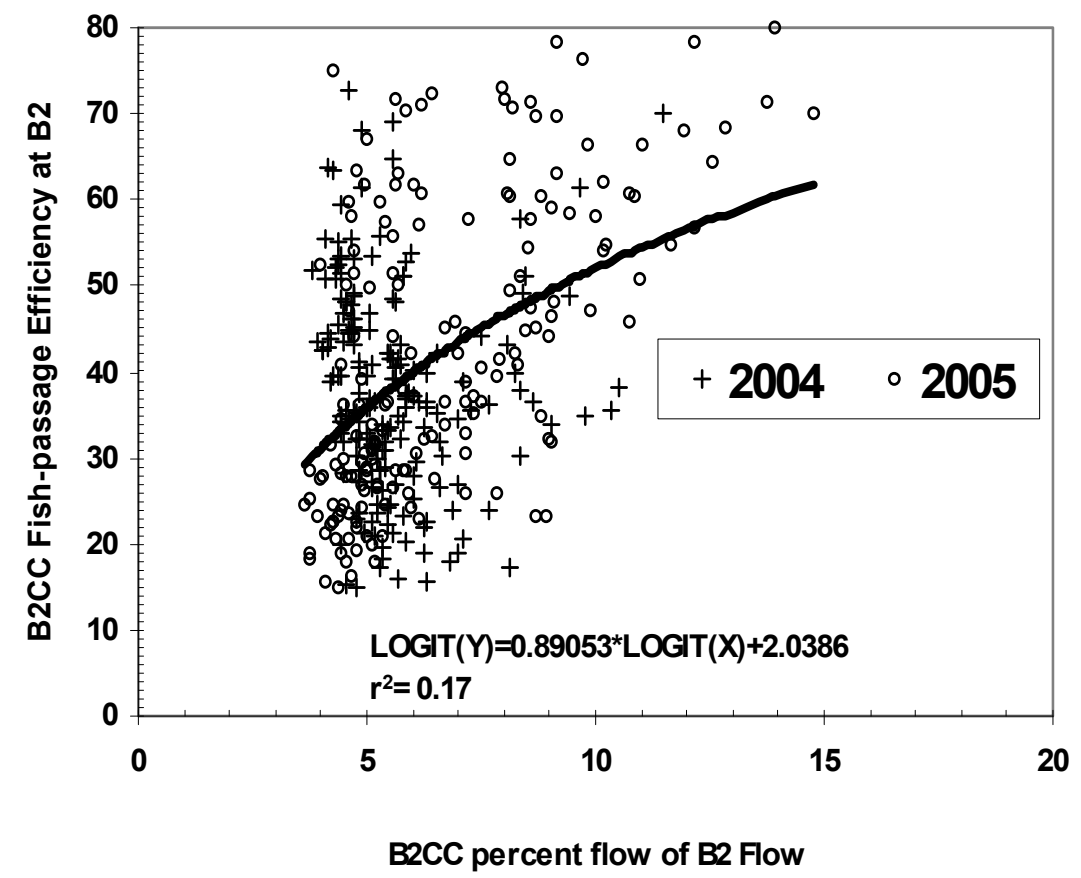

Figure S.3. Logit Regression of Day and Night Estimates of the B2CC Passage Efficiency on Percent of B2 Flow Passing into the B2CC with No Extrapolation

Spill has been used to increase non-turbine passage at Bonneville Dam, but it is not an efficient use of water because the project has two islands that isolate spillway flow from powerhouse flow before fish can select a preferred route. Consequently, spill efficiency will always be directly proportional to percent spill, with effectiveness ranging from about 0.7 to 1.3 . We recommend a more efficient approach to increase non-turbine passage, i.e., optimizing percent flow to the B1-sluiceway and B2CC because these routes can reduce turbine passage by out competing adjacent turbines for fish. The spillway cannot compete directly with turbines for fish because of the islands. We are not saying that spill should be eliminated, but it may be possible to reduce reliance on spill to pass juvenile salmonids by fully realizing all potential benefits of surface passage through structural and operational changes.

Turbines are about as efficient as the spillway at any percent of project flow, but surface routes are much more efficient than turbines at low percent flow. The average percent of B1 flow through the B1 sluiceway (1\%-2\%) is well below an optimum amount of $10 \%$, but hopefully planned improvements in that system will greatly improve its performance in the future. Given the very high effectiveness of surface routes at the lowest flow, we recommend testing the use of many low-flow surface outlets at B1 versus the use of a few outlets passing equivalent flow. Without structural modification, attaining $10 \% \mathrm{~B} 1$ flow to the sluiceway requires shutting down turbines, which is how $50 \%-100 \%$ of B1 flow to the sluiceway was possible at times (Figure S2). Given the B2 powerhouse priority, it is difficult to imagine increasing percent of B2 flow to the B2CC much above the median 4\% observed in 2004 and 2005. The installation and testing of a smolt guidance device in the $\mathrm{B} 2$ forebay may be a viable alternative to increasing percent flow from $4 \%$ to $15 \%$. Previous observations of $10 \%-15 \%$ of $\mathrm{B} 2$ flow to the $\mathrm{B} 2 \mathrm{CC}$ always occurred at night when turbines were shut down to accommodate increased spill (to the gas cap) at night. Of course, a thorough understanding of route-specific survival is critical for choosing the best route for fish. 


\section{Preface}

This report was prepared by the Pacific Northwest National Laboratory (PNNL), Richland, Washington, with support from the Pacific States Marine Fisheries Commission. The Portland District of the U.S. Army Corps of Engineers provided funding and oversight.

\section{Acknowledgments}

Many people made valuable contributions to this study and deserve acknowledgment. First and foremost, authors of all five original technical reports deserve credit for preparing those materials, and this re-analysis takes nothing away from the high quality of those studies. Second, all of the people acknowledged in those reports deserve credit because the data that went into the original reports and this re-analysis would not exist if not for their hard work. This includes many of the wonderful technicians that routed cables, kept equipment operational, and downloaded data, as well as logistical, crane, and rigger support from the Bonneville Dam Project. Finally, we thank the Portland District of the U.S. Army Corps of Engineers for the foresight to support this long-term effort that allowed an examination of among-year variation while studying things of immediate concern in a given year. Blaine Ebberts was the Contracting Officer's Representative for the 2000, 2001, 2002, and part of the 2004 studies, and Dennis Schwartz took over for 2004 and 2005.

Subcontractors that provided invaluable support for these studies are acknowledged in each year's technical report. 
Re-Analysis of Hydroacoustic Fish-Passage Data from Bonneville Dam after Spill-Discharge Corrections 


\section{Acronyms and Abbreviations}

$\begin{array}{ll}\text { B1 } & \text { Bonneville Powerhouse 1 } \\ \text { B2 } & \text { Bonneville Powerhouse 2 } \\ \text { B2CC } & \text { Bonneville Powerhouse 2 Corner Collector } \\ \text { BPA } & \text { Bonneville Power Administration } \\ \text { cfs } & \text { cubic feet per second } \\ \text { EBA } & \text { effective beam angle } \\ \text { FGE } & \text { fish guidance efficiency at a turbine or intake [Guided / (Guided + Unguided)] } \\ \text { FPE } & \text { fish passage efficiency [Guided / (Guided + Unguided) by Project or Powerhouse] } \\ \text { MSL } & \text { mean sea level } \\ \text { PDF } & \text { portable document file } \\ \text { PNNL } & \text { Pacific Northwest National Laboratory } \\ \text { PSC } & \text { Prototype Surface Collector } \\ \text { S } & \text { second } \\ \text { SAS } & \text { Statistical Analysis System } \\ \text { TDG } & \text { total dissolved gas } \\ \text { TIE } & \text { turbine intake extension }\end{array}$


Re-Analysis of Hydroacoustic Fish-Passage Data from Bonneville Dam after Spill-Discharge Corrections 


\section{Contents}

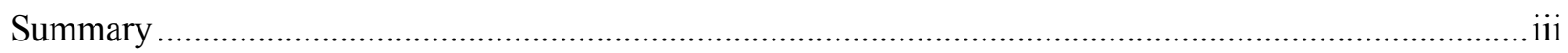

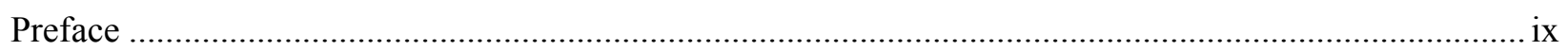

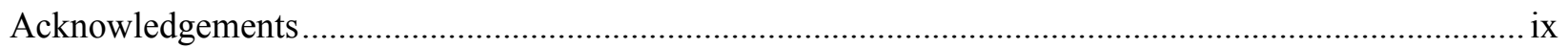

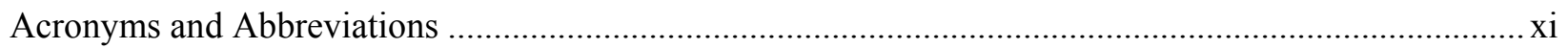

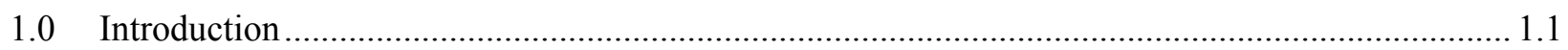

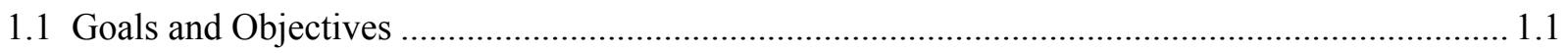

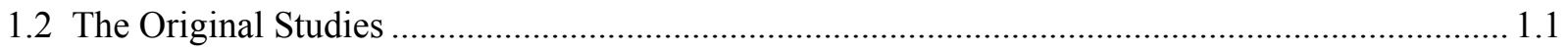

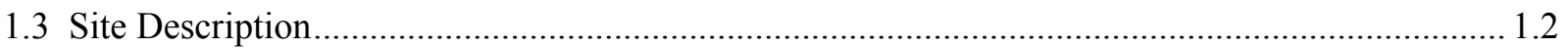

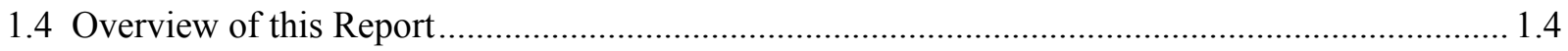

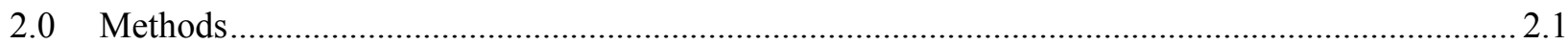

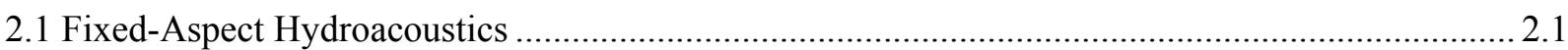

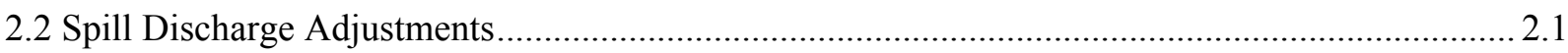

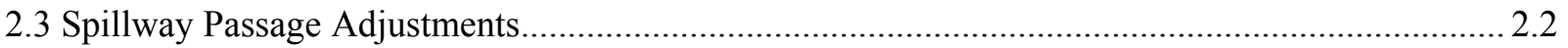

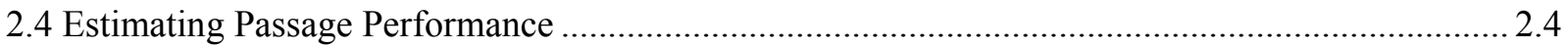

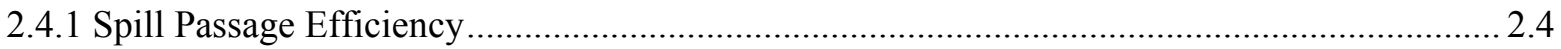

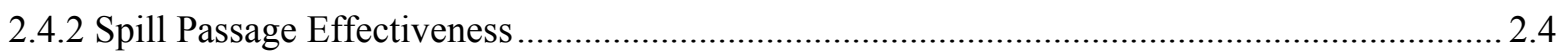

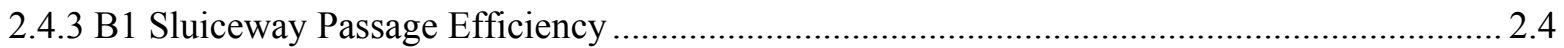

2.4.4 B1 Sluiceway Passage Effectiveness …................................................................................... 2.5

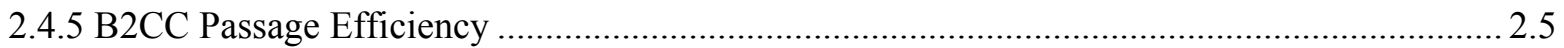

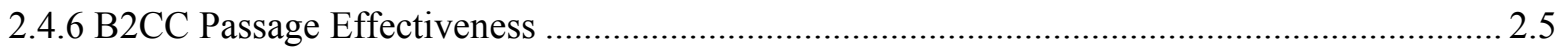

2.4.7 Project Fish-Passage Efficiency (FPE) ............................................................................. 2.6

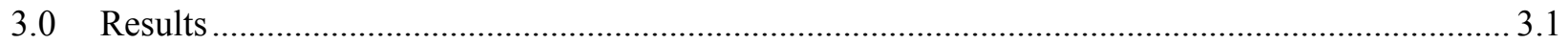

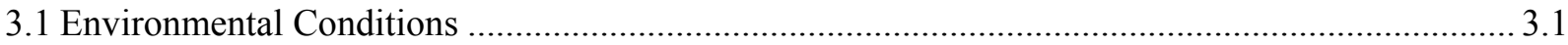

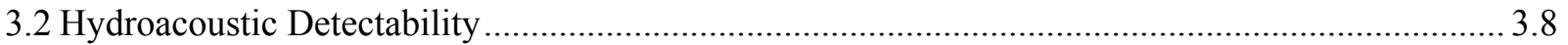

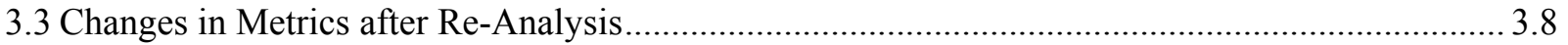

3.4 Relations Between Passage Metrics and Percent Flow by Route ............................................... 3.15 


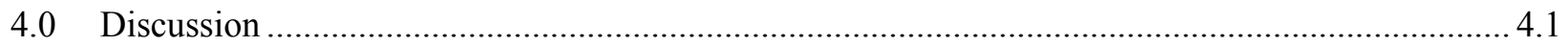

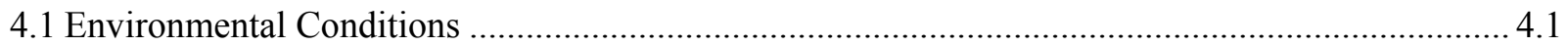

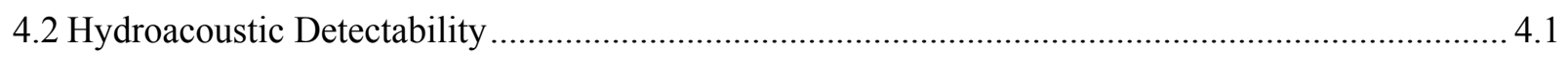

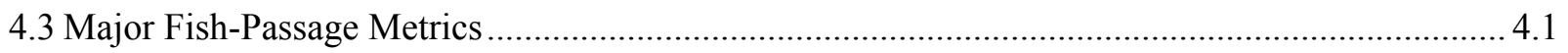

4.4 Relations between Passage Metrics and Percent Flow by Route ............................................... 4.2

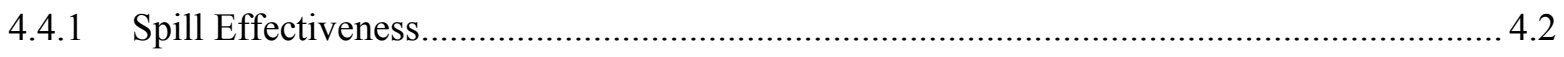

4.4.2 Surface Passage Effectiveness ................................................................................... 4.2

4.4.3 Relative Efficiency as a Function of Percent Flow …....................................................... 4.3

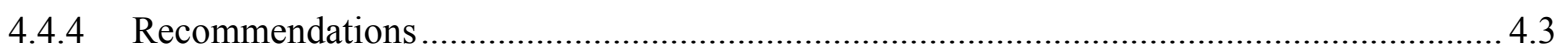

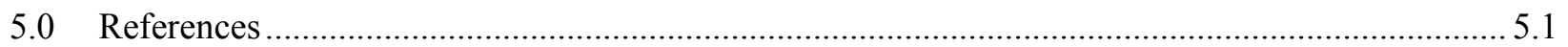




\section{Figures}

Figure 1.1. Plan View of the Bonneville Dam Project. 1.3

Figure 1.2. Columbia River Discharge (\% and CFS) from 1996 through 2005 during Spring and Summer Sampling with Fixed-Aspect Hydroacoustic Methods. 1.4

Figure 2.1. Plots of Reported and Actual Spill Discharge for 2000, 2001, 2002, and 2004. 2.1

Figure 2.2. Plot of Effective Beam Angle as a Function of Range and Spill Bay Discharge in Summer 2005

Figure 2.3. Plots of a Fish-Passage Scalar as a Function of Spill Bay Discharge.

Figure 3.1. Historical Among-Year Trends in Percent Spill (Top) and Project and Spill Discharge (Bottom) at Bonneville Dam through 2005

Figure 3.2. Day and Night Estimates of Percent Spill (Top), Total Project Discharge, and Spill Discharge during the Five Study Periods

Figure 3.3. Smolt Monitoring Program (SMP) Passage Index for April 15 - July 15, 1996 _................. 3.3

Figure 3.4. Smolt Monitoring Program (SMP) Passage Index for April 15 - July 15, 2000 ................... 3.4

Figure 3.5. Smolt Monitoring Program (SMP) Passage Index for April 15 - July 15, 2001 ................... 3.4

Figure 3.6. Smolt Monitoring Program (SMP) Passage Index for April 15 - July 15, 2002 .................. 3.5

Figure 3.7. Smolt Monitoring Program (SMP) Passage Index for April 15 - July 15, 2004 .................. 3.5

Figure 3.8. Smolt Monitoring Program (SMP) Passage Index for April 15 - July 15, 2005 .................. 3.6

Figure 3.9. Spill Discharge Rate by Date in Summer 2004 ................................................................ 3.6

Figure 3.10. Spill Discharge Rate by Date in Spring 2005 ........................................................... 3.7

Figure 3.11. Mean Hourly Spill and Turbine Discharge in Spring and Summer 2005 ......................... 3.7

Figure 3.12. Regression of Fish-Passage Efficiency and Spill-Passage Efficiency on Percent Spill Using Corrected and Uncorrected Data Estimates for 2000, 2001, 2002, and 2004. 3.8

Figure 3.13. Bar Chart Showing Original and Revised Estimates in Spring Spill Effectiveness from 2000 through 2004.

Figure 3.14. Bar Chart Showing Original and Revised Estimates in Summer Spill Effectiveness from 2000 through 2004

Figure 3.15. Bar Chart Showing the Decrease in Surface-Passage Effectiveness that Resulted from Adjusting Spill Discharge in 2002 and 2004

Figure 3.16. Regression of Day and Night Estimates of Spill-Passage Effectiveness on Percent Spill

Figure 3.17. Regression of Day and Night Estimates of Spill-Passage Effectiveness on Percent Spill by Year...

Figure 3.18. Regression of Day and Night Estimates of B1 Sluiceway Effectiveness on Percent of B1 Flow and Spill-Passage Effectiveness on Percent of Project Flow Spilled ................... 3.16

Figure 3.19. Regression of Day and Night Estimates of B2CC Effectiveness on Percent of B2 Flow and Spill-Passage Effectiveness on Percent of Project Flow Spilled 
Figure 3.20. Logit Regression of Day and Night Estimates of B2 Turbine Passage Efficiency on Percent of Project Flow through B2 Turbines

Figure 3.21. Logit Regression of Day and Night Estimates of B1 Turbine Passage Efficiency on Percent of Project Flow through B1 Turbines

Figure 3.22. Regression of Day and Night Estimates of Spillway Efficiency on Percent Spill

Figure 3.23. Logit Regression of Day and Night Estimates of Spill Passage Efficiency on Percent Spill including 112 0,0 Points Observed in 2001

Figure 3.24. Logit Regression of Day and Night Estimates of B1 Sluiceway Passage Efficiency on Percent of B1 Flow Passing the B1 Sluiceway.

Figure 3.25. Logit Regression of Day and Night Estimates of the B2CC Passage Efficiency on Percent of B2 Flow Passing into the B2CC with Full Extrapolation to Known Endpoints Shown as a Dashed Line

Figure 3.26. Logit Regression of Day and Night Estimates of the B2CC Passage Efficiency on Percent of B2 Flow Passing into the B2CC with No Extrapolation

Figure 3.27. Logit Regression of Day and Night Estimates of Percent of Project Fish Passage through Surface Flow Outlets on Percent of Project Flow through the Same Routes

Figure 3.28. Logit Regression Lines Summarizing Percent of Project Passage by Route as a Function of Percent of Project Flow through the Same Route

Figure 3.29. Regression of Fish-Passage Efficiency on Percent Spill for Bonneville Dam

Figure 3.30. Regression of Fish-Passage Efficiency on Percent Spill by Year of Study at Bonneville Dam.

Figure 3.31. Regression of Spill Efficiency on Percent Spill by Year of Study at Bonneville Dam 


\section{Tables}

Table 3.1. Differences in Spring Flow and Fish-Passage Metrics Calculated by Subtracting Previously Reported Estimates from Revised Estimates in this Report ................................ 3.9

Table 3.2. Differences in Summer Flow and Fish-Passage Metrics Calculated by Subtracting Previously Reported Estimates from Revised Estimates in this Report

Table 3.3. Estimates of Major Flow and Passage Metrics $\pm 1 / 295 \%$ Confidence Limits for Spring Based upon Hydroacoustic Sampling in 2000, 2001, 2002, 2004, and 2005

Table 3.4. Estimates of Major Flow and Passage Metrics $\pm 1 / 295 \%$ Confidence Limits for Summer Based upon Hydroacoustic Sampling in 2000, 2001, 2002, 2004, and 2005

Table 4.1. Radio Telemetry Estimates of Spill Effectiveness at Bonneville Dam during Study Years 
Re-Analysis of Hydroacoustic Fish-Passage Data from Bonneville Dam after Spill-Discharge Corrections 


\subsection{Introduction}

The Portland District of the U.S. Army Corps of Engineers requested that the Pacific Northwest National Laboratory (PNNL) re-analyze four years of fixed-aspect hydroacoustic data after the District made adjustments to spill discharge estimates that may have been sufficient to alter previous results and conclusions. Results of the 2005 study also are presented in this report. This study supports the Portland District and its effort to maximize survival of juvenile salmon passing Bonneville Dam.

\subsection{Goals and Objectives}

The goal of this study was to re-analyze four years of spill and fish-passage data using accurate estimates of spill discharge, Project discharge, and percent spill. Objectives were as follows:

1. Make adjustments to hourly spill discharge estimates for the years 2000 and 2001 based upon reported and actual estimates provided by the Portland District and use revised spill discharge estimates for 2002 and 2004 provided to us by the Hydraulics Branch, Portland District. These are years in which fixed-aspect hydroacoustic samples were collected from major passage routes but spill discharge data were not accurate, particularly at low spill discharge levels.

2. Examine relations between fish-passage metrics and spill variables including discharge and percent spill to identify and describe underlying patterns in the data for all years, including 2005. Revisit findings in earlier reports and revise them as necessary.

3. Write a report describing revised fish passage metrics in each of the four years of reporting and summarize effects of flow for all five years of study.

\subsection{The Original Studies}

The Portland District funded five full-project, fixed-aspect hydroacoustic studies of fish-passage efficiency at Bonneville Dam. The first study was conducted in 2000 by the Engineer Research and Development Center, U.S. Army Corps of Engineers, Vicksburg, Mississippi (Ploskey et al. 2002a). Subsequent studies in 2001 (Ploskey et al. 2002b), 2002 (Ploskey et al. 2003), 2004 (Ploskey et al. 2005), and 2005 (Ploskey et al. 2006) were conducted by PNNL, Richland, Washington.

Each year of study had unique characteristics. In 2000, the Prototype Surface Collector (PSC) at B1 units 1-6 was tested and B1 was given priority for generation to support that study. In contrast, B1 had a lower priority for generation than B2 in all subsequent years. The 2001 study occurred during a drought year in which spill was limited in duration and amount each season. While the drought provided unique opportunities to examine the effect of very low spill and no spill, it also made difficult comparisons of metrics between 2001 and other years. Studies in 2002 and 2004 were conducted under closer-to-average water conditions and with comparable methods, but 2004 had an operational B2CC and 2002 did not. There was no hydroacoustics study at Bonneville Dam in 2003. Hydroacoustic sampling for shallow B1 sluiceway entrances were not developed until 2002, so some of the differences in passage metrics before and after 2002 result from changes in sampling methods.

Of the five years of project-wide sampling, results for 2004 and 2005 should be the most comparable because of the consistency of sampling methods, river discharge, and dam operations in those years. During hydroacoustic sampling in 2004 and 2005, no submerged traveling screens were installed at B1; three B1 sluiceway outlets from the forebay were opened; B2 was the priority powerhouse for generation; no turbine intake extensions (TIES) were installed upstream of B2 turbines 11 through 14; and the B2CC 
was passing water and fish. The 2005 configuration of passage routes and operations was similar to that evaluated in 2004, but river discharge was $10 \%$ lower in 2005 . It was $75 \%$ of the 10 -year average from 1996 to 2005 . It was $85 \%$ of the 10 -year average in 2004 . In study years before 2004, TIES were installed in every other B2 intake from 11A through 18B. Removal of TIES from intakes at units 11-14 in 2004 and 2005 facilitated southerly flow along the powerhouse toward the B2CC. Two of the three B1 sluiceway outlets sampled in 2005 were located about $60 \mathrm{ft}$ to the south of the outlets sampled in 2004. Outlets 2C, 4C, and 6C were opened and were sampled in 2004, and Outlets 1C, 3C, and 6C were opened and sampled in 2005.

Besides the B2CC, the 2004 and 2005 passage years were unique in that no in-turbine screens were deployed in the 30 B1 turbine intakes, where there are three intakes per turbine. Before 2004, submerged traveling screens (STS) were deployed in most B1 intakes. The exception was that extended length submersible bar screens were installed in all intakes of Unit 8 and tested in 2001 and 2002. Regional fish managers decided not to have screens deployed at B1 in 2004 and 2005, after they examined survival estimates for fish passing B1 turbines and noted that survival was higher for fish passing through minimum gap runner (MGR) turbines than it was for fish passing through the juvenile bypass system. Experimentally modified gatewell slots of some B2 turbines were operational in 2002 (Unit 15) and 2004 and 2005 (Units 15 and 17) but not in previous years. These modifications were designed to increase flow up submerged traveling screens and into gatewell slots to improve screen guidance efficiency.

\subsection{Site Description}

Bonneville Dam consists of several dam structures that together impound the Columbia River between Oregon and Washington at River Mile 146.1, about 40 miles east of Portland, Oregon. From the Oregon shore north toward Washington, the Project currently is composed of a navigation lock, a 10turbine-unit Powerhouse 1 (B1), Bradford Island, an 18-gate spillway, Cascades Island, and an 8-turbineunit Powerhouse 2 (B2), as shown in Figure 1.1. The turbine units are numbered from 1 to 10 south to north at B1 and from 11 to 18 south to north at B2. Each unit has three intakes: A, B, and C. The B1 sluiceway has chain gates above every turbine intake, but usually only three of the 30 outlets are opened to allow flow into the B1 sluiceway channel.

Bonneville Dam was formally authorized by Congress in the Rivers and Harbor Act of August 30, 1935. This act also provided the authority for the construction of additional hydroelectric generation facilities when requested by the Administrator of the Bonneville Power Administration (BPA). The spillway and B1 were constructed between 1933 and 1937 without specific regard for protecting juvenile salmonids migrating downstream. Public Law 329, passed by the 75th Congress on August 20, 1937, provided authority for the completion, maintenance, and operations of Bonneville Dam. Administrative letters of BPA in 1965 stated the need for the construction of B2. Construction of turbine units 11 through 18 and two fish units at B2 began in 1974 and ended in 1982.

Principal passage routes for juvenile salmonids include the spillway and two powerhouses, but within each powerhouse, fish passage can be through ice and trash sluiceways, turbines, or the juvenile bypass system (JBS). Smolts enter the JBS after they encounter screens in the upper part of turbine intakes and are diverted to gatewell slots and orifices opening to a bypass channel. In spring 2004, the B2 Corner Collector (B2CC) became fully operational (Figure 1.1). It was converted from the old B2 Sluice Chute in the fall and winter of 2003-2004. The B2CC outlet provides a passage route for high concentrations of smolts at the south end of B2 on the north side of Cascades Island. The B2CC channel 
transports fish from the B2 forebay to the downstream tip of Cascades Island between the spillway and B2 tailwaters.

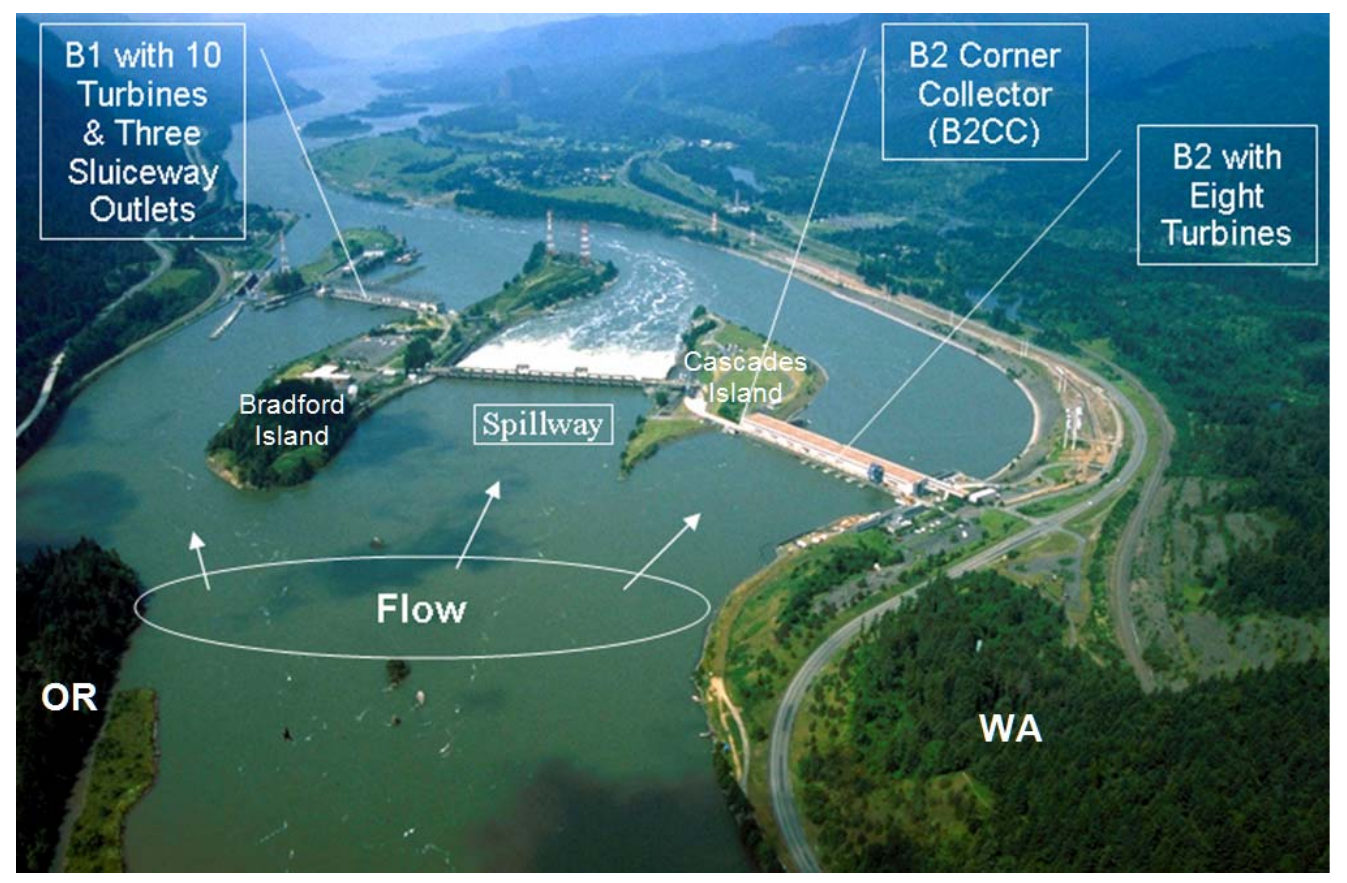

Figure 1.1. Plan View of the Bonneville Dam Project. The B1 sluiceway outlets and B2CC are surface (overflow) routes.

Project fish passage efficiency (FPE) is the estimated proportion of all juvenile salmon passing the Project by non-turbine routes, but FPE also can be calculated for individual powerhouses (B1 and B2) or for either powerhouse plus the spillway. In all cases, FPE is estimated non-turbine passage divided by the total passage at the Project for a passage season. Non-turbine passage consists of the sum of passage through B1 sluiceway outlets, the B1 JBS, the spillway, the B2CC, and the B2 JBS. The B1 JBS was not operated in 2004 and 2005.

In a typical water year, the goal of maximizing FPE largely determines the operation of the Project. Managers presume that large volumes of spill are necessary to compensate for the low fish guidance efficiency (FGE) of in-turbine screens, particularly in summer. In a typical year, spill volumes are limited to between 50,000 and 75,000 cfs during the day and up to $120 \%$ of the "gas cap" at night. The gas cap was established to control total dissolved gas supersaturation, which is harmful to fish (NOAA Fisheries 2000).

Within general guidelines, however, there is a great deal of variability among passage years. The two most obvious determinants of dam operations are water availability in the reservoir and the demand for hydropower generation. The drought of 2001 was an extreme case wherein discharge was only $48 \%$ of the ten-year average annual discharge from 1996-2005 (Figure 1.2), which, combined with very high generation demand, led to unusually low spill volumes over a curtailed spill season (Ploskey et al. 2002b). In 2001, the project spilled $16 \%$ of the total discharge in spring and $11 \%$ in summer, down from $31 \%$ and $50 \%$, respectively, in 2000. Total spill volume was less than a quarter (23\%) in spring and less than an eighth (12\%) in summer of what it was in 2000, a much more normal water and generation year. 


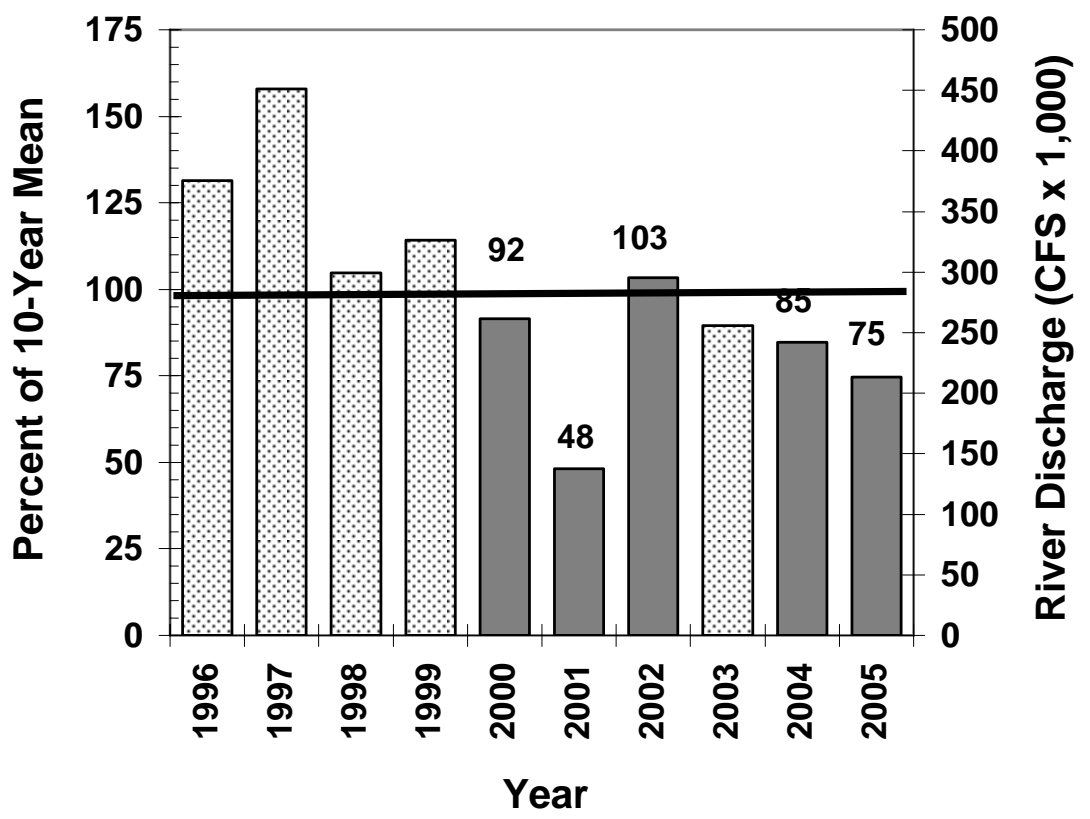

Figure 1.2. Columbia River Discharge (\% and CFS) from 1996 through 2005 during Spring and Summer Sampling with Fixed-Aspect Hydroacoustic Methods. Data are from the Dart Website (http://www.cbr.washington.edu/dart/). Gray bars with percent labels highlight years with enough sampling data to estimate fish-passage efficiency for the Project. The heavy black line at 100 percent indicates the 10-year-average.

Even without the complications of unusual water years and generation demand, conducting dam operations to enhance fish passage and survival is a complex affair. Spill under 50,000 cfs creates eddies and slack water areas in the spillway tailrace. High risk of predation is assumed in the tailrace when currents do not carry juvenile fish downstream quickly. Spill levels $>75,000 \mathrm{cfs}$ during the day can lead to high numbers of adult salmon falling back through the spillway, as adults exit the Bradford Island fish ladder and follow the shoreline around to the spillway forebay. Adult salmon do not pass through the ladder at night, and therefore spill can be increased in an attempt to maximize FPE for a 24-hour period. However, spill >120,000 cfs typically causes total dissolved gas (TDG) levels to exceed $120 \%$ of saturation, which is the allowable maximum set by state water-quality standard waivers. Levels of TDG above this may increase fish mortality downstream of the dam.

\subsection{Overview of this Report}

After this introduction (Chapter 1), there are chapters presenting methods (2), results (3), discussion (4), and literature cited (5). 


\subsection{Methods}

\subsection{Fixed-Aspect Hydroacoustics}

Fixed-aspect hydroacoustic methods were described in detail in technical reports for 2000 (Ploskey et al. 2002a), 2001 (Ploskey et al. 2002b); 2002 (Ploskey et al. 2003); 2004 (Ploskey et al. 2005); and 2005 (Ploskey et al. 2006). Changes since those reports resulted from our adjustments to spill-discharge estimates for 2000 and 2001, the use of 2002 and 2004 spill-discharge estimates provided by the Portland District, and our adjustments to counts of spillway-passed fish in years before 2005, as described below.

\subsection{Spill Discharge Adjustments}

Actual spill discharge estimates were less than what was reported in Bonneville Dam operations data in 2000 and 2001 (by 7.5-12.4\%) and in 2002 and 2004 (by 12.7\% to 53.7\%), a fact reported in late 2004 by Laurie Ebner with the Portland District Hydraulics Branch. The percentage error in spill discharge estimates was higher for low spill rates than it was for high rates (Figure 2.1). At the extreme, for example, 50,000 cfs spill reported in 2002 and 2004 was actually only 23,100 cfs.

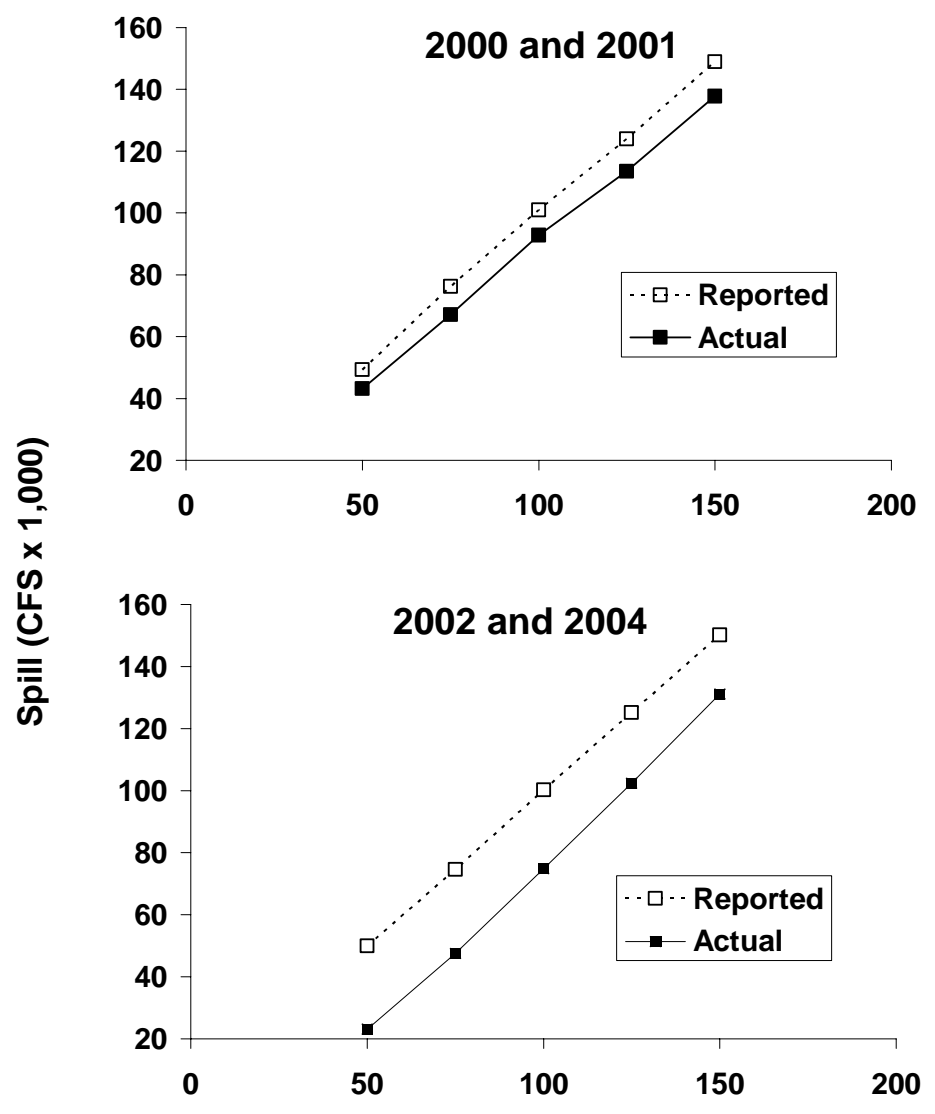

Requested Spill (CFS x 1,000)

Figure 2.1. Plots of Reported and Actual Spill Discharge for 2000 and 2001 (top) and 2002 and 2004 (bottom) 
For 2000 and 2001, we fit a regression equation to District-furnished estimates of reported and actual spill discharge:

$$
2000 \text { and 2001: } y=0.00046 x^{2}+0.858573 x\left(r^{2}=0.99\right)
$$

where $x=$ reported spill and $y=$ actual spill, and we used this equation to calculate actual spill discharge rates for day and night periods. We then estimated bay-specific discharge rates by apportioning spill among bays according to the spill pattern in effect for each year, as described in the Fish Passage Plan for those years (Reservoir Control Center 2000, 2001).

For 2002 and 2004, the Portland District provided revised estimates of spill-bay-specific discharge.

\subsection{Spillway Passage Adjustments}

In 2005, we modeled the detectability of spillway hydroacoustic beams for detecting fish as a function of discharge from 2,000 or 3,000 cfs to 11,000 cfs through individual bays, and we found that effective beam angle decreased as discharge increased (e.g., Figure 2.2). Detectability is expressed as effective beam angle, and it declines as spill-bay discharge increases.

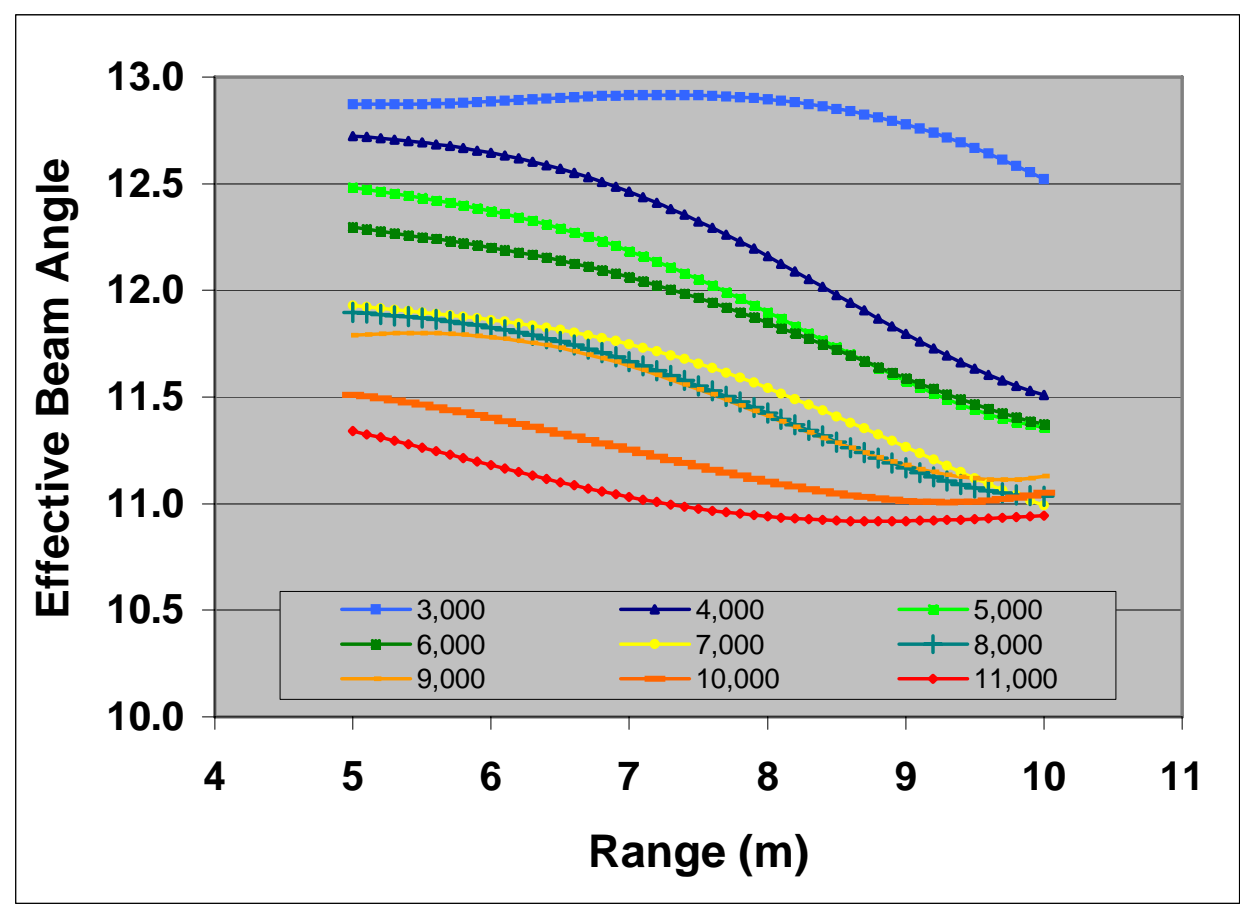

Figure 2.2. Plot of Effective Beam Angle as a Function of Range and Spill Bay Discharge in Summer 2005 (cfs)

The count of each fish detected in a spillway hydroacoustic beam was spatially expanded based upon the ratio of the spill bay width to beam diameter at the range a fish was detected using the following equation: 


$$
E X P_{-} N U M=\frac{O W}{\left[M I D_{-} R \times \operatorname{TAN}\left(\frac{E B A}{2}\right) \times 2\right]}
$$

where OW is opening width (or depth), MID_R is the mid-point range of a trace in m, TAN is the tangent, and EBA is the effective beam angle in degrees.

Spill-bay discharge in 2005 had too big an effect on spatial expansions and resulting fish-passage estimates to be ignored, so we adjusted passage estimates for individual spill bays in 2000, 2001, 2002, and 2004, by multiplying hourly estimates by an hourly and discharge-specific scalar (Figure 2.3).

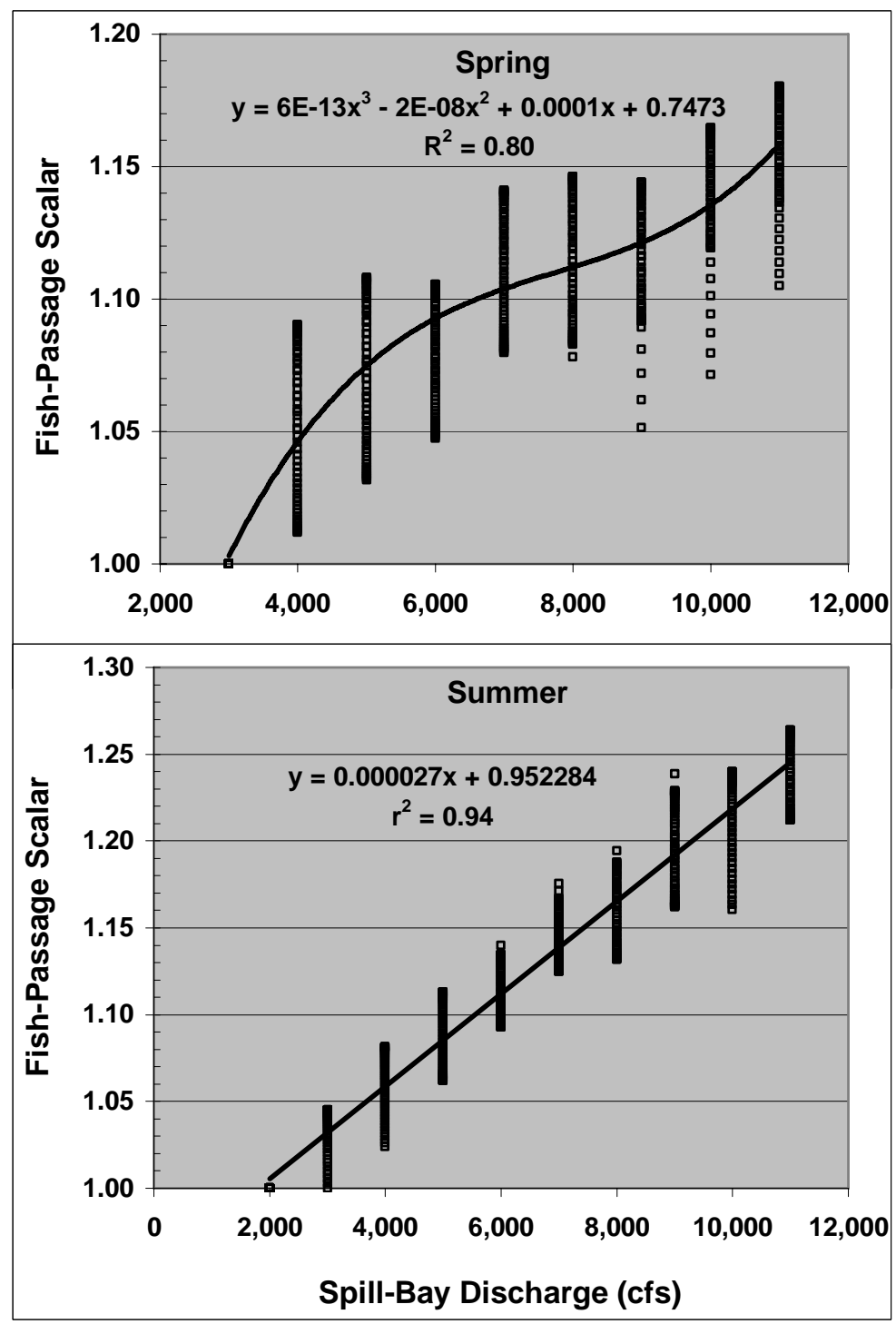

Figure 2.3. Plots of a Fish-Passage Scalar as a Function of Spill Bay Discharge. Variation in the scalar at specific discharge levels resulted from variation in the range of detection in 2005 data. 


\subsection{Estimating Passage Performance}

Estimates of fish passage metrics varied among years depending upon available and sampled routes of passage through the project. This section presents calculations of estimators that were used as dependent variables in regression on route-specific flow percentages. Other major metrics listed in Chapter 3 are as defined in the original technical reports.

\subsubsection{Spill Passage Efficiency}

The spill passage efficiency is the proportion of all fish passing the project that pass through the spillway:

$$
\widehat{S P E}=\frac{\hat{S}}{[\hat{S}+\widehat{N S}]},
$$

where the numerator is estimated spillway passage and the denominator is total project passage composed of spill and non-spill fractions.

\subsubsection{Spill Passage Effectiveness}

The spill passage effectiveness at the Bonneville project is estimated as the ratio of spill efficiency to percent spill:

$$
\widehat{S P S}=\frac{\widehat{S P E}}{\frac{V_{S}}{V_{T}}}=\widehat{S P E} \cdot \frac{V_{T}}{V_{S}},
$$

where

$$
\begin{aligned}
& \widehat{S P E}=\text { spill passage efficiency (Equation 2), } \\
& V_{S}=\text { volume of water spilled during the period of inference (day or night), } \\
& V_{T}=\text { total volume of water passing the project during the same period of inference. }
\end{aligned}
$$

\subsubsection{B1 Sluiceway Passage Efficiency}

The B1 Sluiceway passage efficiency is the proportion of all fish passing B1 that pass through the sluiceway:

$$
\widehat{B 1 S L E}=\frac{\widehat{B 1 S L}}{[\widehat{B 1 S L}+\widehat{B 1 T}]},
$$


where $\widehat{B 1 S L}$ is the estimated $\mathrm{B} 1$ sluiceway passage and $\widehat{B 1 T}$ is estimated $\mathrm{B} 1$ turbine passage.

\subsubsection{B1 Sluiceway Passage Effectiveness}

The B1 sluiceway passage effectiveness is the ratio of B1 sluiceway passage efficiency to percent of B1 flow passing the B1 sluiceway:

$$
\widehat{B 1 S L S}=\frac{\widehat{B 1 S L E}}{\frac{V_{B 1 S L}}{V_{B 1}}}=\widehat{B 1 S L E} \cdot \frac{V_{B 1}}{V_{B 1 S L}},
$$

where

$$
\begin{aligned}
& \widehat{B 1 S L E}=\text { B1 sluiceway passage efficiency (Equation 3), } \\
& V_{B 1 S L}=\text { volume of water passing the B1 sluiceway during the period of inference (day or night), } \\
& V_{B 1}=\text { total volume of water passing B1 during the same period of inference. }
\end{aligned}
$$

\subsubsection{B2CC Passage Efficiency}

The B2CC passage efficiency is the proportion of all fish passing B2 that pass through the B2CC:

$$
\widehat{B 2 C C E}=\frac{\widehat{B 2 C C}}{[\widehat{B 2 C C}+\widehat{B 2 T}]},
$$

where $\widehat{B 2 C C}$ is the estimated B2CC passage and $\widehat{B 2 T}$ is estimated B2-turbine passage.

\subsubsection{B2CC Passage Effectiveness}

The passage effectiveness of the B2CC is the ratio of B2CC sluiceway passage efficiency to the percent of B2 flow passing the B2CC:

$$
\widehat{B 2 C C S}=\frac{\widehat{B 2 C C E}}{\frac{V_{B 2 C C}}{V_{B 2}}}=\widehat{B 2 C C E} \cdot \frac{V_{B 2}}{V_{B 2 C C}},
$$

where

$$
\begin{aligned}
& \widehat{B 2 C C E}=\text { B2CC passage efficiency (Equation 5), } \\
& V_{B 2 C C}=\text { volume of water passing the B2CC during the period of inference (day or night), } \\
& V_{B 2}=\text { total volume of water passing B2 during the same period of inference. }
\end{aligned}
$$




\subsubsection{Project Fish Passage Efficiency (FPE)}

The project fish passage efficiency is the proportion of all fish passing the project that pass through nonturbine routes:

$$
\widehat{F P E}=\frac{\hat{G}}{(\hat{G}+\hat{U})},
$$

where $\hat{G}$ is the estimated passage through the B1 sluiceway, B1 JBS, spillway, B2CC, and B2 JBS. Fish that passed through the B1 JBS and B2 JBS were guided by intake screens deployed at B1 in 20002002 and at B2 in all years. The B1 sluiceway was only sampled in 2002, 2004, and 2005. The B2CC was functional and was sampled in 2004 and 2005. 


\subsection{Results}

\subsection{Environmental Conditions}

This section contains a description of hydraulic conditions and juvenile salmonid species compositions during the five years of data acquisition. Available historical data show a trend of gradual decline in Project discharge, spill discharge, and percent spill, even though among-year variability was high (Figure 3.1). The five years of data re-analyzed in this report came from the later years (2000-2002, 2004, and 2005). Of the five years of hydroacoustic study, 2004 was most like the predicted average percent spill and spill discharge per year; 2001 had the lowest discharge and percent spill, and 2002 had the highest. The drought of 2001 produced the lowest annual discharge on record and among the five lowest recorded estimates of spill discharge and percent spill (Figure 3.1).

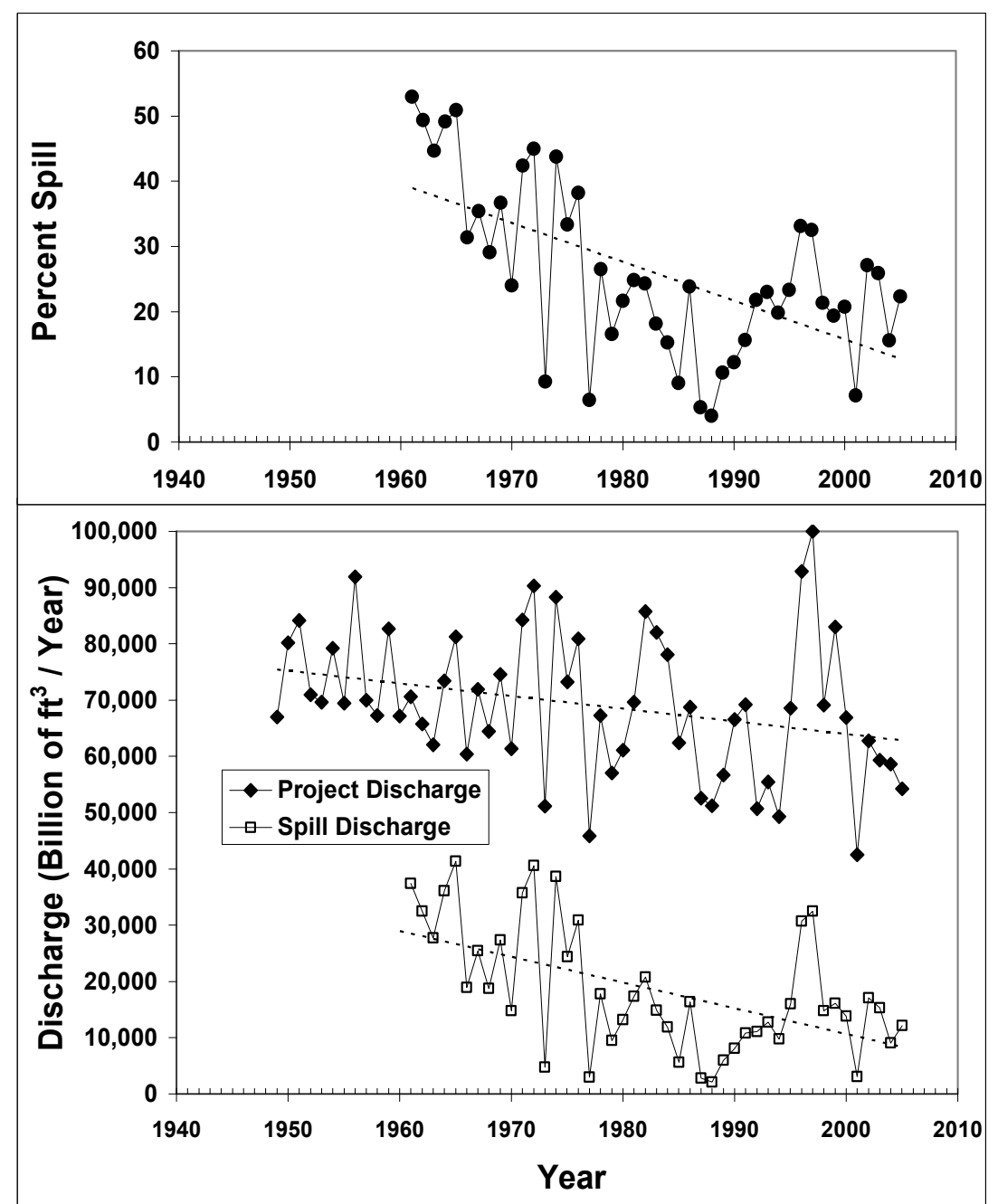

Figure 3.1. Historical Among-Year Trends in Percent Spill (top) and Project and Spill Discharge (bottom) at Bonneville Dam through 2005. Percent spill was calculated as spill discharge / total discharge for the entire year and therefore is lower than percent spill during the spill season. 
A plot of percent spill, project discharge, and spill discharge during the five years of study provides insight into how the study years differed from each other (Figure 3.2). The drought of 2002 actually began in 2000, as indicated by a steady decline in total project discharge from the start of spring 2000. Percent spill increased during the same period because spill discharge was held relatively constant even though project discharge diminished. The lowest spill discharge occurred during 2001, but percent spill averaged 30\% when there was spill, and this was similar to percent spill during much of 2000, 2002, 2004, and early 2005. The periods of greatest discharge occurred during early spring 2000, and late spring and summer of 2002 (Figure 3.2), although even 2002 was only an average year compared with the historical record (Figure 3.1).

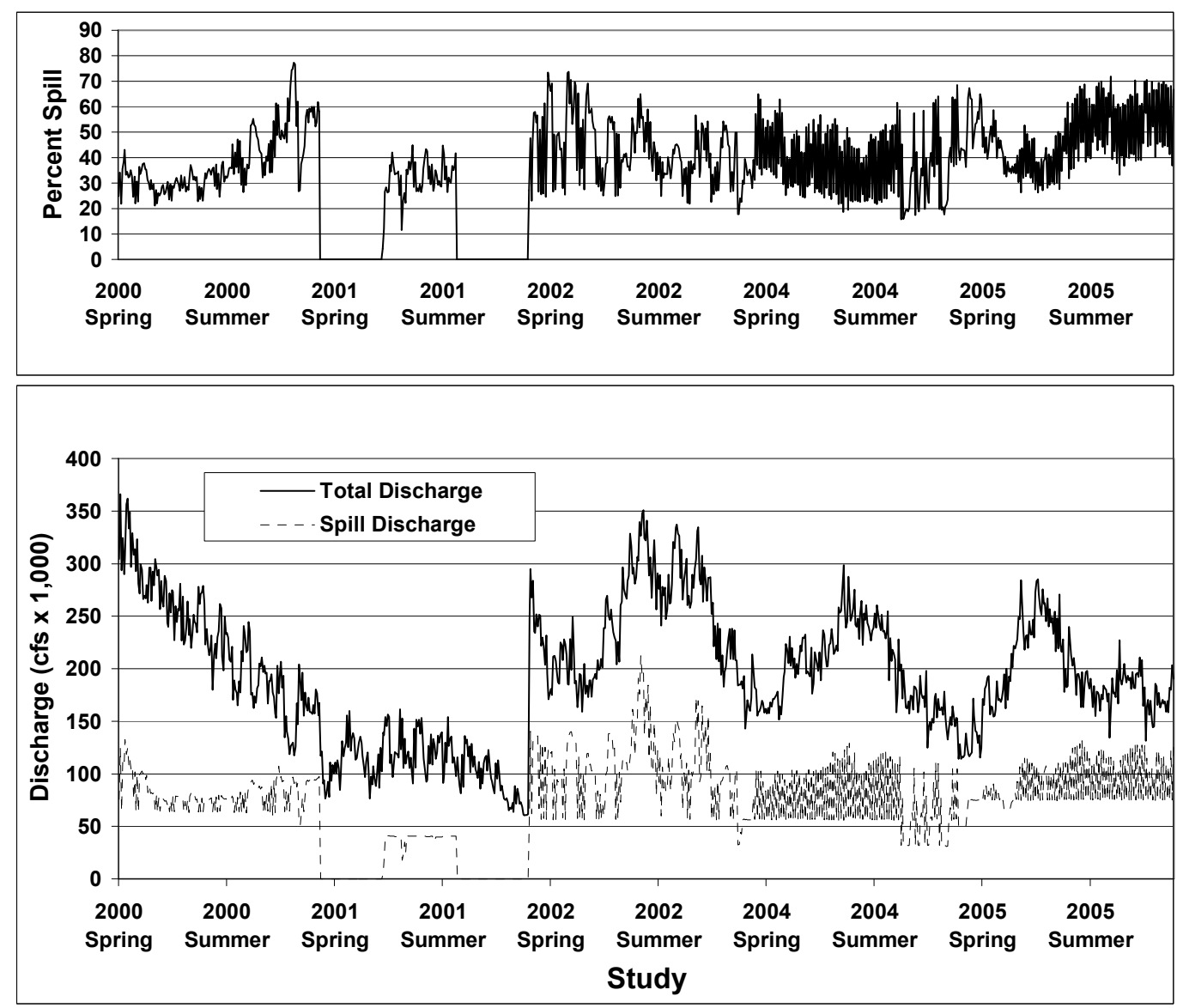

Figure 3.2. Day and Night Estimates of Percent Spill (top), Total Project Discharge, and Spill Discharge during the Five Study Periods. The vertical extent of lines on a given date indicates diel variation in the estimates.

Peaks in migration timing for each species of juvenile salmon may shift by 1-2 weeks depending upon the timing of releases from hatcheries upstream and the magnitude of river discharge, and species composition also may vary widely among years (Figures 3.3 through 3.8). The years 1996, 2001, and 2004 represent very wet, very dry, and average flow conditions for the lower Columbia River, respectively. In 1996, when river discharge and percent spill were both high, the ranking of species by abundance in spring was $42 \%$ sub-yearling Chinook salmon, $28 \%$ coho, $15 \%$ yearling Chinook, $14 \%$ steelhead, and 1\% sockeye (Figure 3.3). In the drought year of 2001, when river discharge and percent 
spill were far below average, the ranking of species by abundance in spring was $42 \%$ coho, $30 \%$ yearling Chinook salmon, only 18\% sub-yearling Chinook salmon, 9\% steelhead, and $<1 \%$ sockeye (Figure 3.5). In 2004, when discharge and percent spill were nearly average, sub-yearling Chinook salmon again dominated the springtime species composition (46\% - Figure 3.7), like they did in 1996 (Figure 3.3). Yearling Chinook salmon were the second most abundance in spring 2004 (30\%), followed by coho $(19 \%)$, a weak run of steelhead (3\%), and a relatively strong run of sockeye $(2 \%)$. These data suggest that reproduction and survival of coho may increase in dry years, whereas sub-yearling Chinook salmon raised in hatcheries do not fare as well during a drought year. Sub-yearling Chinook salmon dominated the summer run all years, making up $86 \%$ of all species in $1996,63 \%$ in 2001 , and $89 \%$ in 2004 . Subyearlings appear to be at a disadvantage during summers of drought. Sockeye percentages were very low in all years except 2002 (the study with the highest discharge), when it made up $9 \%$ of the spring run (Figure 3.6).

Variation in species composition among weeks in spring and among study years (Figure 3.4-3.8) has important implications for acoustic and radio-tagging studies and their conclusions. Neither method provides much statistical inference for the majority of juvenile salmonids migrating in spring, because these yearling Chinook salmon and steelhead made up only $29 \%, 40 \%$, and $33 \%$ of the run in spring 1996, 2001, and 2004, respectively. Results of tagging studies are very useful for assessing speciesspecific effects of structural changes or operations, but they provide no inference for the other species or age groups that make up $61 \%-71 \%$ of the spring run in most years. Tagging of sub-yearling Chinook salmon provides inference for the majority of the juvenile salmonids migrating in summer ( $>86 \%$ of migrants in normal to wet years).

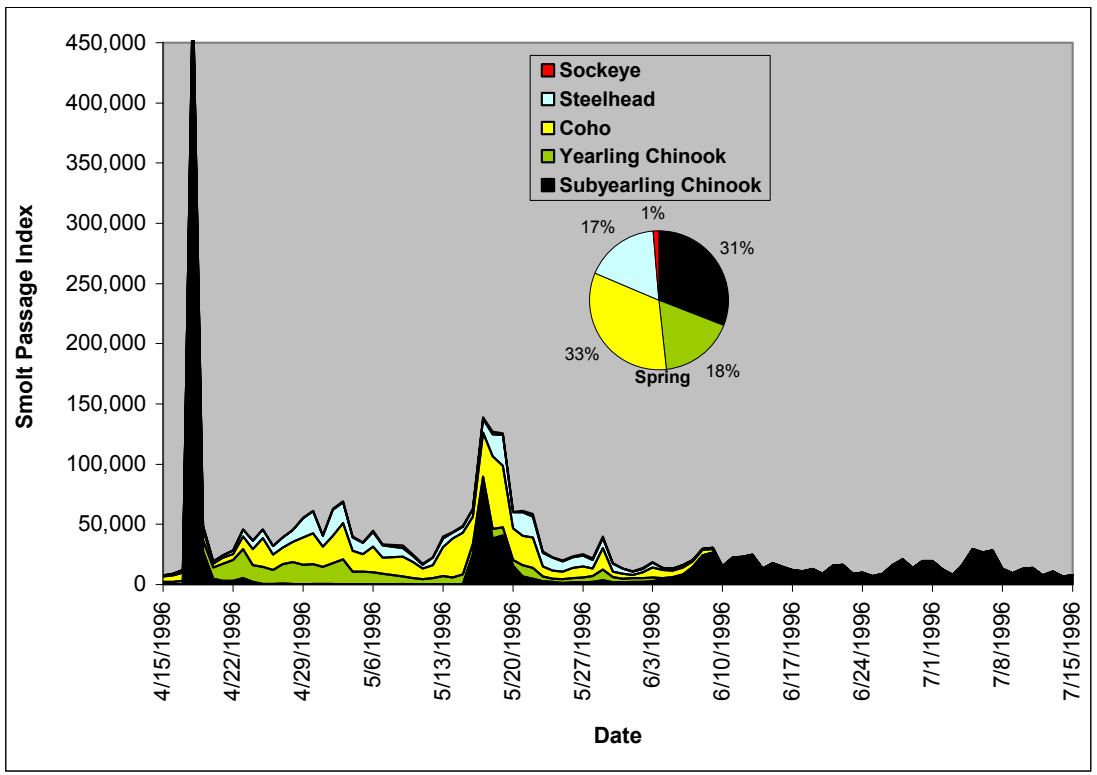

Figure 3.3. Smolt Monitoring Program (SMP) Passage Index for April 15 - July 15, 1996. Based on data from the B2 Juvenile Bypass System. Data were obtained from the DART website (http://www.cqs.washington.edu/dart/pass_com.html). 


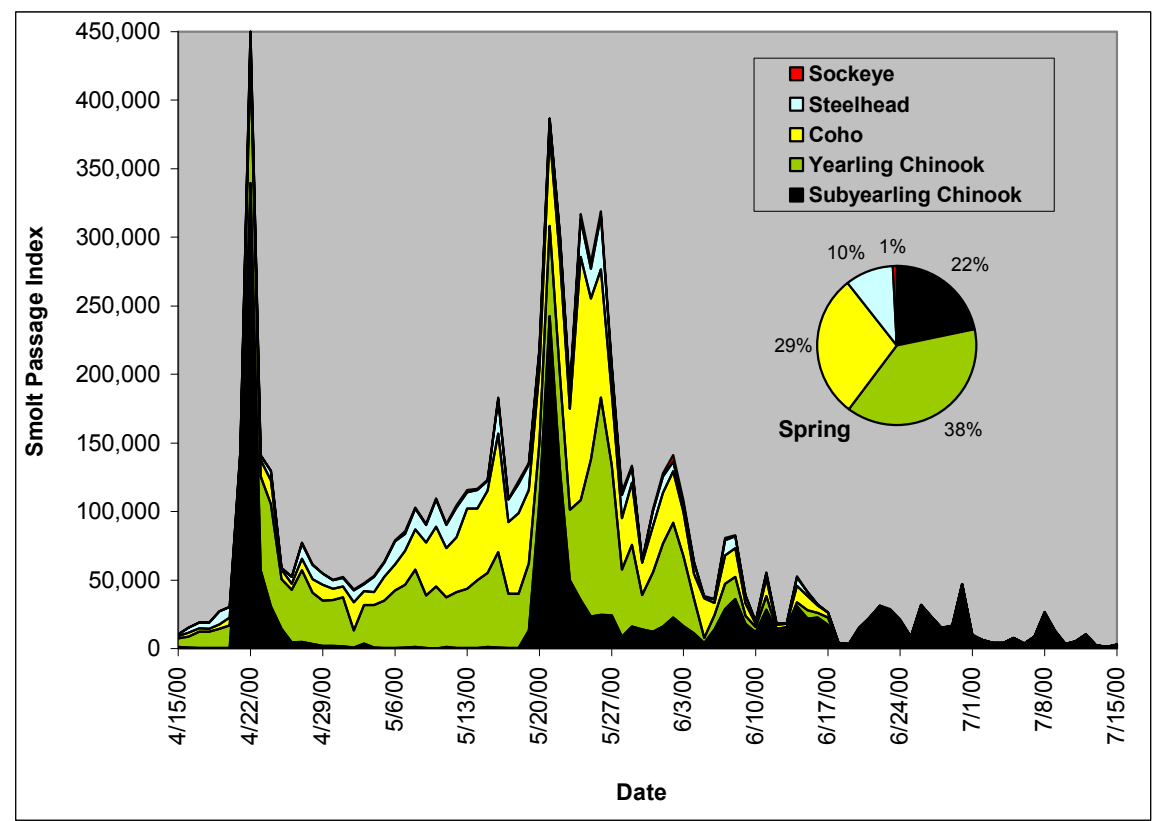

Figure 3.4. Smolt Monitoring Program (SMP) Passage Index for April 15 - July 15, 2000. Based on data from the B2 Juvenile Bypass System. Data were obtained from the DART website (http://www.cqs.washington.edu/dart/pass_com.html).

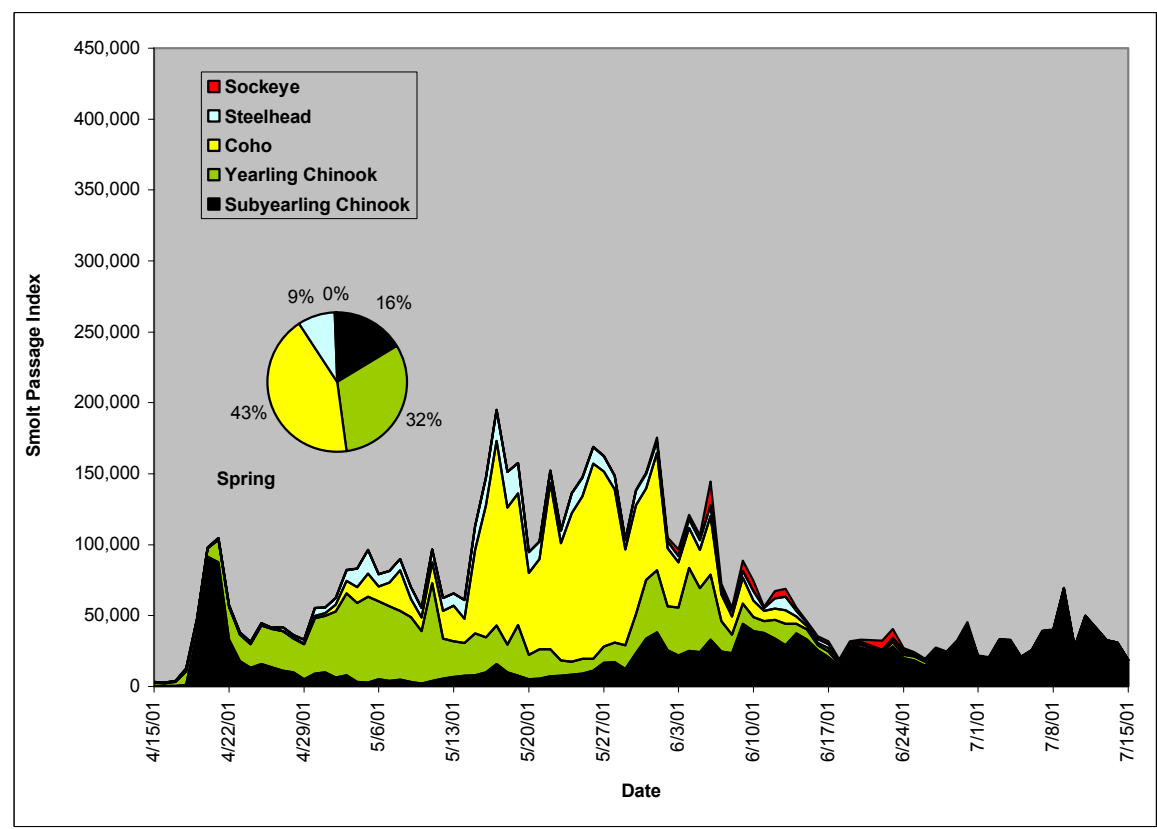

Figure 3.5. Smolt Monitoring Program (SMP) Passage Index for April 15 - July 15, 2001. Based on data from the B2 Juvenile Bypass System. Data were obtained from the DART website (http://www.cqs.washington.edu/dart/pass_com.html). 


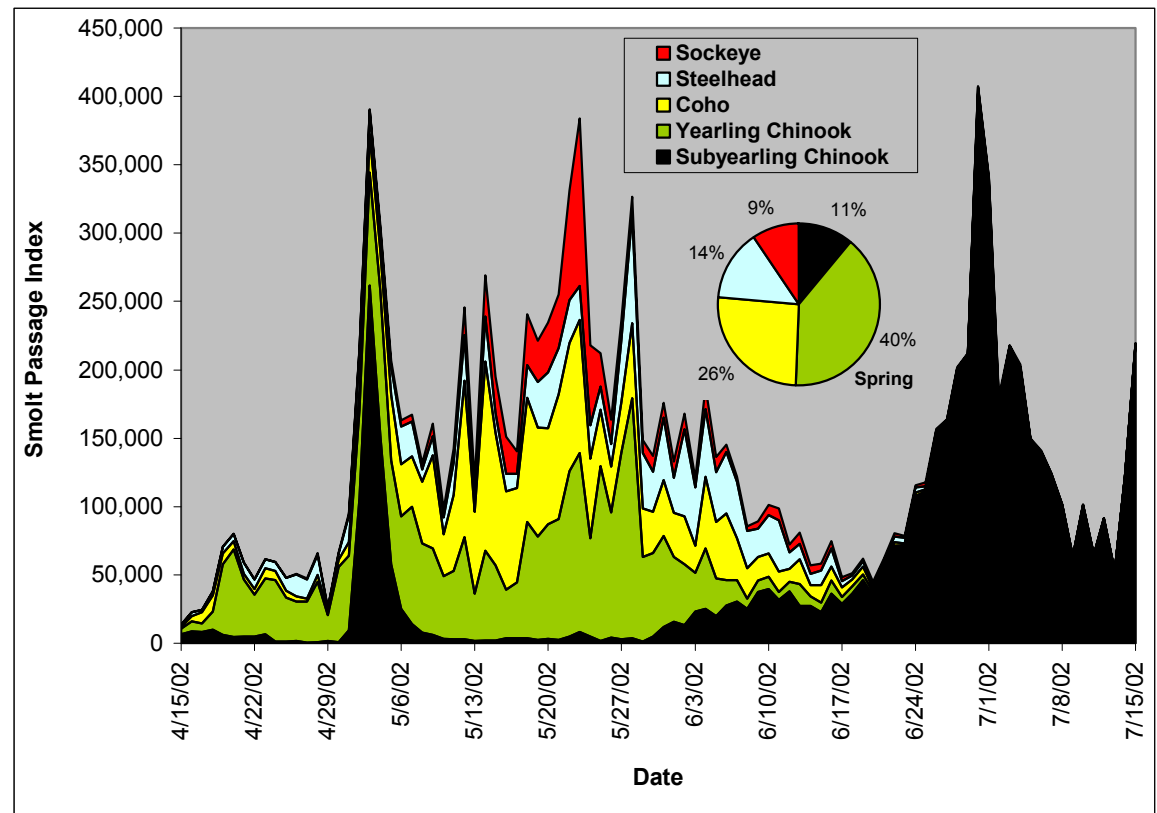

Figure 3.6. Smolt Monitoring Program (SMP) Passage Index for April 15 - July 15, 2002. Based on data from the B2 Juvenile Bypass System. Data were obtained from the DART website (http://www.cqs.washington.edu/dart/pass_com.html).

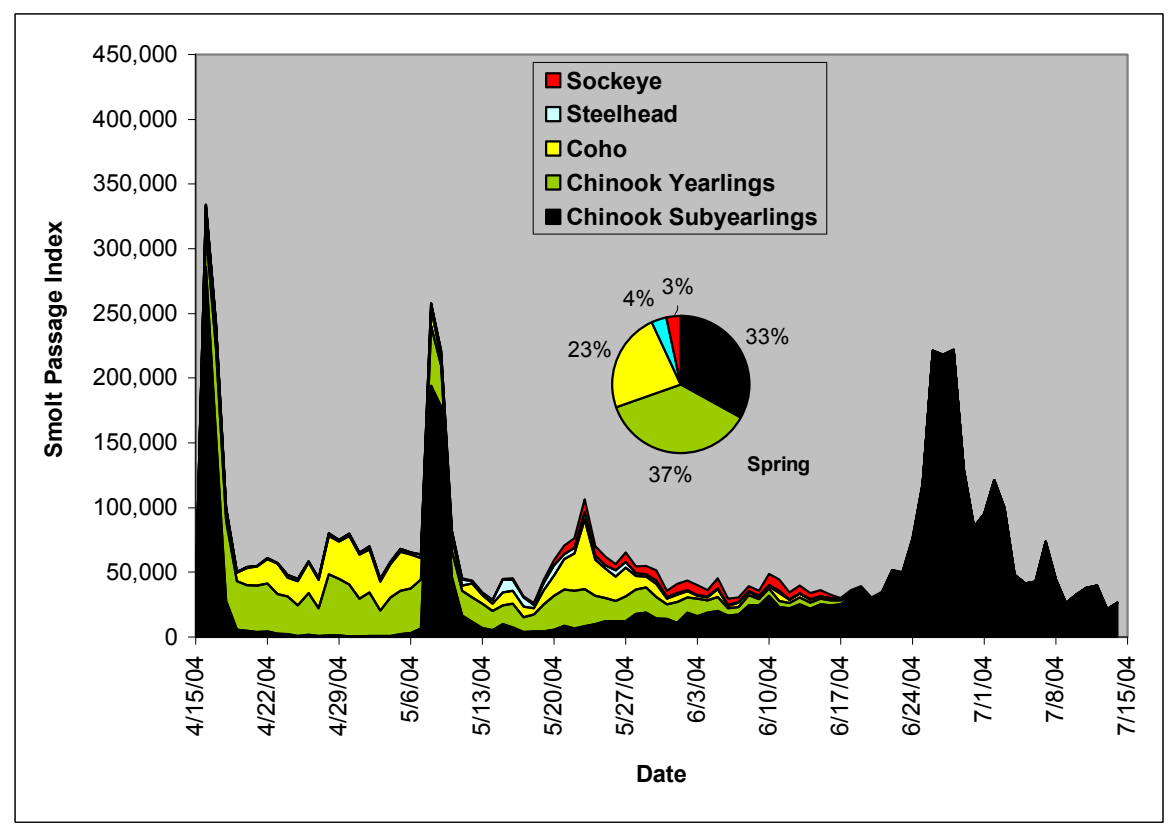

Figure 3.7. Smolt Monitoring Program (SMP) Passage Index for April 15 - July 15, 2004. Based on data from the B2 Juvenile Bypass System. Data were obtained from the DART website (http://www.cqs.washington.edu/dart/pass_com.html). 


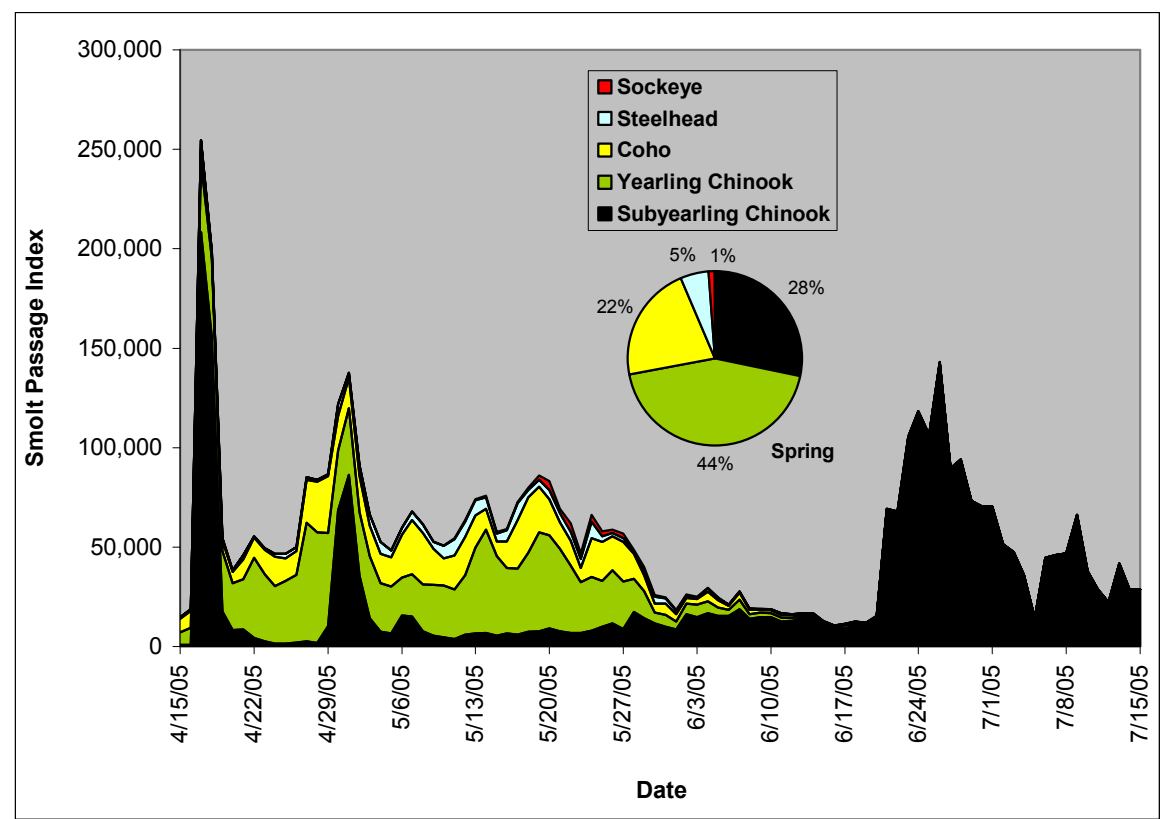

Figure 3.8. Smolt Monitoring Program (SMP) Passage Index for April 15 - July 15, 2005. Based on data from the B2 Juvenile Bypass System. Data were obtained from the DART website (http://www.cqs.washington.edu/dart/pass_com.html).

The typical diel pattern of spill during most study years had strong nighttime peaks associated with spill to the gas cap and daytime valleys of about $75,000 \mathrm{cfs}$, although there were exceptions. For example, during the drought of 2001, the spill season lasted just 20 days in spring and 10 days in summer and when there was spill, it averaged 40,000 cfs 24 hours per day. In summer 2004, there were six days during with spill was held constant at 50,000 cfs (Figure 3.9), and in spring 2005, there were six days during which spill was held constant at about 72,000 cfs during day and night (Figure 3.10).

SEASON $=$ SUMMER

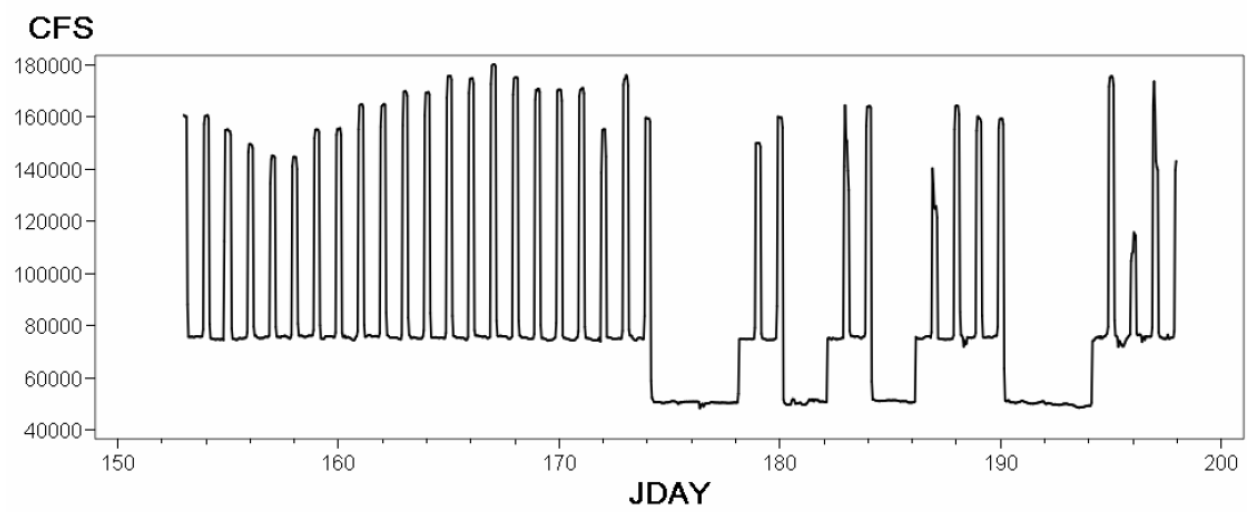

Figure 3.9. Spill Discharge Rate by Date in Summer 2004. Peaks were associated with night spill and the valleys at about 75,000 cfs occurred during the daytime. There were six days of constant 50,000 cfs spill for $24 \mathrm{~h}$ per day. 


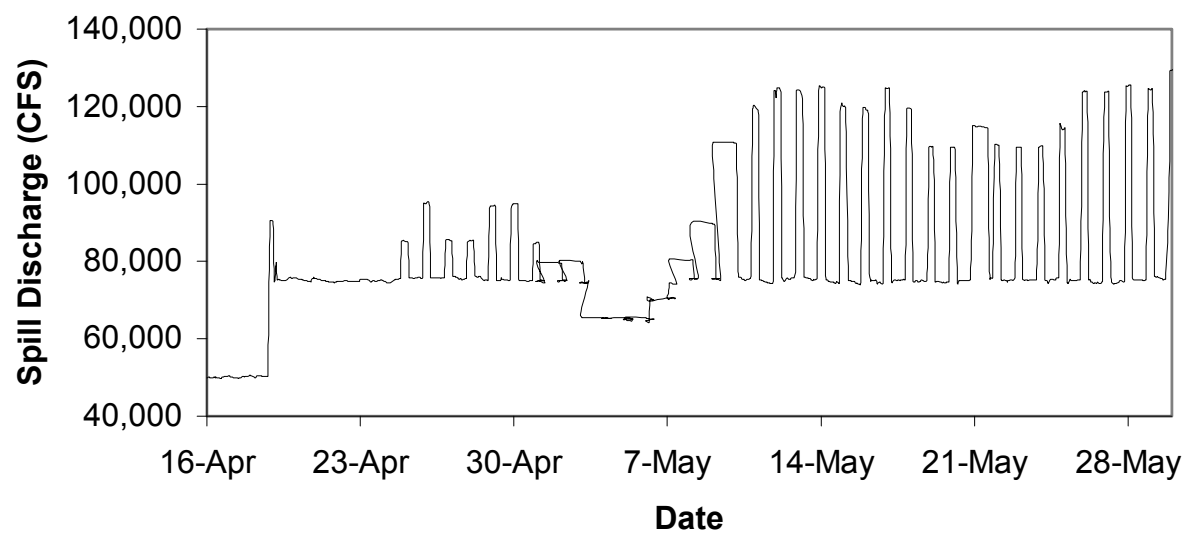

Figure 3.10. Spill Discharge Rate by Date in Spring 2005. Peaks were associated with night spill and the valleys at about $75,000 \mathrm{cfs}$ occurred during the daytime. There were six days of constant 70,000-75,000 cfs spill after April 20.

In spring and summer, turbine discharge typically was greater than or equal to spill discharge during the day and less than or equal to spill discharge at night (e.g., Figure 3.11). Operators usually had to reduce turbine discharge at night to accommodate spill to the gas cap, especially in summer (Figure 3.11), and they did so by shutting down turbines.
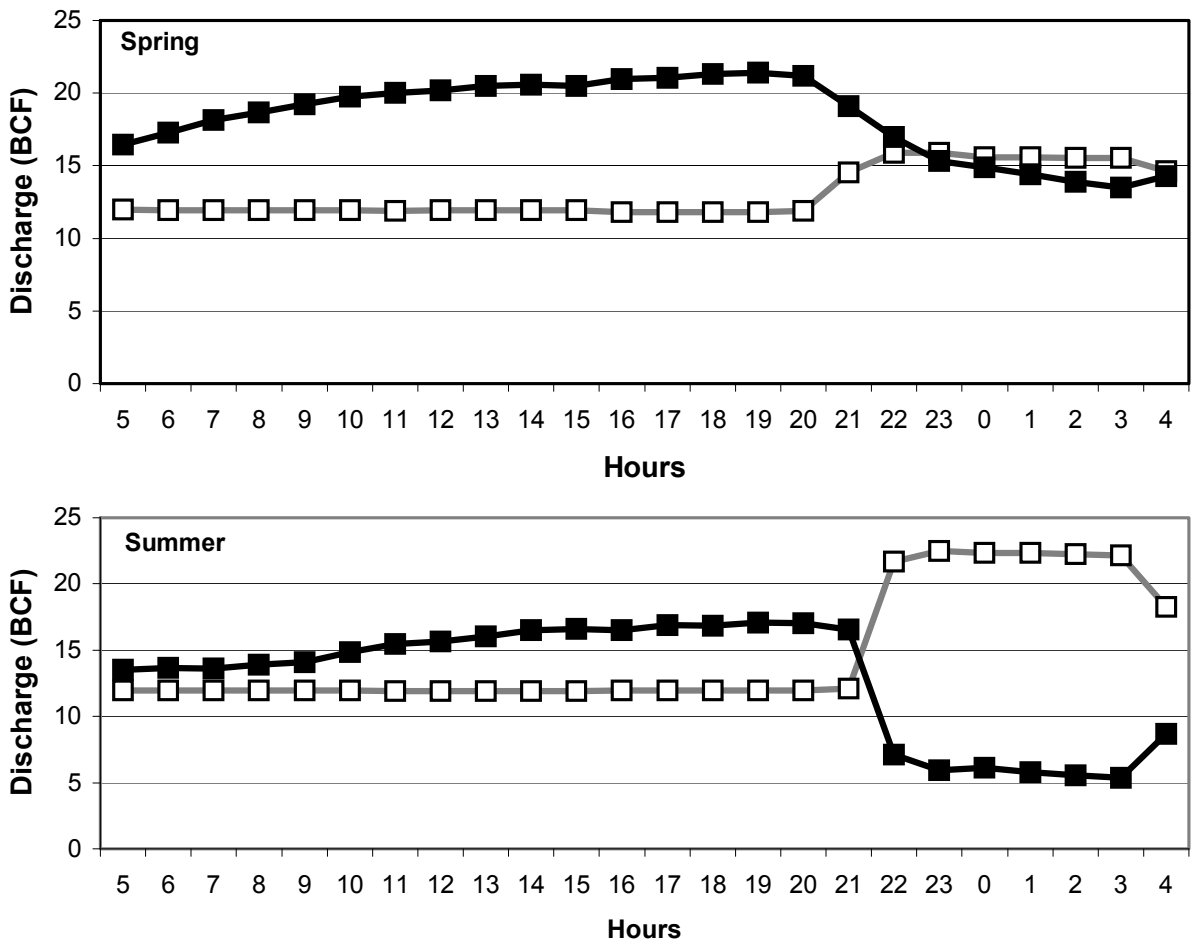

Figure 3.11. Mean Hourly Spill (white squares) and Turbine Discharge (black squares) in Spring and Summer 2005. Discharge in billions of cubic ft (BCF). 


\subsection{Hydroacoustic Detectability}

For study years from 2000 through 2004, hydroacoustic detectability for all passage routes, except the spillway, remained the same as described in the original technical reports (Ploskey et al. 2002a, Ploskey et al. 2002b, Ploskey et al. 2003, Ploskey et al. 2005). However, spatial expansions for spillway passage for 2000, 2001, 2002, and 2004 were scaled upward to account for decreasing detectability with increasing discharge through individual spill bays, similar to what was done to 2005 spillway data (Ploskey et al. 2006). Correction of spillway-discharge and spillway-passage estimates did not improve the fit of the regressions of fish-passage and spill-passage efficiency on percent spill over what was obtained for the uncorrected data (Figure 3.12). In addition, linear regressions explained only $2 \%-3 \%$ less variation than quadratic regressions whether data were corrected or not.
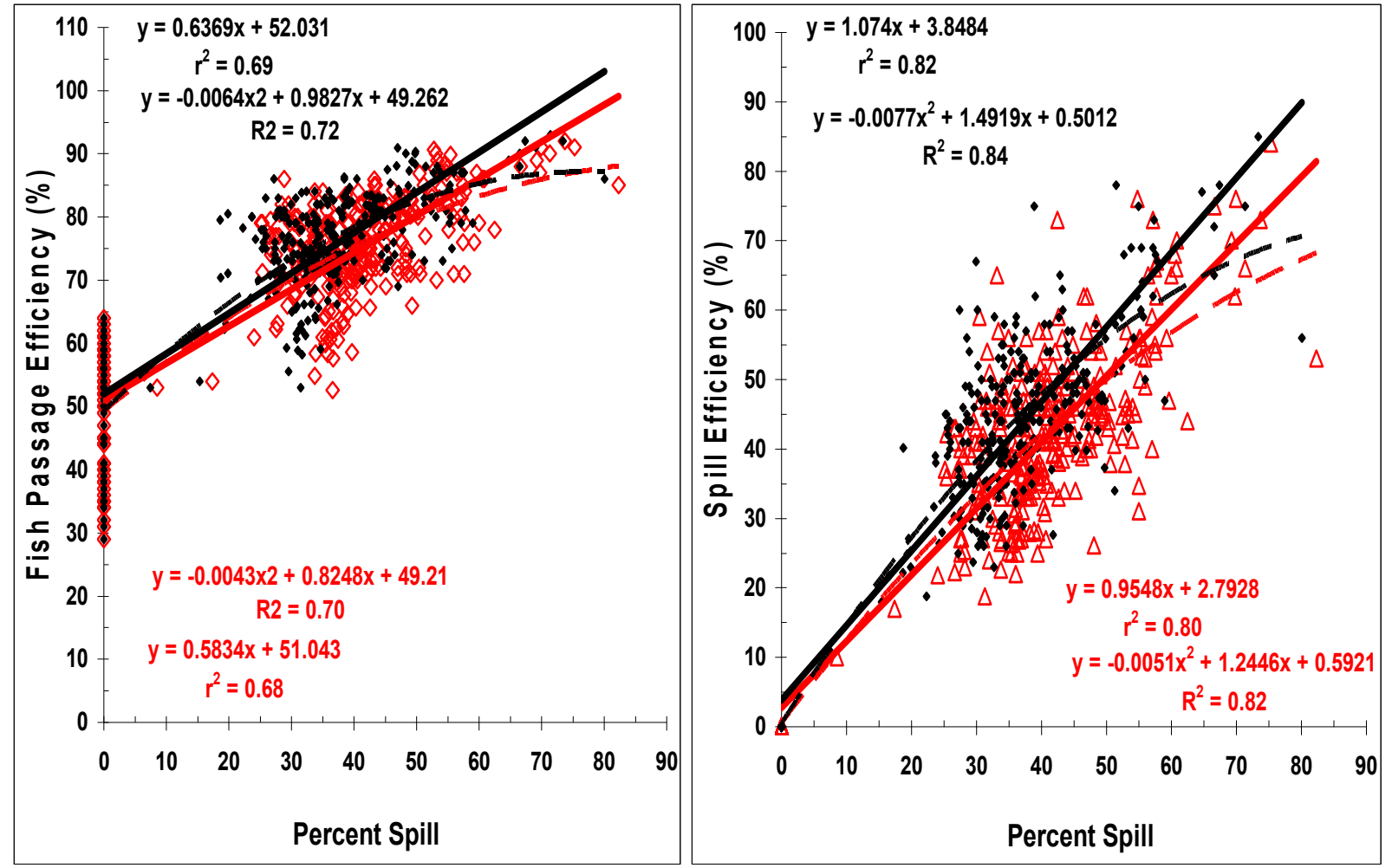

Figure 3.12. Regression of Fish-Passage Efficiency (left) and Spill-Passage Efficiency (right) on Percent Spill Using Corrected (Black) and Uncorrected (red) Data Estimates for 2000, 2001, 2002, and 2004

\subsection{Changes in Metrics after Re-Analysis}

The only fish-passage metrics that changed more than 3\% from original estimates were related to effectiveness, and all changes in efficiency metrics were $\leq 3 \%$ (Tables 3.1 and 3.2). Among the four years of data re-analyzed, percent spill decreased from $0.8 \%$ to $8.2 \%$ in spring and from $1.4 \%$ to $7.5 \%$ in summer (Tables 3.1 and 3.2). Project FPE changed only $0 \%-1 \%$, and changes in spill efficiency ranged from $0.9 \%$ to $2.0 \%$ in all years except in 2000 when it was 3\%. Tables 3.3 and 3.4 show the revised fish passage metrics. 
Table 3.1. Differences in Spring Flow and Fish-Passage Metrics Calculated by Subtracting Previously Reported Estimates from Revised Estimates in this Report. Percent differences also are shown in parentheses for effectiveness metrics. Headings list some important differences in conditions or sampling methods among the years.

\begin{tabular}{|c|c|c|c|c|}
\hline Major Passage Metric & $\begin{array}{c}2000 \\
\text { PSC at Units 1-6 } \\
\text { B1 Priority } \\
\text { No Sluiceway } \\
\text { Sampled; } \\
\text { No STS in PSC } \\
\text { STS in 7-10 }\end{array}$ & $\begin{array}{c}2001 \\
\text { Severe Drought; } \\
\text { B2 Priority; } \\
\text { No Sluiceway } \\
\text { Sampled; } \\
\text { B1 Screens } \\
\text { Installed }\end{array}$ & $\begin{array}{c}2002 \\
\text { B2 Priority } \\
\text { B1 Sluiceway } \\
\text { Sampled; } \\
\text { B1 Screens } \\
\text { Installed }\end{array}$ & $\begin{array}{c}2004 \\
\text { B2 Priority } \\
\text { B1 Sluiceway \& } \\
\text { B2CC Sampled } \\
\text { No B1 Screens } \\
\text { Installed }\end{array}$ \\
\hline B1 Percent of Project Flow (\%) & +1.73 & +0.2 & +0.84 & +1.07 \\
\hline B1 Percent of Project Passage (\%) & -1.71 & -0.1 & -0.74 & -0.3 \\
\hline Spillway Percent of Project Flow (\%) & -0.8 & -2.0 & -3.5 & -8.2 \\
\hline Spill Efficiency (Percent of Passage; \%) & +3.0 & +1.0 & +2.0 & +0.9 \\
\hline B2 Percent of Project Flow (\%) & +1.39 & +1.8 & +2.8 & +4.26 \\
\hline B2 Percent of Project Passage (\%) & -0.88 & -0.9 & -1.1 & -0.06 \\
\hline Project FPE (\%) & +1 & 0 & 0 & +1 \\
\hline B1 FPE & 0 & 0 & 0 & 0 \\
\hline B1 FGE (\%) & 0 & 0 & 0 & No STS \\
\hline B2 FGE (\%) & 0 & 0 & 0 & 0 \\
\hline B2 FPE (with B2CC; \%) & No B2CC & No B2CC & No B2CC & -0.04 \\
\hline FPE (B2 + Spillway; \%) & B1 Priority & +0.5 & +0.75 & +0.49 \\
\hline Surface-Passage Efficiency (all; \%) & N/A & $\mathrm{N} / \mathrm{A}$ & 0 & -0.3 \\
\hline Surface Route Percent of Flow (\%) & $\mathrm{N} / \mathrm{A}$ & $\mathrm{N} / \mathrm{A}$ & 0 & +0.27 \\
\hline Project-wide B1 Sluiceway Efficiency (\%) & $\mathrm{N} / \mathrm{A}$ & $\mathrm{N} / \mathrm{A}$ & 0 & -0.1 \\
\hline B1 Sluiceway Efficiency (\% of B1) & $\mathrm{N} / \mathrm{A}$ & N/A & 0 & 0 \\
\hline Project-wide B2CC Efficiency (\%) & $\mathrm{N} / \mathrm{A}$ & $\mathrm{N} / \mathrm{A}$ & $\mathrm{N} / \mathrm{A}$ & -2 \\
\hline B2CC Efficiency (\% of B2) & $\mathrm{N} / \mathrm{A}$ & $\mathrm{N} / \mathrm{A}$ & $\mathrm{N} / \mathrm{A}$ & 0 \\
\hline Spill Effectiveness & $+0.13(9.6 \%)$ & $+0.18(21.4 \%)$ & $+0.13(12.0 \%)$ & $+0.16(16.9 \%)$ \\
\hline Surface-Passage Effectiveness (all) & N/A & $\mathrm{N} / \mathrm{A}$ & $-2.2(-10.1 \%)$ & $-0.6(-9.5 \%)$ \\
\hline Project-wide B1 Sluiceway Effectiveness & N/A & $\mathrm{N} / \mathrm{A}$ & $-2.2(-10.1 \%)$ & $-0.6(-9.5 \%)$ \\
\hline B1 Sluiceway Effectiveness (Re: B1) & $\mathrm{N} / \mathrm{A}$ & $\mathrm{N} / \mathrm{A}$ & 0 & 0 \\
\hline Project-wide B2CC Effectiveness & $\mathrm{N} / \mathrm{A}$ & $\mathrm{N} / \mathrm{A}$ & $\mathrm{N} / \mathrm{A}$ & $-0.5(9.9 \%)$ \\
\hline B2CC Effectiveness (Re: B2) & $\mathrm{N} / \mathrm{A}$ & $\mathrm{N} / \mathrm{A}$ & $\mathrm{N} / \mathrm{A}$ & 0 \\
\hline
\end{tabular}


Table 3.2. Differences in Summer Flow and Fish-Passage Metrics Calculated by Subtracting Previously Reported Estimates from Revised Estimates in this Report. Percent differences also are shown in parentheses for effectiveness metrics. Headings list some important differences in conditions or sampling methods among the years.

\begin{tabular}{|c|c|c|c|c|}
\hline Major Passage Metric & $\begin{array}{c}2000 \\
\text { PSC at Units 1-6 } \\
\text { B1 Priority } \\
\text { No Sluiceway } \\
\text { Sampled; } \\
\text { No STS in PSC } \\
\text { STS in 7-10 }\end{array}$ & $\begin{array}{c}2001 \\
\text { Severe Drought; } \\
\text { B2 Priority; } \\
\text { No Sluiceway } \\
\text { Sampled; } \\
\\
\text { B1 Screens } \\
\text { Installed }\end{array}$ & $\begin{array}{c}2002 \\
\text { B2 Priority } \\
\text { B1 Sluiceway } \\
\text { Sampled; } \\
\text { B1 Screens } \\
\text { Installed }\end{array}$ & $\begin{array}{c}2004 \\
\text { B2 Priority } \\
\text { B1 Sluiceway \& } \\
\text { B2CC Sampled } \\
\text { No B1 Screens }\end{array}$ \\
\hline B1 Percent of Project Flow (\%) & +7.73 & +0.1 & +1.24 & +1.18 \\
\hline B1 Percent of Project Passage (\%) & -2.54 & -0.1 & -2.15 & -0.3 \\
\hline Spillway Percent of Project Flow (\%) & -7.5 & -1.4 & -3.2 & -5.7 \\
\hline Spill Efficiency (Percent of Passage; \%) & +2.82 & +1.9 & +3 & +0.9 \\
\hline B2 Percent of Project Flow (\%) & -0.25 & +1.3 & +2.02 & +4.52 \\
\hline B2 Percent of Project Passage (\%) & -0.41 & -1.4 & -1.2 & -1.1 \\
\hline Project FPE (\%) & +1 & +1 & +2 & +0.96 \\
\hline B1 FPE & 0 & 0 & 0 & -0.04 \\
\hline B1 FGE (\%) & 0 & 0 & 0 & No STS \\
\hline B2 FGE (\%) & 0 & 0 & 0 & +0.4 \\
\hline B2 FPE (with B2CC; \%) & No B2CC & No B2CC & No B2CC & -0.12 \\
\hline FPE (B2 + Spillway; \%) & B1 Priority & +0.7 & +1.99 & +0.74 \\
\hline Surface Route Percent of Flow (\%) & $\mathrm{N} / \mathrm{A}$ & $\mathrm{N} / \mathrm{A}$ & +0.02 & +0.31 \\
\hline Surface-Passage Efficiency (all; \%) & $\mathrm{N} / \mathrm{A}$ & $\mathrm{N} / \mathrm{A}$ & -1.0 & -0.6 \\
\hline Project-wide B1 Sluiceway Efficiency (\%) & $\mathrm{N} / \mathrm{A}$ & $\mathrm{N} / \mathrm{A}$ & -1.0 & -0.2 \\
\hline B1 Sluiceway Efficiency (\% of B1) & $\mathrm{N} / \mathrm{A}$ & $\mathrm{N} / \mathrm{A}$ & +0.04 & -0.04 \\
\hline Project-wide B2CC Efficiency (\%) & $\mathrm{N} / \mathrm{A}$ & $\mathrm{N} / \mathrm{A}$ & $\mathrm{N} / \mathrm{A}$ & -0.4 \\
\hline B2CC Efficiency (Re: B2) & $\mathrm{N} / \mathrm{A}$ & $\mathrm{N} / \mathrm{A}$ & $\mathrm{N} / \mathrm{A}$ & -0.02 \\
\hline Spill Effectiveness (\%) & $+0.18(17.5 \%)$ & $+0.42(23.0 \%)$ & $+0.16(16.7 \%)$ & $+0.186(22.3 \%)$ \\
\hline Surface-Passage Effectiveness (all; \%) & $\mathrm{N} / \mathrm{A}$ & $\mathrm{N} / \mathrm{A}$ & $-5.1(-10.7 \%)$ & $-0.9(-10.2 \%)$ \\
\hline Project-wide B1 Sluiceway Effectiveness (\%) & $\mathrm{N} / \mathrm{A}$ & $\mathrm{N} / \mathrm{A}$ & $-2.2(10.7 \%)$ & $-1.2(-9.9 \%)$ \\
\hline B1 Sluiceway Effectiveness (Re: B1; \%) & $\mathrm{N} / \mathrm{A}$ & $\mathrm{N} / \mathrm{A}$ & 0.0 & 0.0 \\
\hline Project-wide B2CC Effectiveness (\%) & $\mathrm{N} / \mathrm{A}$ & N/A & $\mathrm{N} / \mathrm{A}$ & $-0.9(-10.6 \%)$ \\
\hline B2CC Effectiveness (Re: B2; \%) & $\mathrm{N} / \mathrm{A}$ & $\mathrm{N} / \mathrm{A}$ & $\mathrm{N} / \mathrm{A}$ & -0.01 \\
\hline
\end{tabular}


Table 3.3. Estimates of Major Flow and Passage Metrics $\pm 1 / 295 \%$ Confidence Limits for Spring Based upon Hydroacoustic Sampling in 2000, 2001, 2002, 2004, and 2005. Headings list some important differences in conditions or sampling methods among years.

\begin{tabular}{|c|c|c|c|c|c|}
\hline Major Passage Metric & $\begin{array}{c}2000 \\
\text { PSC at Units 1-6 } \\
\text { B1 Priority } \\
\text { No Sluiceway } \\
\text { Sampled; } \\
\text { No STS in PSC } \\
\text { STS in 7-10 }\end{array}$ & $\begin{array}{c}2001 \\
\text { Severe Drought; } \\
\text { B2 Priority; } \\
\text { No Sluiceway } \\
\text { Sampled; } \\
\\
\text { B1 Screens } \\
\text { Installed }\end{array}$ & $\begin{array}{c}2002 \\
\text { B2 Priority } \\
\text { B1 Sluiceway } \\
\text { Sampled; } \\
\text { B1 Screens } \\
\text { Installed }\end{array}$ & $\begin{array}{c}2004 \\
\text { B2 Priority } \\
\text { B1 Sluiceway \& } \\
\text { B2CC Sampled } \\
\text { No B1 Screens }\end{array}$ & $\begin{array}{c}2005 \\
\text { B2 Priority } \\
\text { B1 Sluiceway \& } \\
\text { B2CC Sampled } \\
\text { No B1 Screens }\end{array}$ \\
\hline B1 Percent of Project Flow & $37.8 \%$ & $7.5 \%$ & $12.3 \%$ & $12.6 \%$ & $11.6 \%$ \\
\hline B1 Percent of Project Passage & $33.2 \%$ & $6.8 \%$ & $17.9 \%$ & $16.8 \pm 0.9 \%$ & $16.3 \pm 0.6 \%$ \\
\hline Spillway Percent of Project Flow & $31.5 \%$ & $14.7 \%$ & $44.6 \%$ & $33.5 \%$ & $40.3 \%$ \\
\hline Spill Efficiency (Percent of Passage) & $47 \pm 0.1 \%$ & $15.0 \pm 0.2 \%$ & $54.0 \pm 0.5 \%$ & $41.2 \pm 0.9 \%$ & $39.7 \pm 1.1 \%$ \\
\hline B2 Percent of Project Flow & $32.1 \%$ & $78.2 \%$ & $42.6 \%$ & $51 \%$ & $48.2 \%$ \\
\hline B2 Percent of Project Passage & $20.3 \%$ & $78.5 \%$ & $27.9 \%$ & $42.0 \pm 1.2 \%$ & $44.1 \pm 1.6 \%$ \\
\hline Project FPE & $80 \pm 0.1 \%$ & $63 \pm 0.3 \%$ & $79 \pm 0.1 \%$ & $74 \pm 1.2 \%$ & $73.4 \pm 2.0 \%$ \\
\hline B1 FPE & $67 \pm 0.1 \%$ & $49 \pm 2.3 \%$ & $58 \pm 0.4 \%$ & $33.3 \pm 2.0 \%$ & $37.4 \pm 0.8 \%$ \\
\hline B1 FGE & $54 \pm 0.1 \%$ & $49 \pm 2.3 \%$ & $37 \pm 0.4 \%$ & $\mathrm{~N} / \mathrm{A}$ & $\mathrm{N} / \mathrm{A}$ \\
\hline B2 FGE & $55 \pm 0.1 \%$ & $57 \pm 0.3 \%$ & $53 \pm 0.3 \%$ & $48 \pm 3.3 \%$ & $45.0 \pm 4.3 \%$ \\
\hline B2 FPE (with B2CC) & N/A (No B2CC) & N/A (No B2CC) & N/A (No B2CC) & $64.0 \pm 2.1 \%$ & $62.8 \pm 3.9 \%$ \\
\hline FPE (B2 + Spillway) & N/A (B2 Priority) & $64 \pm 0.3 \%$ & $84 \pm 0.1 \%$ & $82 \pm 0.01 \%$ & $80.4 \pm 0.1 \%$ \\
\hline Surface-Passage Efficiency (all) & $\mathrm{N} / \mathrm{A}$ & $\mathrm{N} / \mathrm{A}$ & $6.0 \pm 0.1 \%$ & $18.8 \pm 0.4 \%$ & $20.2 \pm 0.6 \%$ \\
\hline Surface Route Percent of Flow & $\mathrm{N} / \mathrm{A}$ & $N / A$ & 0.03 & $3.3 \%$ & $3.2 \%$ \\
\hline Project-wide B1 Sluiceway Efficiency & $\mathrm{N} / \mathrm{A}$ & $\mathrm{N} / \mathrm{A}$ & 5.9 & $5.6 \pm 0.1 \%$ & $6.08 \pm 0.2 \%$ \\
\hline B1 Sluiceway Efficiency (\% of B1) & $\mathrm{N} / \mathrm{A}$ & $\mathrm{N} / \mathrm{A}$ & $33.2 \pm 0.9 \%$ & $33.3 \pm 2.0 \%$ & $37.4 \pm 0.8 \%$ \\
\hline Project-wide B2CC Efficiency & $N / A$ & $\mathrm{~N} / \mathrm{A}$ & $N / A$ & $13.2 \pm 0.3 \%$ & $14.1 \pm 0.4 \%$ \\
\hline B2CC Efficiency (\% of B2) & $\mathrm{N} / \mathrm{A}$ & $\mathrm{N} / \mathrm{A}$ & $\mathrm{N} / \mathrm{A}$ & $31.4 \pm 1.4 \%$ & $31.9 \pm 2.0 \%$ \\
\hline Spill Effectiveness & $1.49 \pm 0.01$ & $1.02 \pm 0.00$ & $1.21 \pm 0.01$ & $1.13 \pm 0.03$ & $0.98 \pm 0.03$ \\
\hline Surface-Passage Effectiveness (all) & $\mathrm{N} / \mathrm{A}$ & $\mathrm{N} / \mathrm{A}$ & $19.7 \pm 0.01$ & $5.7 \pm 0.12$ & $6.3 \pm 0.18$ \\
\hline $\begin{array}{l}\text { Project-wide B1 Sluiceway } \\
\text { Effectiveness }\end{array}$ & $\mathrm{N} / \mathrm{A}$ & $\mathrm{N} / \mathrm{A}$ & $19.7 \pm 0.01$ & $10.1 \pm 0.23$ & $10.7 \pm 0.3$ \\
\hline B1 Sluiceway Effectiveness (Re: B1) & $\mathrm{N} / \mathrm{A}$ & $\mathrm{N} / \mathrm{A}$ & $13.5 \pm 0.06$ & $7.6 \pm 0.5$ & $7.6 \pm 0.2$ \\
\hline Project-wide B2CC Effectiveness & $\mathrm{N} / \mathrm{A}$ & $\mathrm{N} / \mathrm{A}$ & $\mathrm{N} / \mathrm{A}$ & $4.8 \pm 0.1$ & $5.3 \pm 0.2$ \\
\hline B2CC Effectiveness (Re: B2) & $\mathrm{N} / \mathrm{A}$ & $\mathrm{N} / \mathrm{A}$ & $\mathrm{N} / \mathrm{A}$ & $5.8 \pm 0.03$ & $5.8 \pm 0.4$ \\
\hline
\end{tabular}


Table 3.4. Estimates of Major Flow and Passage Metrics $\pm 1 / 295 \%$ Confidence Limits for Summer Based upon Hydroacoustic Sampling in 2000, 2001, 2002, 2004, and 2005. Headings list some important differences in conditions or sampling methods among years.

\begin{tabular}{|c|c|c|c|c|c|}
\hline Major Passage Metric & $\begin{array}{c}2000 \\
\text { PSC at Units 1-6 } \\
\text { B1 Priority } \\
\text { No Sluiceway } \\
\text { Sampled; } \\
\text { No STS in PSC } \\
\text { STS in 7-10 }\end{array}$ & $\begin{array}{c}2001 \\
\text { Severe Drought; } \\
\text { B2 Priority; } \\
\text { No Sluiceway } \\
\text { Sampled; } \\
\\
\text { B1 Screens } \\
\text { Installed }\end{array}$ & $\begin{array}{c}2002 \\
\text { B2 Priority } \\
\text { B1 Sluiceway } \\
\text { Sampled; } \\
\text { B1 Screens } \\
\text { Installed }\end{array}$ & $\begin{array}{c}2004 \\
\text { B2 Priority } \\
\text { B1 Sluiceway \& } \\
\text { B2CC Sampled } \\
\text { No B1 Screens }\end{array}$ & $\begin{array}{c}2005 \\
\text { B2 Priority } \\
\text { B1 Sluiceway \& } \\
\text { B2CC Sampled } \\
\text { No B1 Screens }\end{array}$ \\
\hline B1 Percent of Project Flow & $48.9 \%$ & $8.7 \%$ & $22.0 \%$ & $13.5 \%$ & $3.7 \%$ \\
\hline B1 Percent of Project Passage & 40.9 & $7.4 \%$ & $34.7 \%$ & $15.8 \%$ & $7.2 \pm 0.3 \%$ \\
\hline Spillway Percent of Project Flow & $43 \%$ & $9.8 \%$ & $40.2 \%$ & $33.5 \%$ & $51.6 \%$ \\
\hline Spill Efficiency (Percent of Passage) & $52.0 \pm 0.2 \%$ & $22.0 \pm 0.3 \%$ & $45.0 \pm 0.6 \%$ & $34.1 \pm 0.7 \%$ & $44.2 \pm 1.3 \%$ \\
\hline B2 Percent of Project Flow & $10.1 \%$ & $81.7 \%$ & 37.2 & $53.0 \%$ & $44.8 \%$ \\
\hline B2 Percent of Project Passage & $6.8 \%$ & $71.0 \%$ & $19.8 \%$ & $50.1 \pm 0.4 \%$ & $48.6 \pm 1.5 \%$ \\
\hline Project FPE & $80 \pm 0.1 \%$ & $54 \pm 0.4 \%$ & $76 \pm 0.2 \%$ & $71 \pm 1.2 \%$ & $81 \pm 2.1 \%$ \\
\hline B1 FPE & $61 \pm 0.1 \%$ & $40 \pm 1.8 \%$ & $61 \pm 0.3 \%$ & $37.6 \pm 1.5 \%$ & $70.9 \pm 1.3 \%$ \\
\hline B1 FGE & $39.0 \pm 0.1 \%$ & $40 \pm 1.8 \%$ & $45 \pm 0.5 \%$ & 0 (No STSs) & 0 (No STSs) \\
\hline B2 FGE & $35 \pm 1 \%$ & $42 \pm 0.4 \%$ & $46 \pm 0.1 \%$ & $36 \pm 2.9 \%$ & $37 \pm 4.4 \%$ \\
\hline B2 FPE (with B2CC) & $\mathrm{N} / \mathrm{A}$ (No B2CC) & $\mathrm{N} / \mathrm{A}$ (No B2CC) & $\mathrm{N} / \mathrm{A}$ (No B2CC) & $61 \pm 2.0 \%$ & $64.63 \pm 3.5 \%$ \\
\hline FPE (B2 + Spillway) & N/A (B2 Priority) & $55 \pm 0.4 \%$ & $84 \pm 0.5 \%$ & $77 \pm 0.02 \%$ & $82 \pm 0.02 \%$ \\
\hline Surface Route Percent of Flow & $\mathrm{N} / \mathrm{A}$ & $\mathrm{N} / \mathrm{A}$ & 0.24 & $3.3 \%$ & $3.5 \%$ \\
\hline Surface-Passage Efficiency (all) & N/A & N/A & $10.0 \pm 0.1 \%$ & $25.8 \pm 0.5 \%$ & $26.2 \pm 0.7 \%$ \\
\hline Project-wide B1 Sluiceway Efficiency & $\mathrm{N} / \mathrm{A}$ & $\mathrm{N} / \mathrm{A}$ & $10.0 \pm 0.1 \%$ & $5.9 \pm 0.1 \%$ & $5.13 \pm 0.2 \%$ \\
\hline B1 Sluiceway Efficiency (\% of B1) & $\mathrm{N} / \mathrm{A}$ & $\mathrm{N} / \mathrm{A}$ & $29.1 \pm 0.7 \%$ & $37.6 \pm 1.5 \%$ & $70.9 \pm 1.2 \%$ \\
\hline Project-wide B2CC Efficiency & N/A & $\mathrm{N} / \mathrm{A}$ & $\mathrm{N} / \mathrm{A}$ & $19.9 \pm 0.4 \%$ & $21.1 \pm 0.6 \%$ \\
\hline B2CC Efficiency (Re: B2) & $\mathrm{N} / \mathrm{A}$ & $\mathrm{N} / \mathrm{A}$ & $\mathrm{N} / \mathrm{A}$ & $39.6 \pm 1.5 \%$ & $43.5 \pm 2.5 \%$ \\
\hline Spill Effectiveness & $1.21 \pm 0.01$ & $2.25 \pm 0.01$ & $1.12 \pm 0.01$ & $1.02 \pm 0.02$ & $0.86 \pm 0.03$ \\
\hline Surface-Passage Effectiveness (all) & $\mathrm{N} / \mathrm{A}$ & N/A & $42.8 \pm 0.03$ & $7.9 \pm 0.15$ & $7.60 \pm 0.22$ \\
\hline $\begin{array}{l}\text { Project-wide B1 Sluiceway } \\
\text { Effectiveness }\end{array}$ & $\mathrm{N} / \mathrm{A}$ & $\mathrm{N} / \mathrm{A}$ & $42.8 \pm 0.03$ & $10.9 \pm 0.2$ & $8.6 \pm 0.3$ \\
\hline B1 Sluiceway Effectiveness (Re: B1) & $\mathrm{N} / \mathrm{A}$ & $\mathrm{N} / \mathrm{A}$ & $26.9 \pm 6.6$ & $9.3 \pm 0.4$ & $4.3 \pm 0.08$ \\
\hline Project-wide B2CC Effectiveness & $N / A$ & $\mathrm{~N} / \mathrm{A}$ & $\mathrm{N} / \mathrm{A}$ & $7.3 \pm 0.14$ & $7.4 \pm 0.21$ \\
\hline B2CC Effectiveness (Re: B2) & $\mathrm{N} / \mathrm{A}$ & $\mathrm{N} / \mathrm{A}$ & $\mathrm{N} / \mathrm{A}$ & $7.7 \pm 0.28$ & $6.8 \pm 0.4$ \\
\hline
\end{tabular}

Re-analysis produced spill effectiveness estimates that ranged from $12 \%$ to $21 \%$ higher than previous estimates in spring (Figure 3.13) and 16.7\% to 27.5\% higher in summer (Figure 3.14), but the 
mean spill effectiveness over all years was only slightly above 1:1 (1.17 for spring and 1.29 for summer). Very tight and non-overlapping $95 \%$ confidence limits suggest that observed differences were significant.

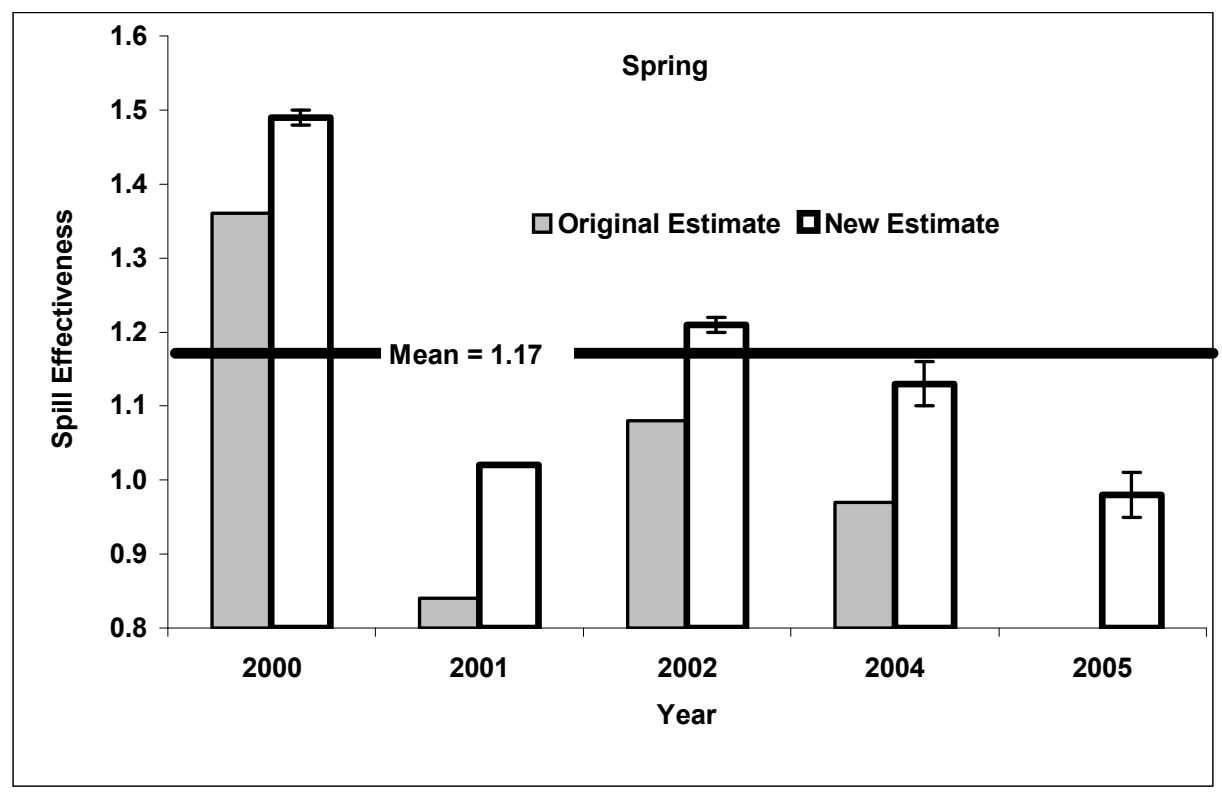

Figure 3.13. Bar Chart Showing Original and Revised Estimates in Spring Spill Effectiveness from 2000 through 2004. The horizontal line represents the mean spill effectiveness over the five study years, including 2005 , which was not re-analyzed.

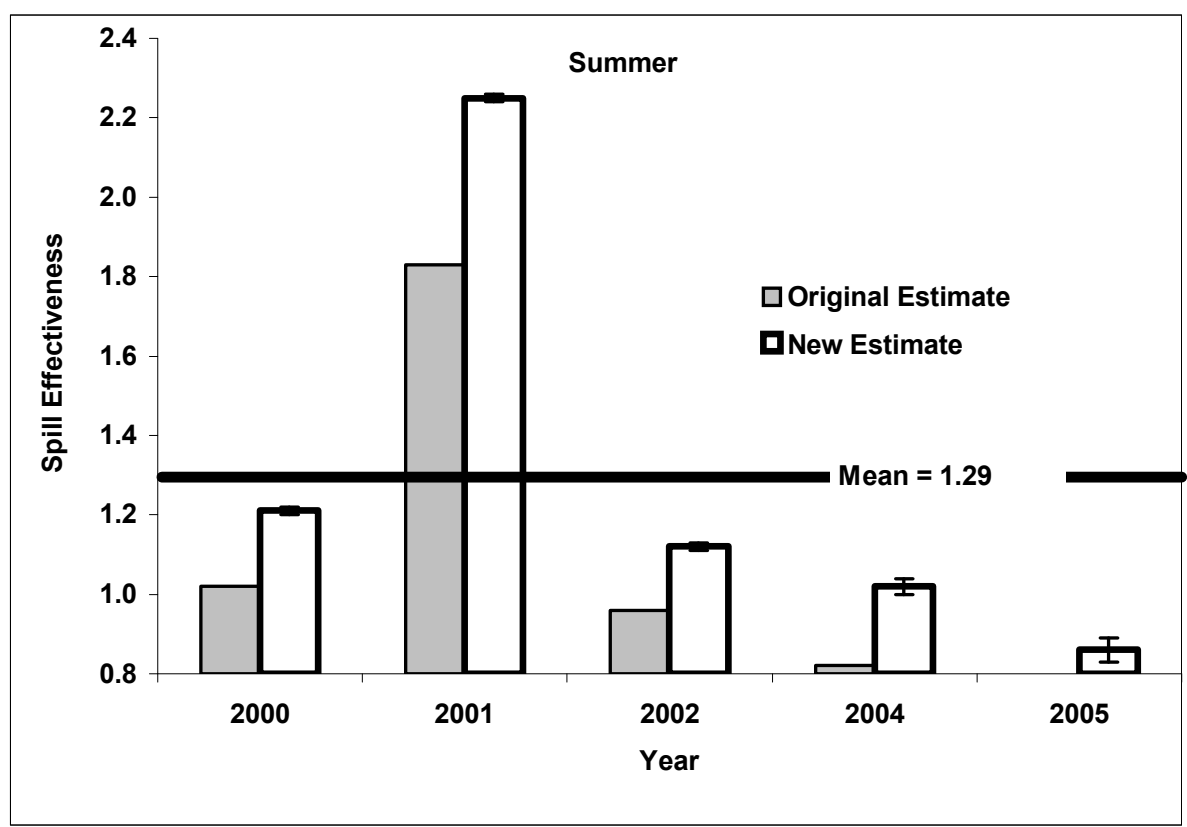

Figure 3.14. Bar Chart Showing Original and Revised Estimates in Summer Spill Effectiveness from 2000 through 2004. The horizontal line represents the mean spill effectiveness over the five study years, including 2005, which was not re-analyzed. 
While re-analysis increased spill effectiveness, it decreased surface-passage effectiveness by $10.1 \%$ in spring and $10.7 \%$ in summer of 2002 and $9.5 \%$ in spring and $10.2 \%$ in summer of 2004 (Figure 3.15). Tight $95 \%$ and non-overlapping confidence limits suggest that observed differences were significant.

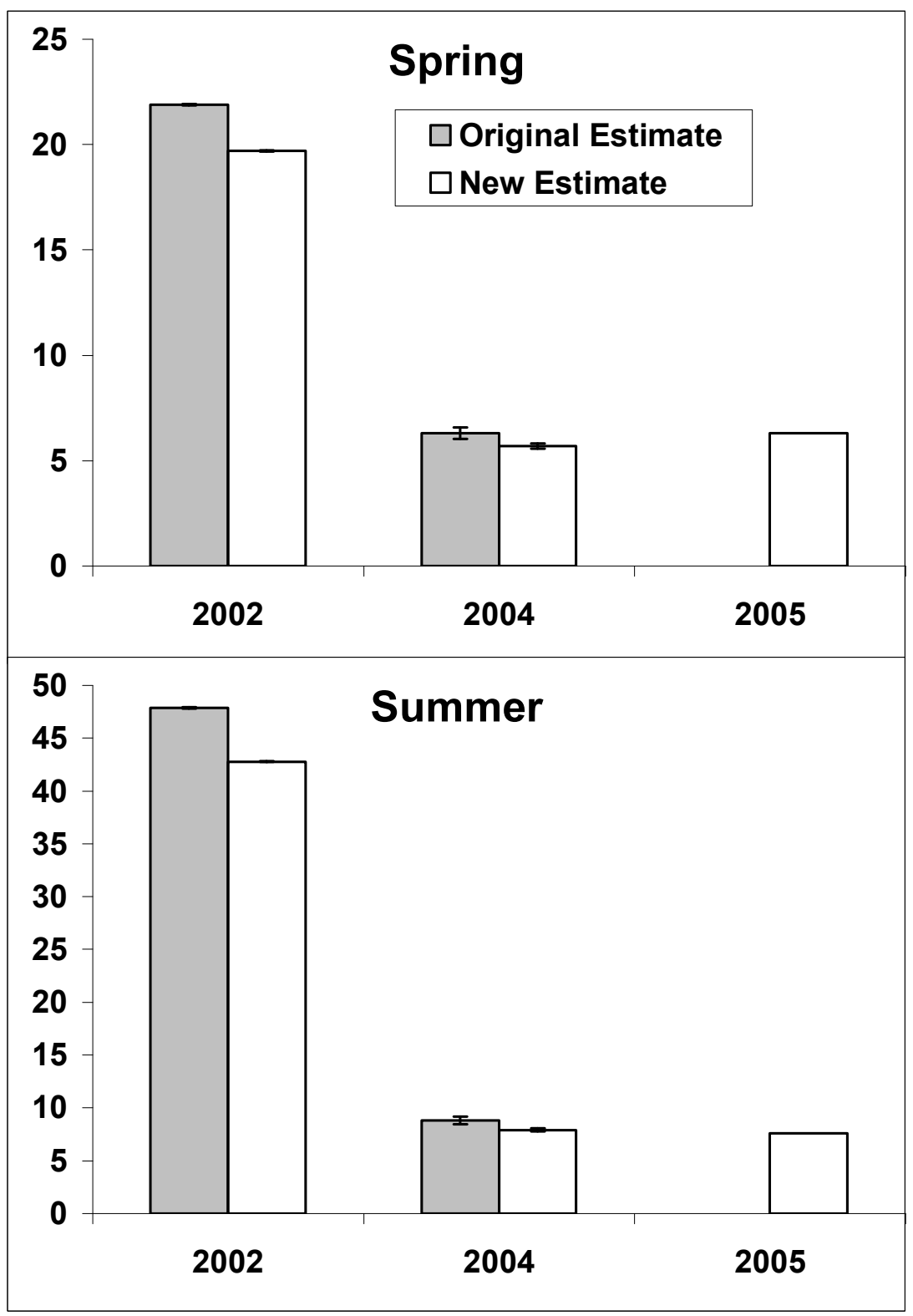

Figure 3.15. Bar Chart Showing the Decrease in Surface-Passage Effectiveness that Resulted from Adjusting Spill Discharge in 2002 and 2004. Vertical bars indicated 95\% confidence intervals on the estimates. 


\subsection{Relations Between Passage Metrics and Percent Flow by Route}

Based upon five years of day and night estimates, percent spill explained only $16 \%$ of the variation in spill passage effectiveness, and the trend was slightly negative (Figure 3.16). Except for the curve for 2000, which explained 58\% of variation, curves for years after 2000 explained only $10 \%$ or less of the variation in spill effectiveness (Figure 3.17).

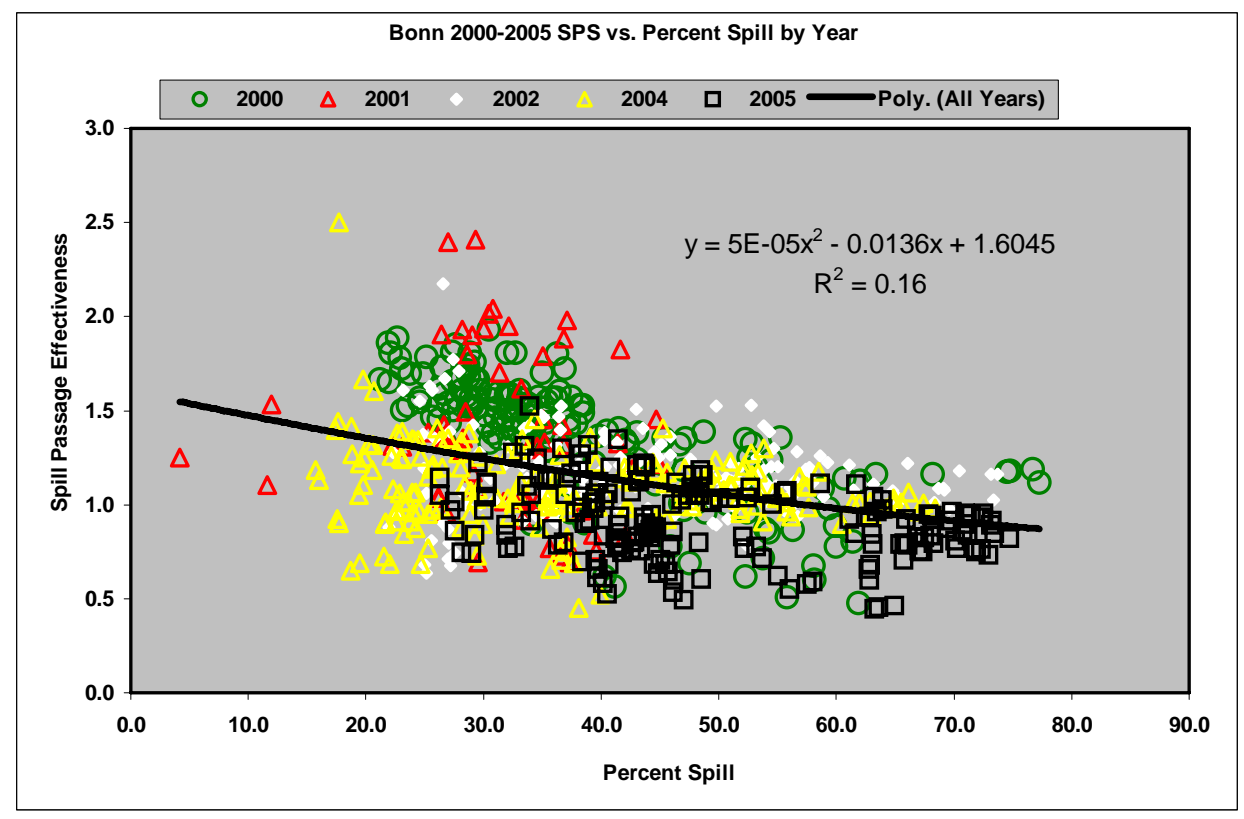

Figure 3.16. Regression of Day and Night Estimates of Spill-Passage Effectiveness on Percent Spill

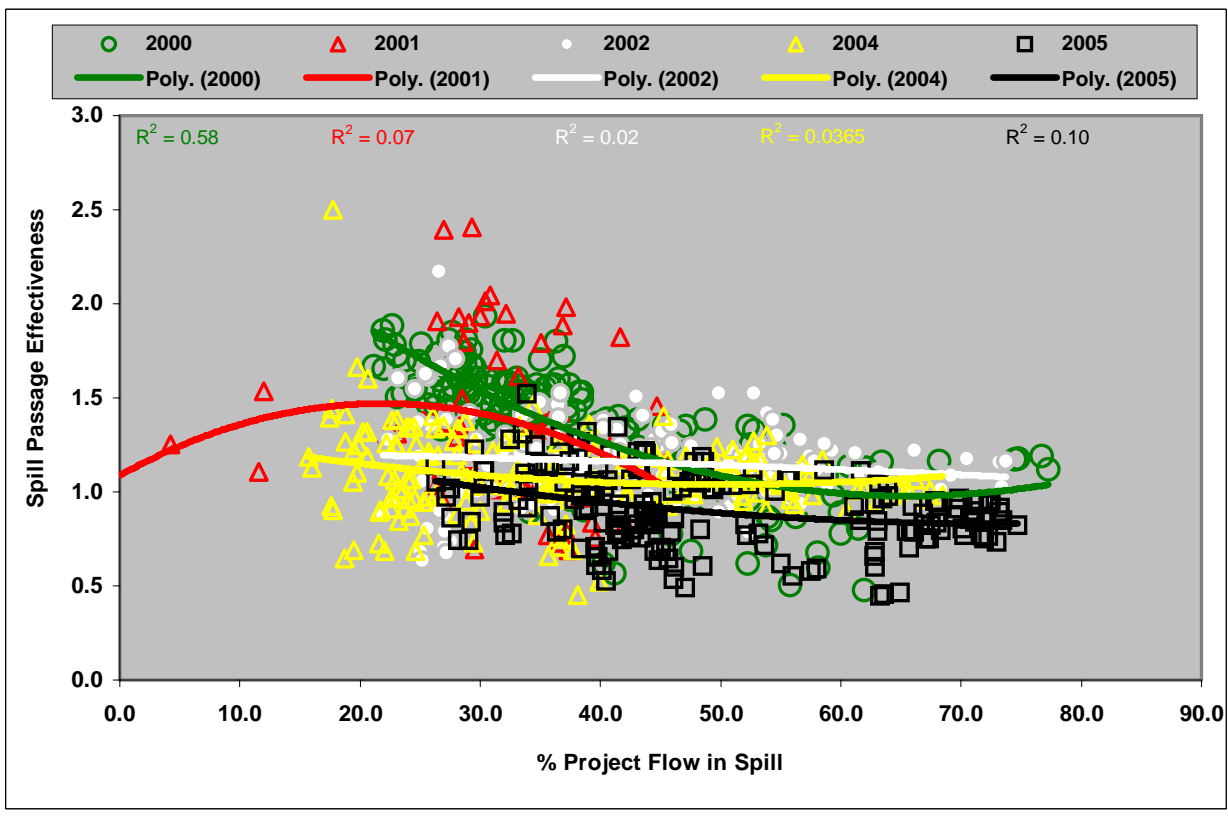

Figure 3.17. Regression of Day and Night Estimates of Spill-Passage Effectiveness on Percent Spill by Year 
Percent of B1 flow into the B1 sluiceway explained $67 \%$ of the variation in B1 sluiceway effectiveness, mostly because the effectiveness of the B1 sluiceway was very high at low flow percentages and then declined exponentially, something that was not observed for the spillway (Figure 3.18). Differences between predicted estimates of effectiveness for the B1 sluiceway and the spillway based upon percent flow through the respective routes were much larger at low percent flow (20:1 at $1 \%$ flow) than they were at high percent flow (2:1 at $80 \%$ flow).

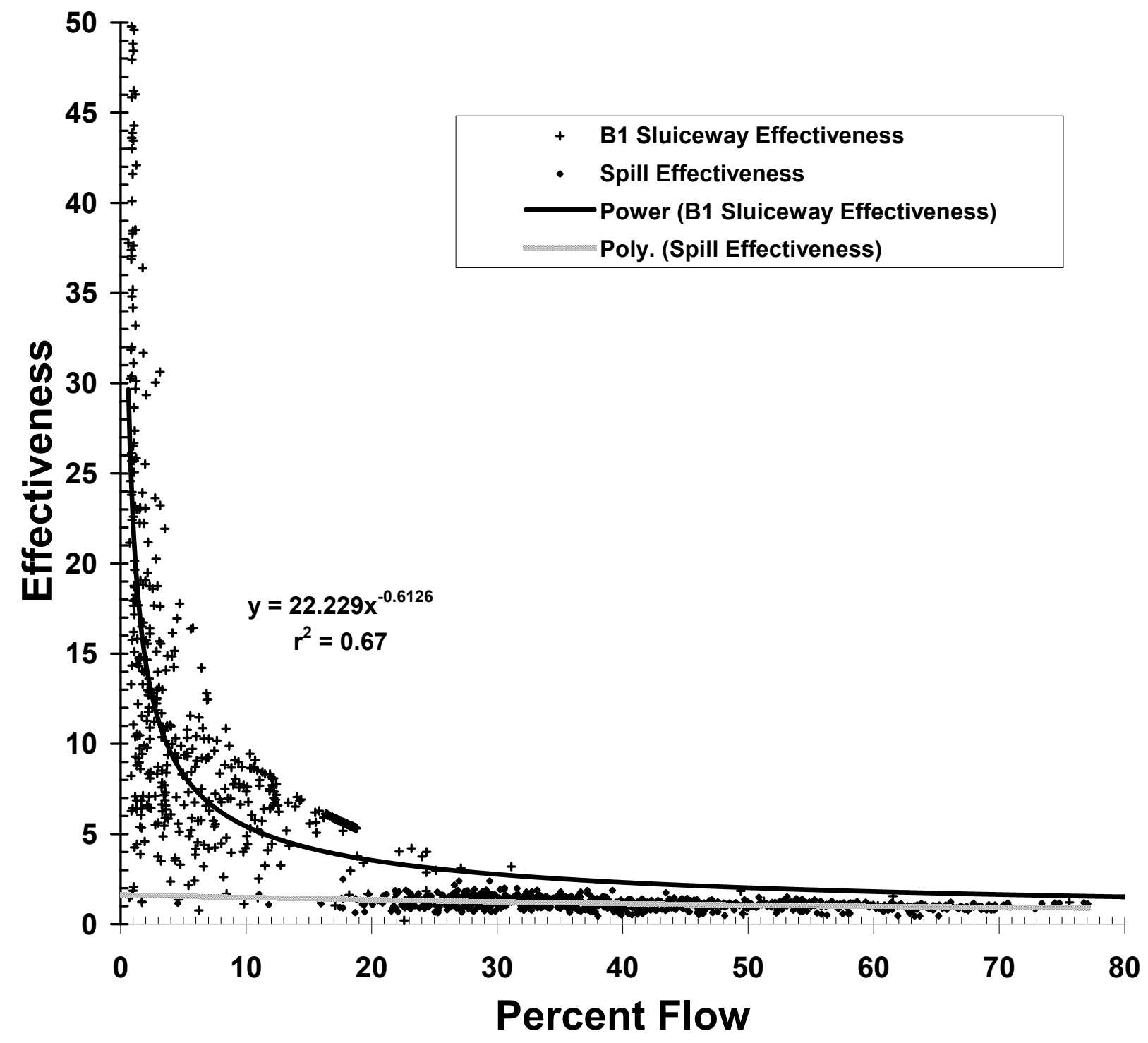

Figure 3.18. Regression of Day and Night Estimates of B1 Sluiceway Effectiveness on Percent of B1 Flow and Spill-Passage Effectiveness on Percent of Project Flow Spilled

A similar trend of high effectiveness at low flow percentage was observed for the $\mathrm{B} 2 \mathrm{CC}$, where predicted effectiveness was about 8:1 at 4\% of B2 flow through the $\mathrm{B} 2 \mathrm{CC}$ and about 4:1 at 15\% flow (Figure 3.19). The range of percent flow for the $\mathrm{B} 2 \mathrm{CC}(4 \%-15 \%$ of $\mathrm{B} 2 \mathrm{flow})$ was much narrower than it 
was for the B1 sluiceway (1\%-100\% of B1 flow) and the spillway (4\%-80\% of project flow), and this probably explains the low R2 of $14 \%$ for the $\mathrm{B} 2 \mathrm{CC}$ data. At $4 \%$ flow, the normal operating percentage for the B2CC, effectiveness was about 5.33 times higher than spill effectiveness (Figure 3.19).

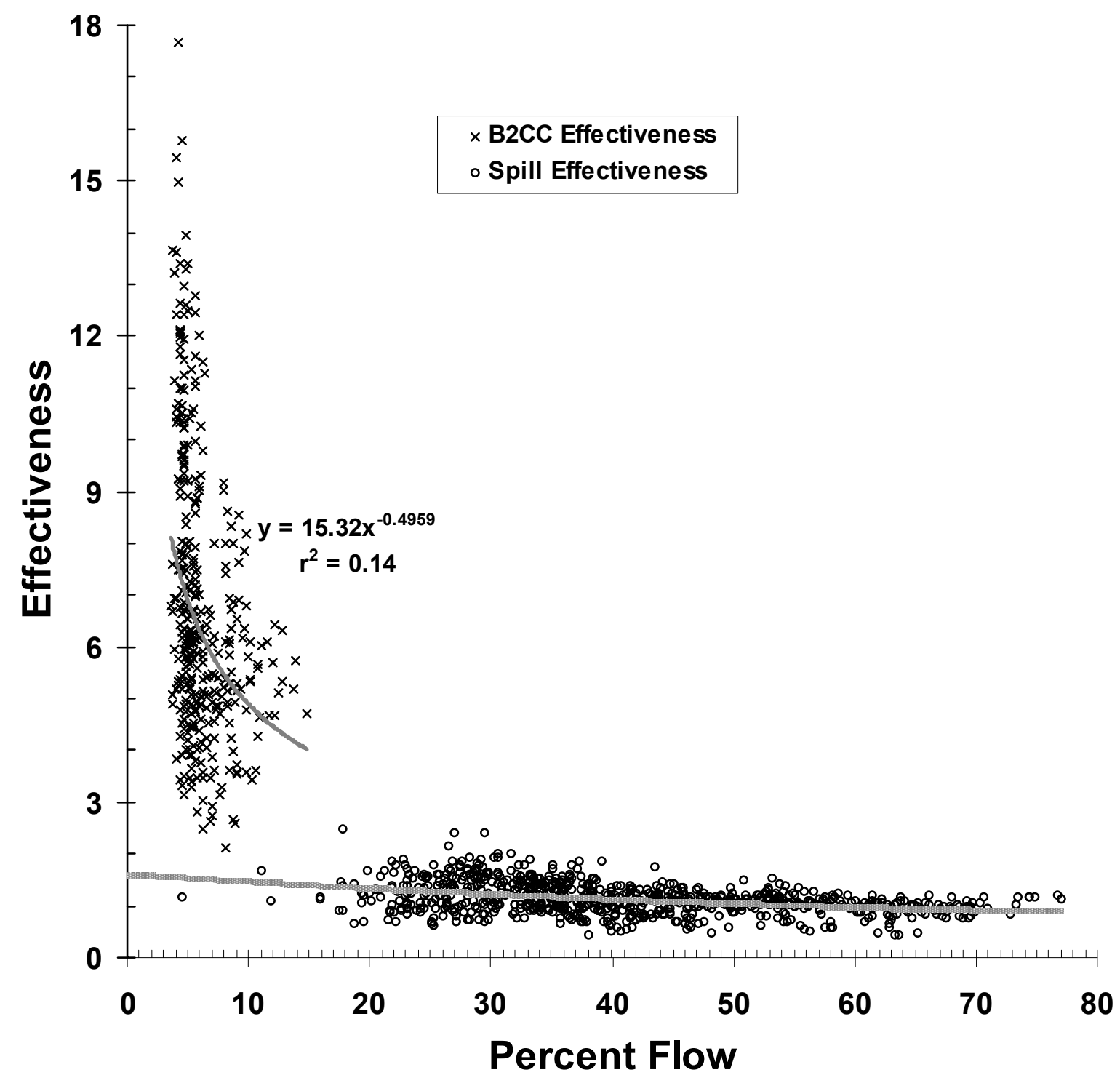

Figure 3.19. Regression of Day and Night Estimates of B2CC Effectiveness on Percent of B2 Flow and Spill-Passage Effectiveness on Percent of Project Flow Spilled

We regressed all day and night estimates of percent of project fish passage through B1 and B2 turbines on the percent of project flow through those turbines, and the resulting curves were similar to each other (Figure 3.20 and 3.21). The range in percent flow was higher for B2 turbines (0\%-100\%) than it was for B1 turbines ( $0 \%-80 \%)$. The highest points for B2 turbines were from data acquired in 2001, and the lowest points were from 2000. In contrast, the highest points for B1 turbines were acquired in 2000 , and the lowest points were contributed by all years except 2000 . 


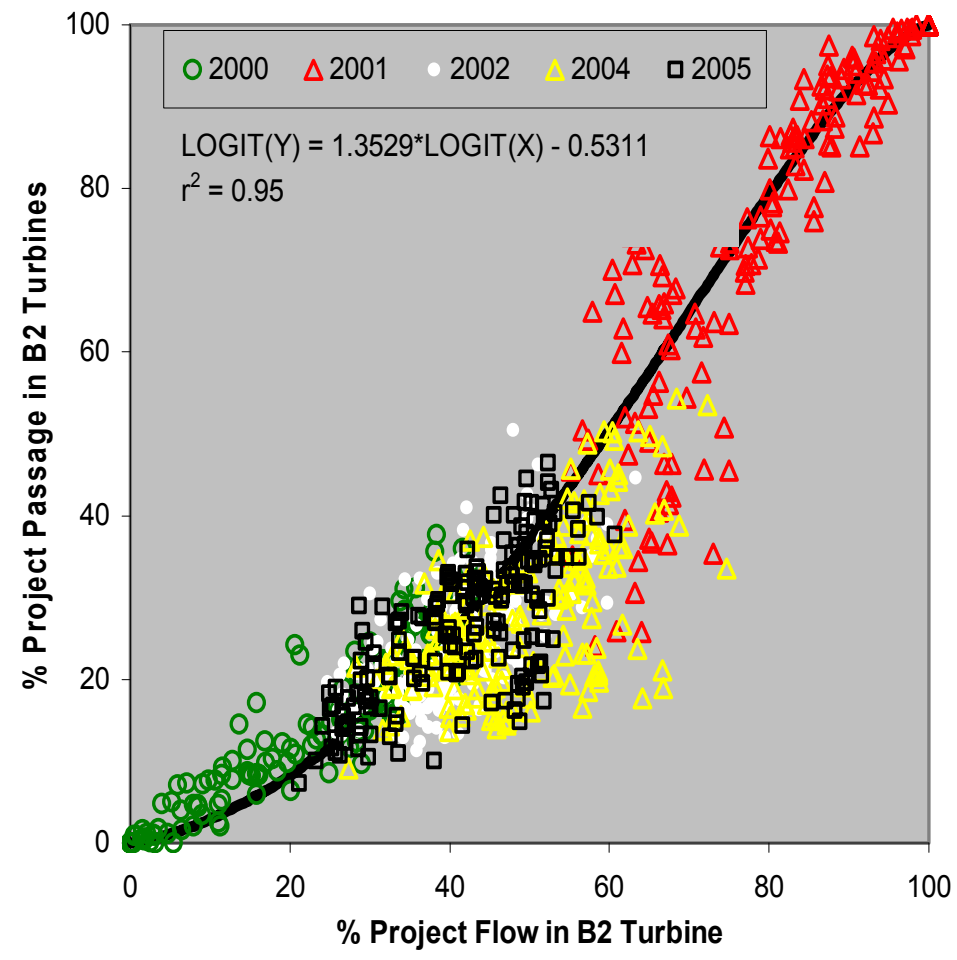

Figure 3.20. Logit Regression of Day and Night Estimates of B2 Turbine Passage Efficiency on Percent of Project Flow through B2 Turbines

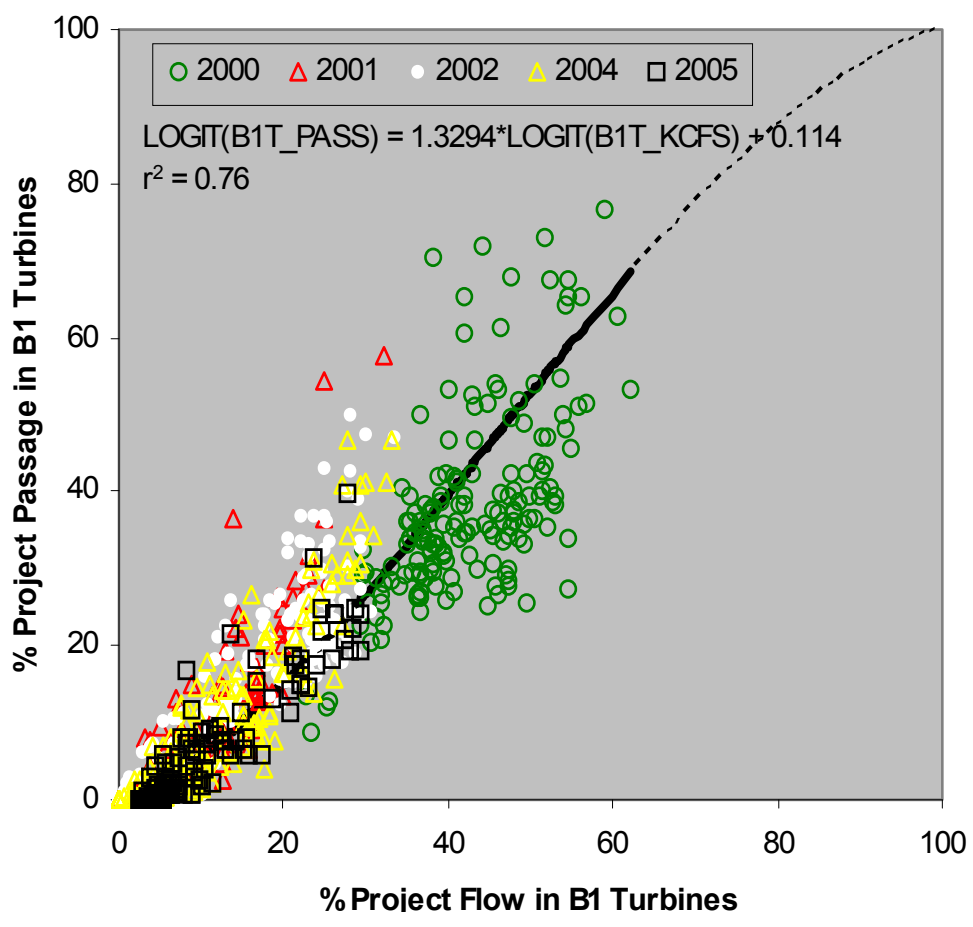

Figure 3.21. Logit Regression of Day and Night Estimates of B1 Turbine Passage Efficiency on Percent of Project Flow through B1 Turbines. The dashed portion of the fitted line is an extrapolation to a known endpoint. 
Logit transformed day and nighttime estimates of percent spill explained $50 \%$ of the variation in spill efficiency over all five years studied (Figure 3.22). We excluded 112 points where there was zero percent spill and zero percent passage from the 2001 dataset because they overly influenced the fit of the regression line when included (Figure 3.23).

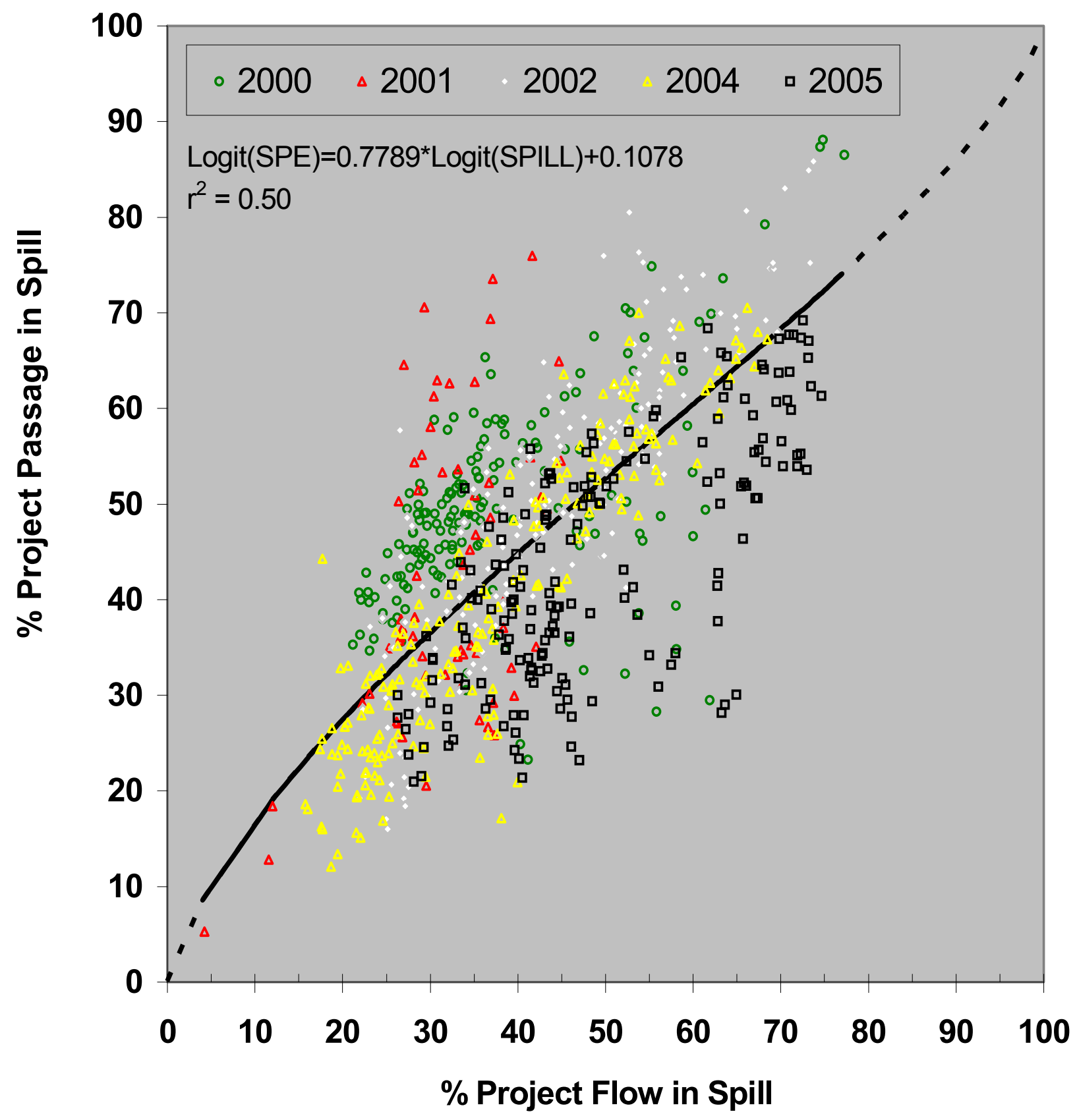

Figure 3.22. Regression of Day and Night Estimates of Spillway Efficiency on Percent Spill 


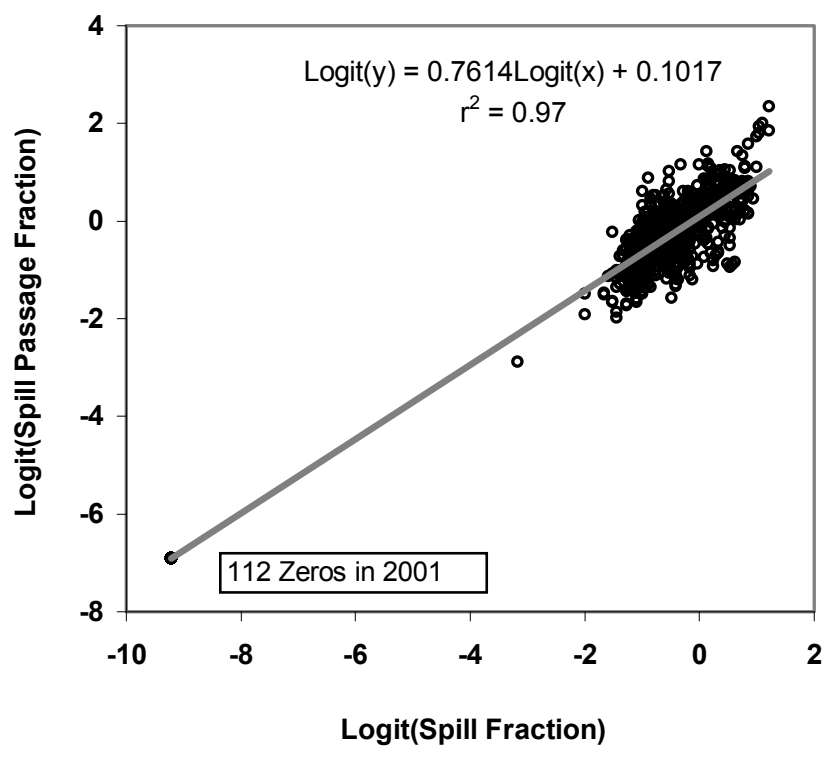

Figure 3.23. Logit Regression of Day and Night Estimates of Spill Passage Efficiency on Percent Spill including 112 0,0 Points Observed in 2001

Responses of percent of adjacent powerhouse passage through surface-passage routes like the B1 sluiceway (Figure 3.24) or the B2CC (Figure 3.25) increased very rapidly at low levels of percent flow. On average, the percent of B1 passage through the B1sluiceway was about $40 \%$ at $1 \%$ of B1 flow (the minimum flow), $73 \%$ at $5 \%$ flow, $83 \%$ at $10 \%$ flow, and $88 \%$ at $15 \%$ flow (Figure 3.24 ). The percent of B2 passage through the $\mathrm{B} 2 \mathrm{CC}$ was $30 \%$ at $4 \%$ of $\mathrm{B} 2$ flow (the minimum flow), $36 \%$ at $5 \%$ flow, $52 \%$ at $10 \%$ flow, and $62 \%$ at $15 \%$ flow (Figure 3.25 ). The remaining percentages of B1 or B2 passage at any percent flow represent what would pass through adjacent turbines.

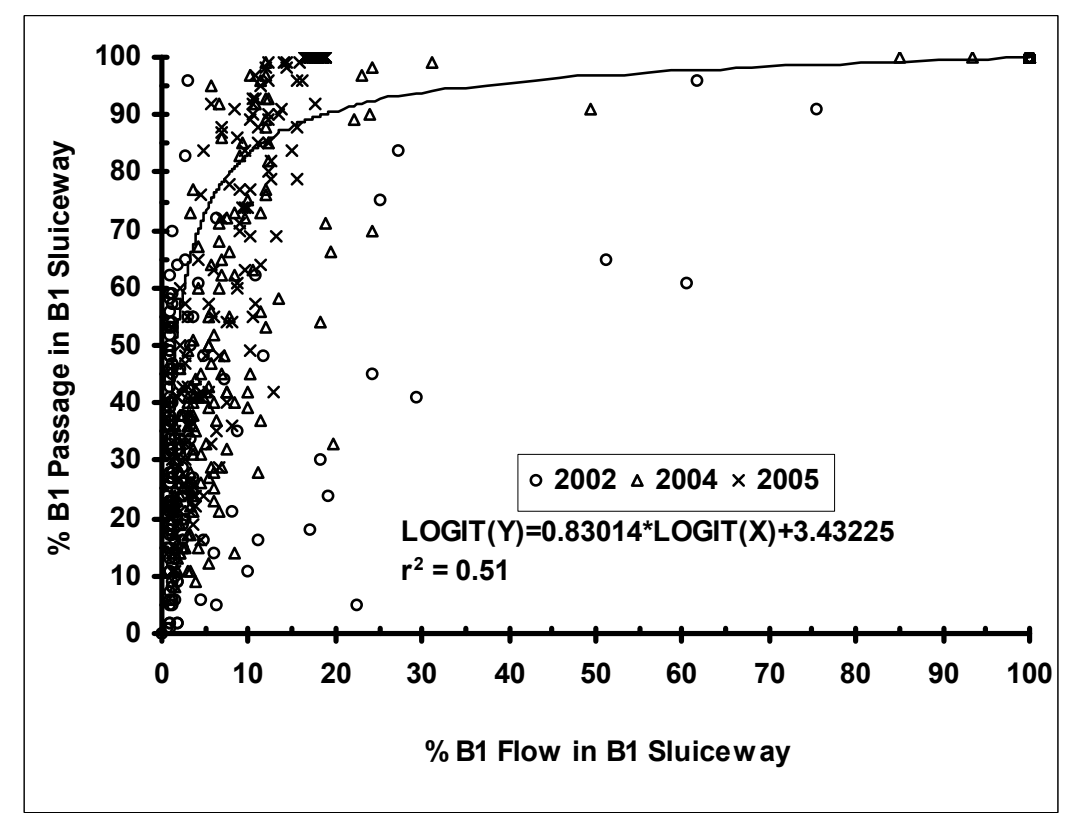

Figure 3.24. Logit Regression of Day and Night Estimates of B1 Sluiceway Passage Efficiency on Percent of B1 Flow Passing the B1 Sluiceway 


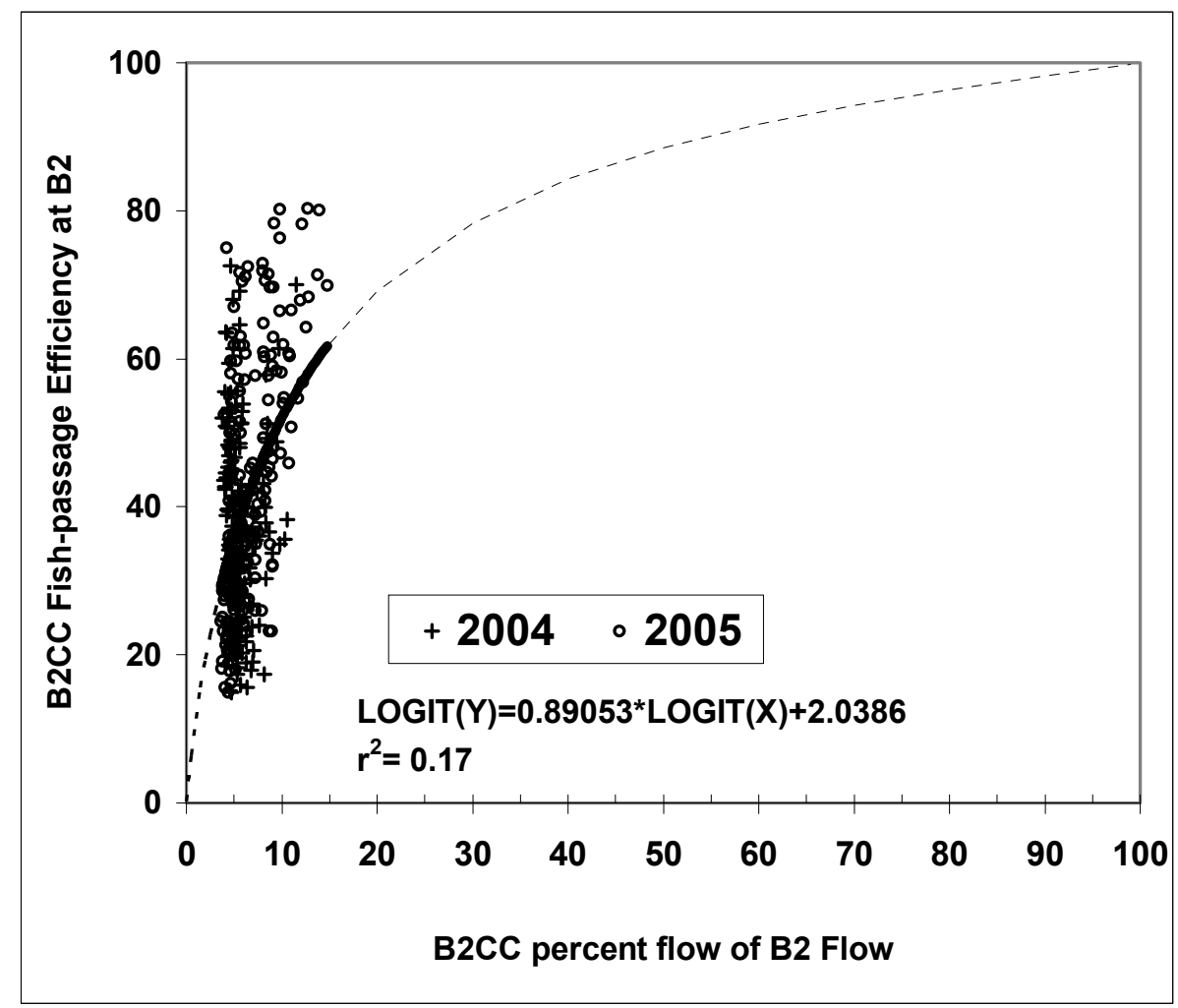

Figure 3.25. Logit Regression of Day and Night Estimates of the B2CC Passage Efficiency on Percent of B2 Flow Passing into the B2CC with Full Extrapolation to Known Endpoints Shown as a Dashed Line

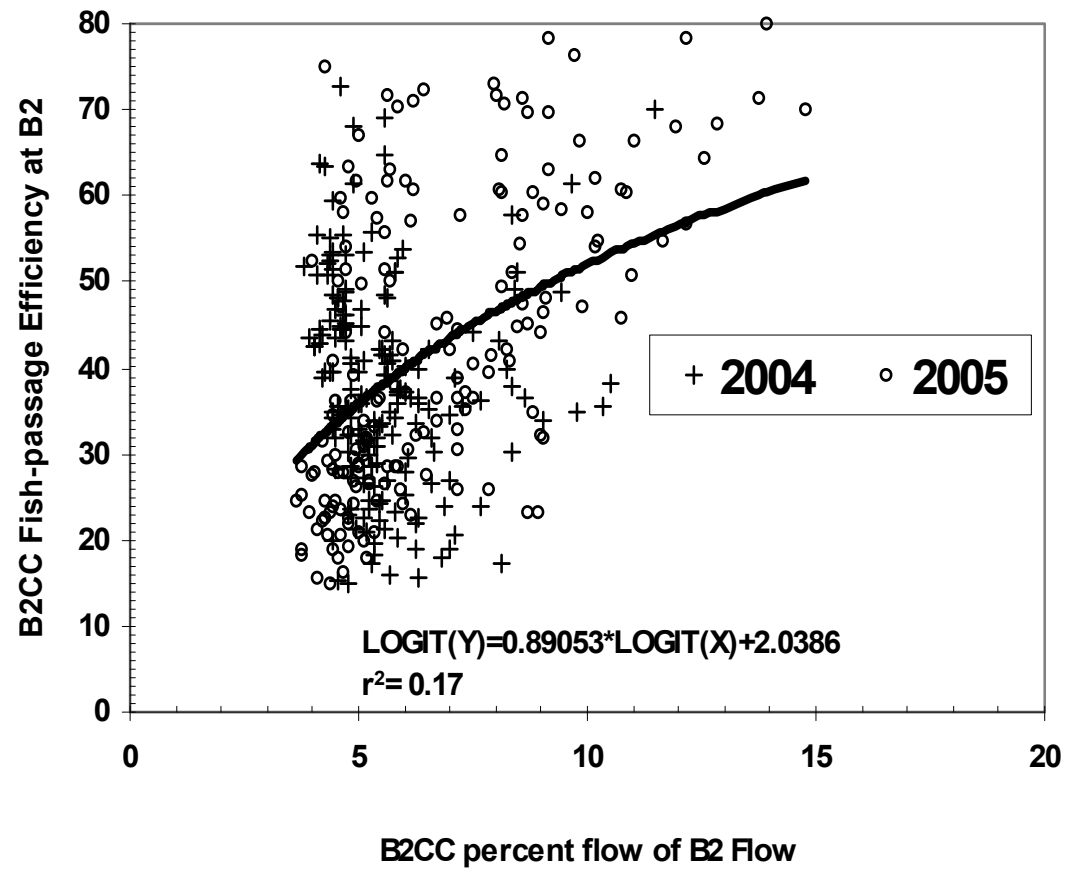

Figure 3.26. Logit Regression of Day and Night Estimates of the B2CC Passage Efficiency on Percent of B2 Flow Passing into the B2CC with No Extrapolation 
Percent of project flow through surface flow outlets (SFO) explained $44 \%$ of the variation in fish passage there (Figure 3.27). At just $6 \%$ of project flow, predicted passage was over $30 \%$ of project passage, and this was at least three times higher than percent passage predicted for spill (Figure 3.28).

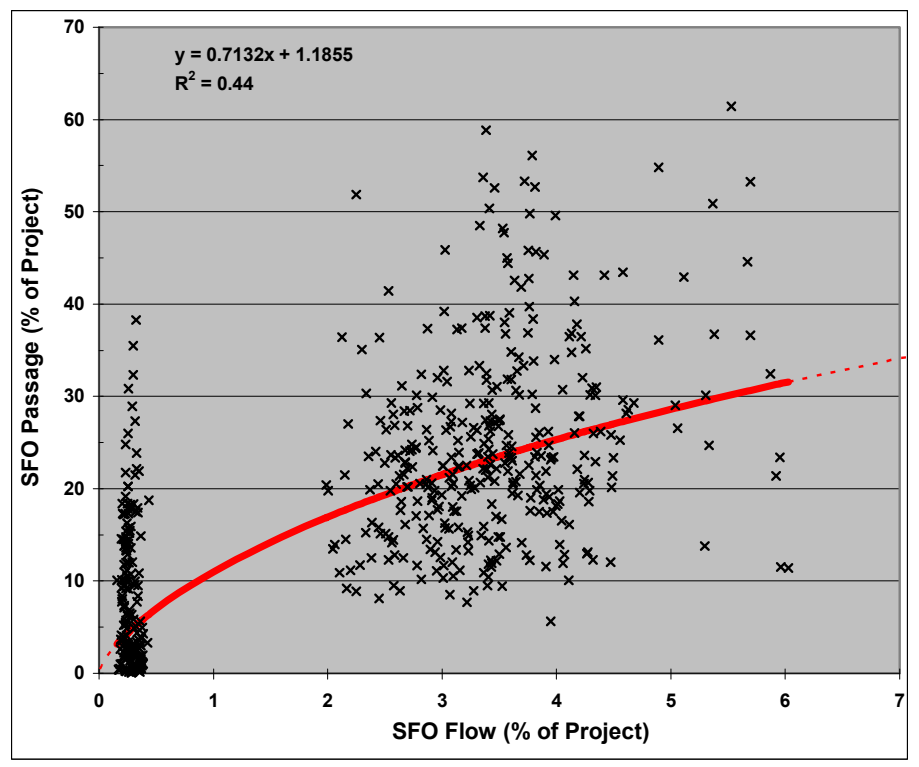

Figure 3.27. Logit Regression of Day and Night Estimates of Percent of Project Fish Passage through Surface Flow Outlets (SFO = B1 Sluiceway and B2CC Combined) on Percent of Project Flow through the Same Routes. The dashed portion of the line is an extrapolation toward a known endpoint $(100,100)$.

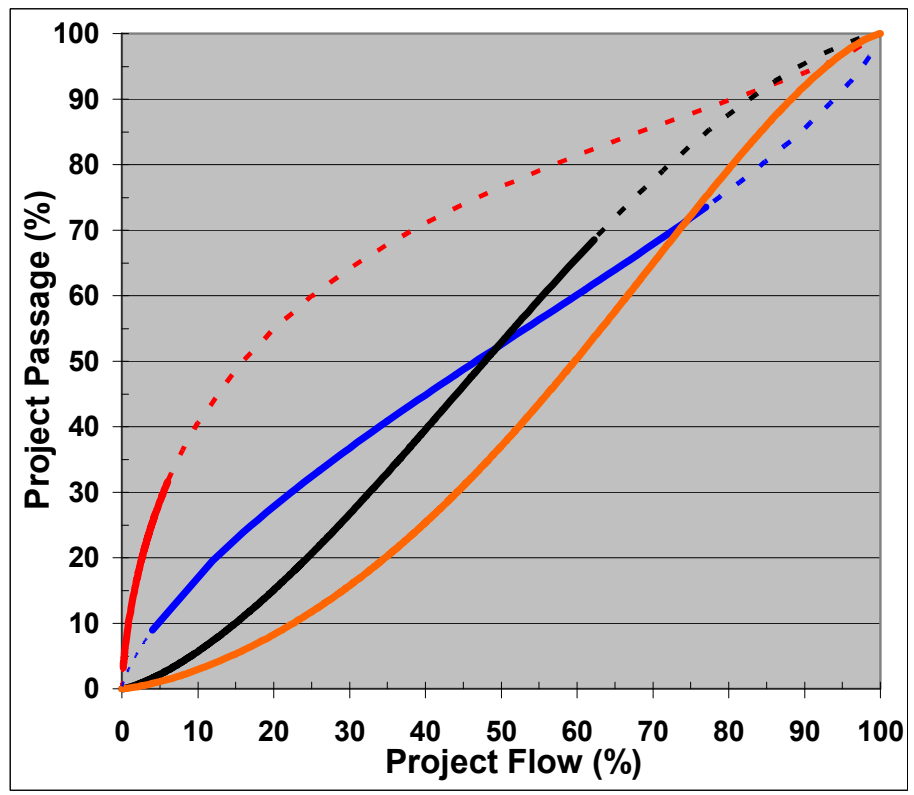

Figure 3.28. Logit Regression Lines Summarizing Percent of Project Passage by Route as a Function of Percent of Project Flow through the Same Route. The red line is the predicted response for surface flow outlets, blue is for spill, black for B1 turbines, and gold for B2 turbines. Lightly dashed portions of lines are extrapolations to known endpoints. 
Day and night estimates of percent spill from the five years of study explained $52 \%$ of the variation in fish passage efficiency (Figure 3.29). Fish passage efficiency, which is the percent of total passage through non-turbine routes, increased from an average of 50\% when there was no spill to about $90 \%$ when percent spill was about $78 \%$ of total project flow. Each $1 \%$ increase in spill buys a $0.55 \%$ increase in non-turbine passage.

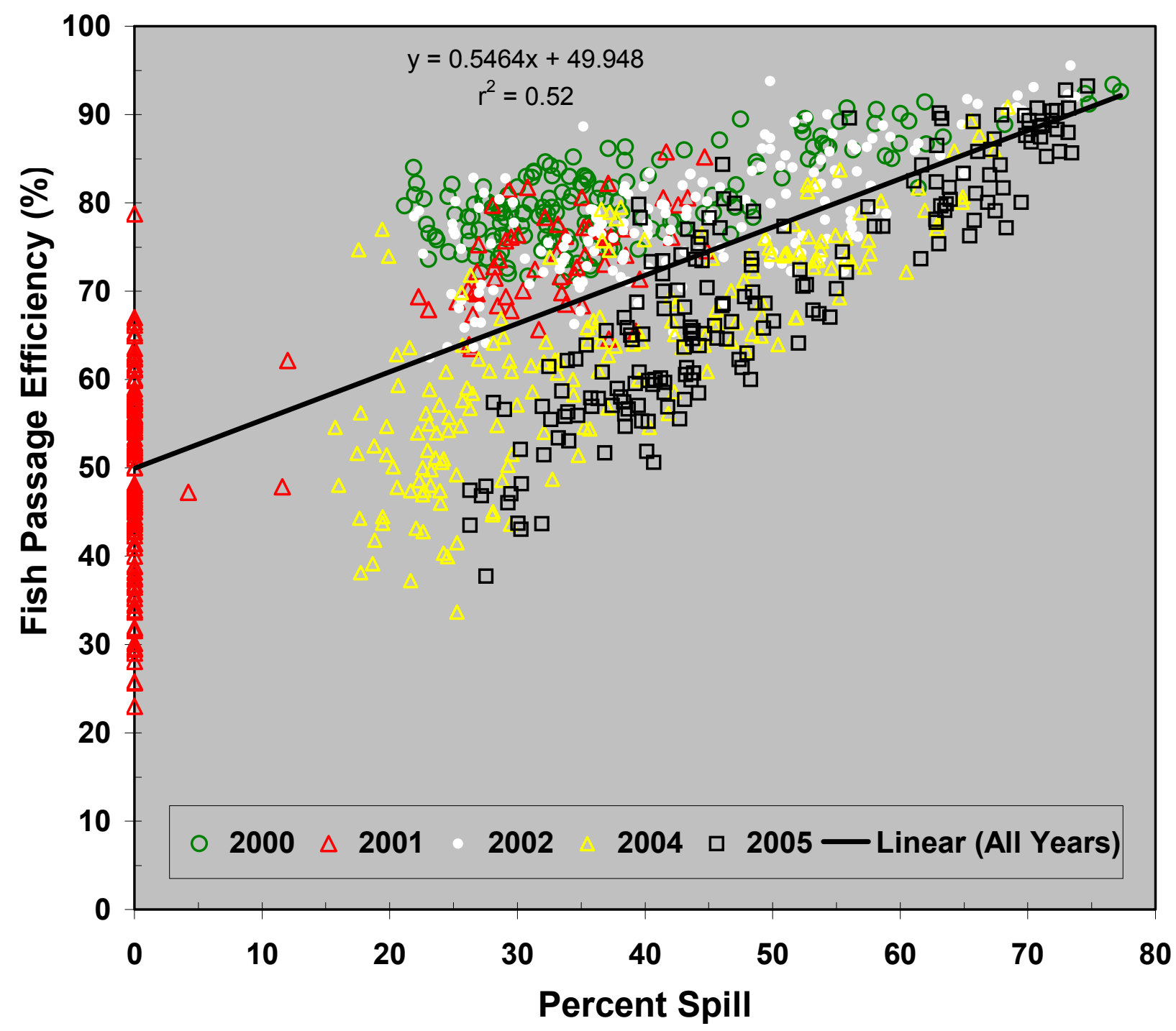

Figure 3.29. Regression of Fish-Passage Efficiency on Percent Spill for Bonneville Dam. Points are from five different years and were estimated for day and night periods.

Regression lines varied a lot among years, with percent spill explaining from $47 \%$ to $79 \%$ of the variation in fish-passage efficiency (Figure 3.30). Slopes in 2000 and $2002(0.29$ and 0.38$)$ were less than slopes in 2001, 2004, and 2005. Intercepts also varied widely, from lows in 2004 (37\%) and 2005 (28\%) to highs in $2000(69 \%)$ and $2002(62 \%)$. However, data acquired during days of low spill and no spill in 
2001 were most important for defining the intercept, which was about $49 \%$ when there was no spill. There were no data collected when spill was $<15 \%$ in other years.

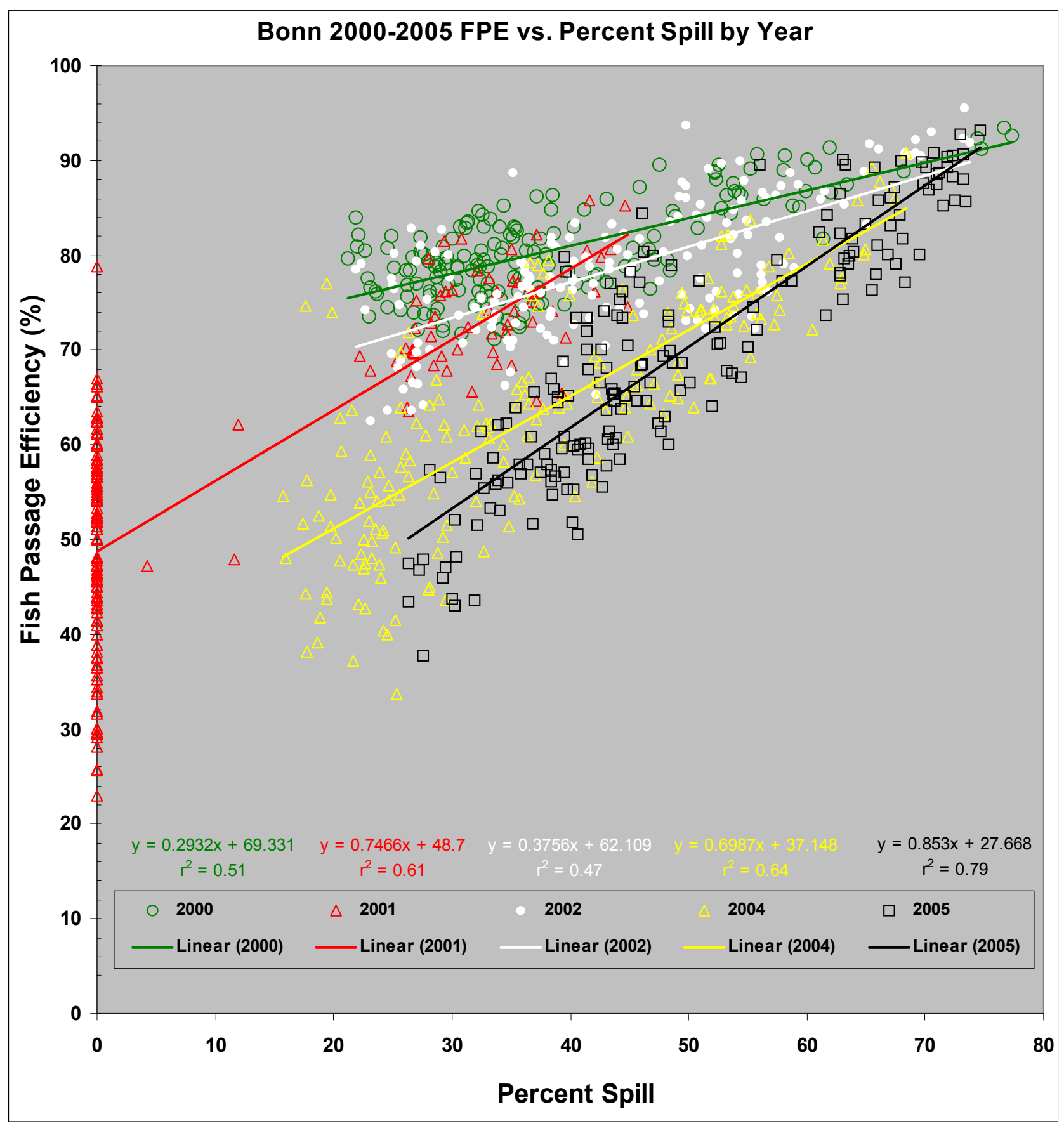

Figure 3.30. Regression of Fish-Passage Efficiency on Percent Spill by Year of Study at Bonneville Dam. Points are from five different years and were estimated for day and night periods. 
Trends in spill efficiency also varied among years with slopes ranging from 0.88 to 1.31 (mean $=$ 1.13). In three of the five years $(2001,2002$, and 2004), the fit of regression lines was significantly better $\left(r^{2}=0.76-0.87\right.$; Figure 3.31) than the fit of a regression line fit to all data $\left(r^{2}=0.50\right.$; Figure 3.22); in 2005 the fit was comparable $\left(2005 r^{2}=0.47\right)$ to that of the overall regression; and in 2000 the $r^{2}$ was just $31 \%$.

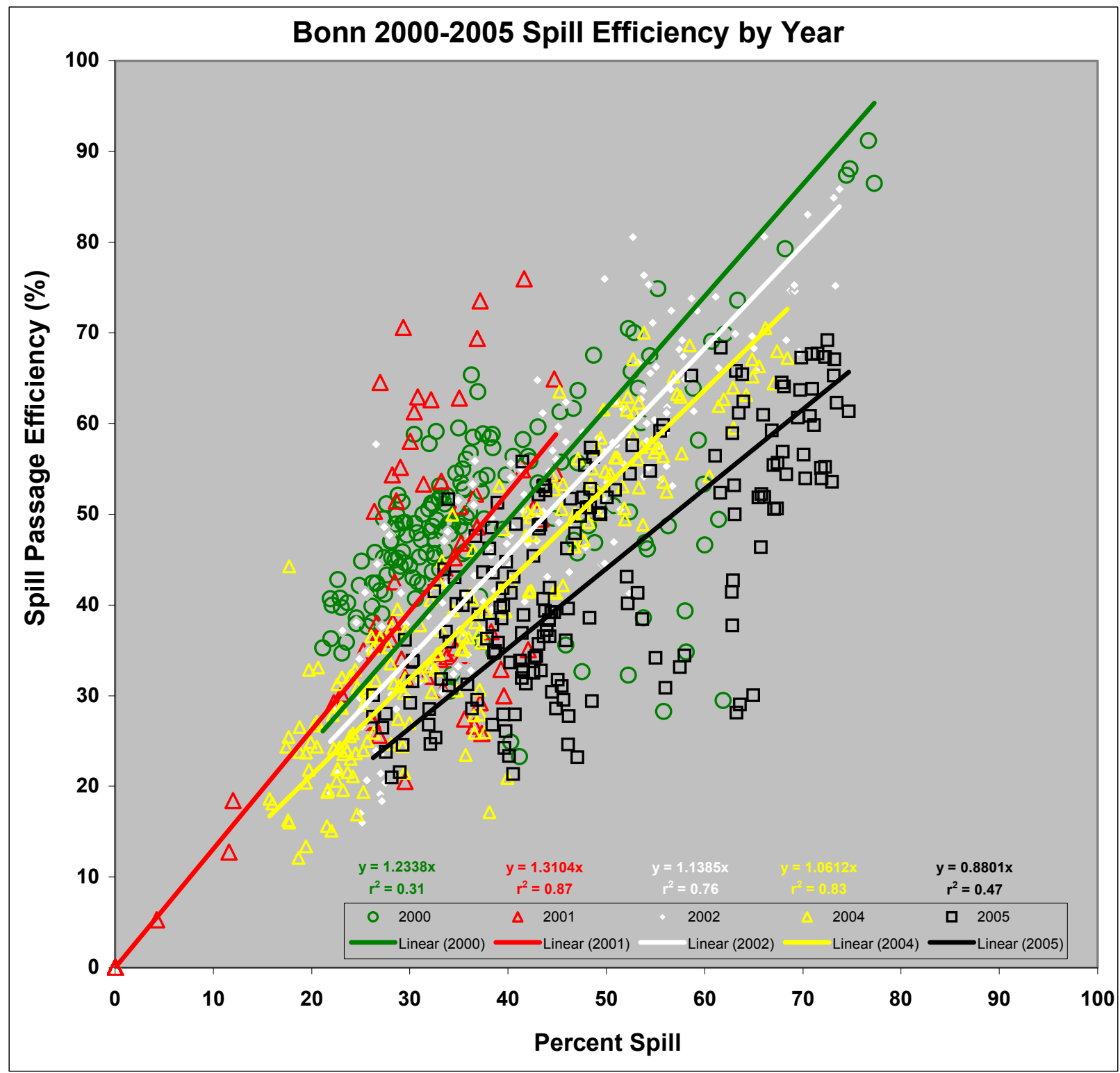

Figure 3.31. Regression of Spill Efficiency on Percent Spill by Year of Study at Bonneville Dam. Points are from five different years and were estimated for the day and night period of each day sampled. 
Re-Analysis of Hydroacoustic Fish-Passage Data from Bonneville Dam after Spill-Discharge Corrections 


\subsection{Discussion}

\subsection{Environmental Conditions}

The five years studied included one year with percent spill and discharge that were among the lowest ever recorded (2001), but they did not include a year of above-average discharge or percent spill. The five years were on the end of a 40-year trend of decline in average project and spill discharge and percent spill, so they may not provide inference for years of above-average discharge and spill.

\subsection{Hydroacoustic Detectability}

The motivation for efforts to improve detectability modeling is the desire to provide hydroacoustic estimates that are quantitative as well as relative indices to fish passage. Ratio estimators such as fish guidance efficiency only require that the hydroacoustic beams sampling guided and unguided fish have equal detectability so that the ratios of counts, not necessarily the counts themselves, are accurate. Combining counts from different locations such as powerhouses and a spillway also requires equal detectability so that counts from different locations are comparable, although the counts themselves may not be accurate. Nevertheless, accurate counts estimated by proper expansion of detected fish have the potential to provide estimates with inherent quantitative value as well as providing acceptable relative estimates.

Our adjustment of spill-passage estimates in years before 2005 to compensate for declining detectability with increasing spill discharge through individual bays made a very slight and inconsequential improvement to the fit of regressions of fish-passage and spill-passage efficiency on percent spill. We thought that the detectability adjustment might make linear regression models fit better than curvilinear models, but this was not the case for data acquired from 2000 through 2004 (Figure 3.12). However, uncorrected data were equally well fit by linear and quadratic regression equations, as were corrected data. Nevertheless, modeling effects of spill-bay discharge on detectability and adjusting passage estimates probably was the correct approach for providing spillway passage estimates that were as quantitative as possible. As ratio estimators, spill-passage and fish-passage efficiency are buffered from changes in spill-passage estimates because both the numerator and denominator increase with increases in spill passage.

\subsection{Major Fish-Passage Metrics}

Based on the results of re-analysis, the effectiveness measures in Ploskey et al. (2002a, b; 2003; and 2004) should not be used and should be superseded with the new estimates in Tables 3.3 and 3.4. Spill effectiveness increased $10 \%-21 \%$ in spring and $17 \%-23 \%$ in summer, and the amount of change explained by spill-discharge adjustments alone was $61 \%$ in $2000,51 \%$ in $2001,53 \%$ in 2002 , and $76 \%$ in 2004. The remainder was explained by increased spill efficiency resulting from increased fish passage through the spillway as a consequence of our detectability adjustments for the spillway. In 2002 and 2004, adjustments that reduced spill discharge and increased spill passage reduced project-wide surfacepassage effectiveness by $10 \%-11 \%$ by reducing the numerator and increasing the denominator of that ratio estimator.

The original reports and all associated results, discussion, and conclusions for non-effectiveness measures remain valid. Project-wide efficiency metrics (fish-passage, spill-passage, sluiceway passage) 
changed less than 3\%. Likewise, information on temporal and spatial distributions of passage and FGE at turbines were unaffected by the re-analysis.

\subsection{Relations between Passage Metrics and Percent Flow by Route}

\subsubsection{Spill Effectiveness}

There was only a weak negative relationship between spill effectiveness and percent spill at Bonneville Dam (Figure 3.16 and 3.17), and this probably results from the isolation of the spillway from powerhouse routes. Spill effectiveness at Columbia River dams typically is higher than 1.17:1 or 1.29:1, the average at Bonneville for the five years of hydroacoustic study. For example, spill effectiveness at Lower Granite Dam in spring 2002 ranged from 1.8 to 3.3 and averaged 2.2 (Anglea et al. 2003). Overall spill-passage effectiveness at John Day Dam was 2.7 in spring and 2.3 in summer of 2002 (Moursund et al. 2003). In both examples, project operations and the proximity of the project powerhouse to the spillway contributed to the spillway being able to take fish away from the powerhouse and concentrate them in spillway passage. For effectiveness to be much above 1:1 at Bonneville Dam, fish would have to preferentially select the spillway over either powerhouse. Unfortunately, islands funnel fish to the three forebays before fish are exposed to forebay conditions that might allow them to make a selection. Radio Telemetry estimates of spill effectiveness also were near 1:1 for Bonneville Dam (Table 4.1), and those results also support the hypothesis that spillway isolation from both Powerhouses prevents the spillway from attracting fish from either powerhouse forebay.

Table 4.1. Radio Telemetry Estimates of Spill Effectiveness at Bonneville Dam during Study Years (Adams et al. 2006)

\begin{tabular}{|l|c|c|c|c|c|c|}
\hline \multicolumn{1}{|c|}{ Season and Species/Run } & $\mathbf{2 0 0 0}$ & $\mathbf{2 0 0 1}$ & $\mathbf{2 0 0 2}$ & $\mathbf{2 0 0 4}$ & $\mathbf{2 0 0 5}$ & Mean \\
\hline Yearling Chinook salmon & 1.3 & 0.7 & 0.9 & 0.9 & 0.9 & 1.0 \\
\hline Steelhead & 1.0 & & 1.2 & 0.7 & 1.0 & 1.0 \\
\hline Subyearling Chinook salmon & 1.2 & 0.8 & 1.3 & 0.9 & 1.0 & 1.0 \\
\hline
\end{tabular}

Radio telemetry data also indicate that few fish detected in one of the three forebays move to a different forebay before passing the project. Lateral smolt distribution on approach to Bonneville Dam influenced whether the ultimate passage route was B1, the spillway, or B2 (e.g., Hensleigh et al. 1999). In 1996, 1997, and 1998, investigators coupled data describing the location of radio-tagged smolts upstream of Boat Rock with data identifying the location where these tagged fish passed the dam (Holmberg et al. 1996; Hensleigh et al. 1999; Hansel et al. 1999). Fish distributed to the south side of the channel were likely to pass the dam at B1 or the spillway. Fish distributed to the north side of the channel were likely to pass the dam at B2 or the spillway.

\subsubsection{Surface Passage Effectiveness}

Very high passage effectiveness at surface passage routes probably results from juvenile salmonids preferentially selecting those routes over adjacent turbines. Passage effectiveness of the B1 sluiceway and B2CC were much higher at low percent flow than was passage effectiveness at the spillway 
(Figures 3.18 and 3.19). Surface-passage effectiveness was higher than spill-passage effectiveness throughout the observed range in percent flow at the sluiceway, particularly when flow was $<15 \%$.

\subsubsection{Relative Efficiency as a Function of Percent Flow}

Logit regressions explained 95\% of the variation in percent fish passage for B2 turbines, 75\% for B1 turbines, and just $50 \%$ for the spillway, but trends in fitted curves for these routes were similar (compare Figures 3.20, 3.21, and 3.22). The fit of the spillway regression was degraded by the addition of 2005 data, which tended to have lower spillway efficiency estimates than those recorded in prior years compare the right plot in Figure $3.12\left(r^{2}=0.82\right)$ with Figure $3.22\left(r^{2}=0.50\right)$. The spillway regression could be improved by increasing the number of observations with low (4\%-20\%) and high (80\%-100\%) percent spill.

Responses of percent of adjacent powerhouse passage through surface flow outlets like the B1 sluiceway (Figure 3.24) or the B2CC (Figure 3.25) increased very rapidly at low levels of percent flow, and this clearly indicates that juvenile salmonids preferentially select surface outlets over adjacent turbines. The high effectiveness of surface outlets and proximity to turbines should make them the first choice of managers for optimizing flow to increase non-turbine passage rather than spill. In contrast to efficiency plots for the spillway and powerhouses, plots for the B1 sluiceway and B2CC showed very rapid increases in efficiency with very modest increases in percent flow relative to the adjacent powerhouse. At B1, most of the benefit from increasing percent flow into the sluiceway (83\% efficiency) was realized by providing $10 \%$ of B1 flow. The effect was not as dramatic at the B2CC (62\% efficiency with 15\% of B2 flow) as it was for the B1 sluiceway. The percent of total project passage by surface routes also was three times higher than that of the spillway and 10 times higher than that of turbines at low percent flow (Figure 3.28).

The addition of the B2CC in 2004 and 2005 nearly compensated Project FPE for the non-deployment of B1 screens, and this was without any effort to optimize surface flow outlet performance. The average FPE for the non-drought years of 2000 and 2002 when screens were deployed in B1 turbines was 79.5\% in spring and $78 \%$ in summer, and this was only $6 \%$ and $2 \%$ higher than respective spring and summer average estimates for 2004 and 2005 when no B1 screens were deployed. If the B1 sluiceway had 10\% of B1 flow instead of $<1 \%$, our results suggest that the B1 sluiceway alone could pass $>80 \%$ of arriving smolts and more than compensate for not deploying B1 screens. From 2000 through 2002, B1 screens in turbines guided 37\%-67\% of fish in spring and 39\%-45\% in summer. The effectiveness of the B1 sluiceway and B2CC was highest at the lowest flow (Figures 3.18 and 3.19), and this suggests that having many low-flow outlets to supply the channel capacity would be more effective than having a few larger outlets.

\subsubsection{Recommendations}

Spill has been and certainly can be used to increase non-turbine passage at Bonneville Dam, but it is not an efficient use of water because the project has two islands that isolate spillway flow from powerhouse flow before fish can select a preferred route. Consequently, spill efficiency will always be directly proportional to percent spill, with effectiveness ranging from about 0.7 to 1.3 . We recommend a more efficient approach to increase non-turbine passage, i.e., optimizing percent flow to the B1-sluiceway and B2CC because these routes can reduce turbine passage by out competing adjacent turbines for fish. The spillway cannot compete directly with turbines for fish. We are not saying that spill should be eliminated, but it may be possible to reduce reliance on spill to pass juvenile salmonids by fully realizing all potential benefits of surface passage through structural and operational changes. Turbines are about as 
efficient as the spillway at any percent of project flow, but surface routes are much more efficient than turbines at low percent flow. The average percent of B1 flow through the B1 sluiceway (1\%-2\%) is well below an optimum amount of $10 \%$, but hopefully planned improvements in that system will greatly improve its performance in the future.

Given the very high effectiveness of surface routes at the lowest flow, we recommend testing the use of many low-flow surface outlets at B1 versus the use of a few outlets passing equivalent flow. Without structural modification, attaining $10 \% \mathrm{~B} 1$ flow to the sluiceway requires shutting down turbines, which is how $50 \%$ to $100 \%$ of $\mathrm{B} 1$ flow to the sluiceway was possible at times. Given the B2 powerhouse priority, it is difficult to imagine increasing percent of B2 flow to the B2CC much above the median $4 \%$ observed in 2004 and 2005. The installation and testing of a smolt guidance device in the B2 forebay may be a viable alternative to increasing percent flow from $4 \%$ to $15 \%$. Previous observations of $10 \%-15 \%$ of B2 flow to the B2CC always occurred at night when turbines were shut down to accommodate increased spill (to the gas cap) at night. Of course, a thorough understanding of route-specific survival is critical for choosing the best route for fish. 


\subsection{References}

Adams, N.S., R.E. Reagan, S.D. Evans, M.J. Farley, L. Wright, and D.W. Rondorf. 2006. Movement, Distribution, and Passage Behavior of Radio-Tagged Juvenile Chinook Salmon and Steelhead at Bonneville Dam, 2005. Draft Report of Research by the U.S. Geological Survey to the U.S. Army Corps of Engineers, Portland District, Contract W66QKZ50458498, Portland, Oregon.

Anglea, S.M., K.D. Ham, G.E. Johnson, M.A. Simmons, C.S. Simmons, E. Kudera, and J. Skalski. 2003. Hydroacoustic Evaluation of the Removable Spillway Weir at Lower Granite Dam in 2002. PNNL3219, final report prepared by Pacific Northwest National Laboratory, Richland, Washington, for the U.S. Army Corps of Engineers District, Portland, Oregon.

Hansel, H.C., R.S. Shively, J.E. Hensleigh, B.D. Liedtke, R.E. Wardell, R.H. Wertheimer, and T.P. Poe. 1999. Movement, Distribution, and Behavior of Radio-Tagged Juvenile Chinook Salmon and Steelhead in the Forebay of Bonneville Dam, 1998. Annual Report by the U.S. Geological Survey, Columbia River Research Laboratory, Cook, Washington for the U.S. Army Engineer District, Portland, Oregon.

Hensleigh, J.E., R.S. Shively, H.C. Hansel, J.M. Hardiman, G.S. Holmberg, B.D. Liedtke, T.L. Martinelli, R.E. Wardell, R.H. Wertheimer, and T.P. Poe. 1999. Movement, Distribution, and Behavior of Radio-Tagged Juvenile Chinook Salmon and Steelhead in John Day, The Dalles, and Bonneville Dam Forebays, 1997. Annual Report by the U.S. Geological Survey, Columbia River Research Laboratory, Cook, Washington for the U.S. Army Engineer District, Portland, Oregon.

Holmberg, G.S., R.S. Shively, H.C. Hansel, T.L. Martinelli, M.B. Sheer, J.M. Hardiman, B.D. Liedtke, L.S. Blythe, and T.P. Poe. 1996. Movement, Distribution, and Behavior of Radio-Tagged Juvenile Chinook Salmon in John Day, The Dalles, and Bonneville Dam Forebays, 1996. Annual Report by the U.S. Geological Survey, Columbia River Research Laboratory, Cook, Washington for the U.S. Army Engineer District, Portland, Oregon.

Moursund, R.A. K.D. Ham, P.S. Titzler. 2003. Hydroacoustic Evaluation of Downstream Fish Passage at John Day Dam in 2002. PNWD-3236, Final Report by the Pacific Northwest National Laboratory, Richland, Washington, for the U.S. Army Corps of Engineers District, Portland, Oregon.

NOAA Fisheries (National Marine Fisheries Service). 2000. Biological Opinion. Reinitiation of Consultation of the Federal Columbia River Power System, including the Juvenile Fish Transportation Program and 19 Bureau of Reclamation Projects in Columbia Basin. National Oceanic and Atmospheric Administration National Marine Fisheries Service, Seattle, Washington.

Ploskey, G.R., C.R. Schilt, M.E. Hanks, P.N. Johnson, J.R. Skalski, W.T. Nagy, P.N. Johnson, D.S. Patterson, J. Kim, and L. Lawrence. 2002a. Hydroacoustic Evaluation of Fish Passage through Bonneville Dam in 2000. Technical Report ERDC/ELTR-02-8 of the U.S. Army Engineer Research and Development Center, Waterways Experiment Station, Vicksburg, Mississippi.

Ploskey, G.R., C.R. Schilt, M.E. Hanks, P. N. Johnson, J. Kim, J.R. Skalski, D.S. Patterson, W.T. Nagy, and L.R. Lawrence. 2002b Hydroacoustic Evaluation of Fish-Passage Efficiency at Bonneville Dam in 2001. PNNL-14047, Final Report by the Pacific Northwest National Laboratory, Richland, Washington, for the U.S. Army Corps of Engineers District, Portland, Oregon. 
Ploskey, G.R., C.R. Schilt, J. Kim, C.W. Escher, and J.R. Skalski. 2003. Hydroacoustic Evaluation of Fish Passage through Bonneville Dam in 2002. Final Report PNNL-14356, prepared by the Pacific Northwest National Laboratory, Richland, Washington, for the U.S. Army Corps of Engineers District, Portland, Oregon.

Ploskey, G.R., M.A. Weiland, C.R. Schilt, J. Kim, P.N. Johnson, M.E. Hanks, D.S. Patterson, J.R. Skalski, and J.B. Hedgepeth. 2005. Hydroacoustic Evaluation of Fish Passage through Bonneville Dam in 2004. Technical Report PNNL-15249 prepared by the Pacific Northwest National Laboratory, Richland, Washington, for the U.S. Army Corps of Engineers, Portland District, Portland, Oregon.

Ploskey, G.R., M.A. Weiland, S.A. Zimmerman, J.S. Hughes, K. Bouchard, E.S. Fischer, C.R. Schilt, M. . Hanks, J. Kim, J. R. Skalski, J. Hedgepeth, and W. T. Nagy. 2006. Hydroacoustic Evaluation of Fish Passage through Bonneville Dam in 2005. PNNL-15944 prepared by the Pacific Northwest National Laboratory, Richland, Washington, for the U.S. Army Corps of Engineers District, Portland, Oregon.

Reservoir Control Center. 2000. Fish Passage Plan for 2000 Corps of Engineers Projects. U.S. Army Corps of Engineers, North Pacific Division, Portland, Oregon.

Reservoir Control Center. 2001. Fish Passage Plan for 2001 Corps of Engineers Projects. U.S. Army Corps of Engineers, North Pacific Division, Portland, Oregon. 